\title{
ISSUES OF DANCE NOTATION: DOMENICO DA PIACENZA'S DANCE WRITING IN FIFTEENTH-CENTURY ITALY
}

\author{
By \\ Chloe Spedding
}

\begin{abstract}
A thesis
submitted to the Victoria University of Wellington in fulfilment of the requirements for the degree of Master of Arts in Italian
\end{abstract}

Victoria University of Wellington 2013 


\section{Abstract}

Dance is an art form that is traditionally taught through physical demonstration.

Choreography is forgotten if it is not practised repetitively, as dancers must rely on physical memory without the help of a written score to remind them of the steps. So many great works have been lost over time as choreographers have neglected to preserve their routines in written form. To prevent this, multiple notation systems have been created but none of them have ever become as popular or standardised as music notation. Many of these systems involve symbols that can only be understood by those who have studied the system in depth and are therefore inaccessible to the everyday dancer or choreographer.

The origins of dance notation in Western culture come from fifteenth-century Italy. Dance masters who served at the many courts of the country recognised the need for dance to be intellectually understood as well as performed. The popularity of manuals as a way to discuss art, music, philosophy and many other subjects that formed the education of the elite during the Renaissance led to the writing of dance manuals. Domenico da Piacenza (c.1400-1476) was the first to do this, and his treatise De arte saltandi et choreas ducendi (c.1455) is an eloquently written model text for all dance manuals that followed.

Domenico does not notate his dances with symbols, but rather uses word descriptions to explain his choreography. His manual includes sixteen chapters which discuss the qualities one should aspire to achieve when dancing, the nature of the different misure (speeds) of the music, and how one should dance to each of these. This is followed by descriptions of eighteen of Domenico's balli accompanied with his self-composed music, and five bassadanze. 
By examining closely three of Domenico's balli, and attempting to reconstruct them, this thesis engages with issues regarding the preservation of dance and how effective the use of the written word is for doing so. Although there are several flaws in Domenico's system, the idea of using the written word to notate dance still seems the most practical to date. The method created by Domenico in fifteenthcentury Italy for his court dances is still the most common way for modern dance forms such as ballet and ballroom to be notated, transmitted to others and learned by dancers today. 


\section{Acknowledgements}

To begin with I would like to thank Jennifer Shennan for introducing me to Domenico's world and works. Without her teaching I would not have come across Domenico's choreographies and would not have written this thesis. Jennifer, along with Keith McEwing also ran community classes in Renaissance dance, allowing me to practise some of Domenico and his contemporaries' routines. Keith was also a great help in recommending secondary sources and lending me his collection of texts.

I also need to acknowledge my senior dance students who acted as my guinea pigs as I tried to figure out what Domenico intended when he wrote his instructions. They were patient as I pushed them in different places around the room, and willing to learn and perform multiple versions of one routine as I tried to figure out whose interpretation seemed most likely to be true. It is near impossible to figure out routines designed for several people when you are by yourself, so I owe a lot to Abby Burdis, Phoebe Christensen, Jessica Fulton, Susie Harcourt, Aimee Law and Jessica Ryan.

Finally, I would like to thank my supervisor Dr. Claudia Bernardi who has been an immense help and a steady presence throughout my study this past year. 


\section{Table of Contents}

Table of Illustrations

Introduction

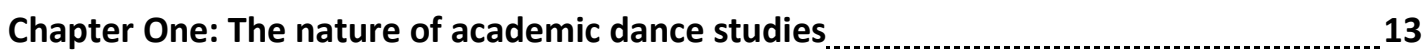

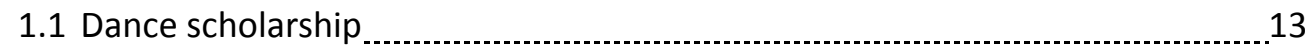

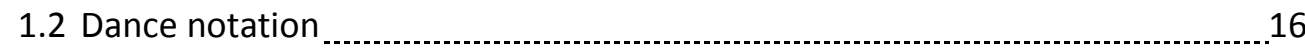

1.3 An overview of some notation systems $\ldots$

Chapter Two: Domenico da Piacenza and the role of dance in fifteenth-century Italy .....29

2.1 Historical context

2.2 Domenico

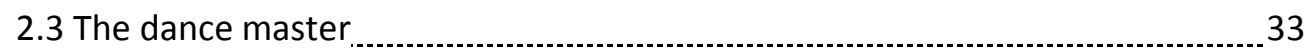

2.4 An activity for the elite $\ldots$

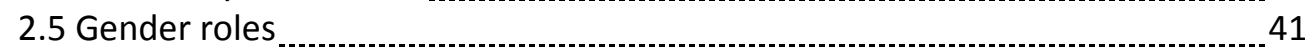

2.6 Philosophy and the aesthetics of dance

2.7 Music and dance

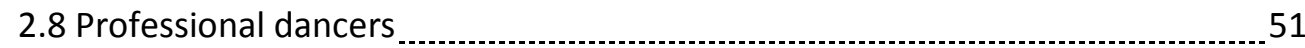

2.9 Conclusion

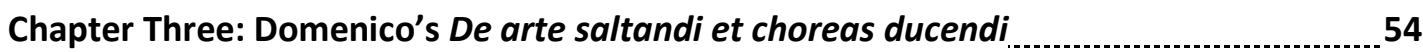

3.1 The culture of writing manuals

3.2 The original manual

3.3 The aesthetics of dance

3.4 The four "misure"

3.5 The language of dance

3.6 Classical references

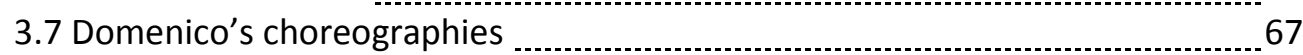

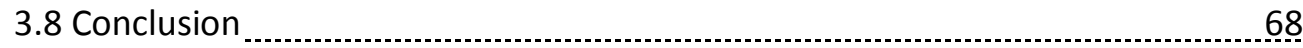

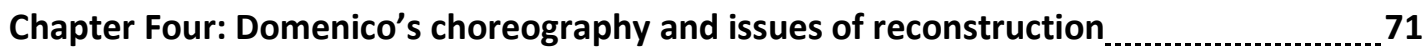

4.1 Introduction $\ldots$

4.2 The ballo Anello

4.2.2 The problems in reconstructing Anello .......................................... 76

4.2.3 Concluding remarks on the difficulty in reconstructing Anello ..........8 84

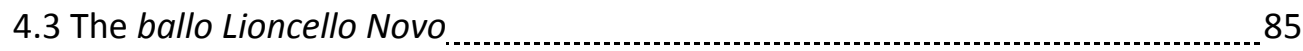

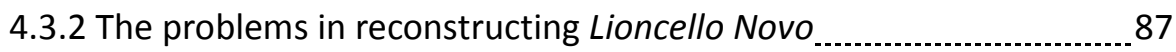

4.3.4 Concluding remarks on the difficulty in reconstructing Lioncello Novo

4.4 The ballo Gelosia

4.4.2 The problems in reconstructing Gelosia

4.4.1 Concluding remarks on the difficulty in reconstructing Gelosia ........100

4.5 General conclusions

Conclusion: From textual analysis to performance

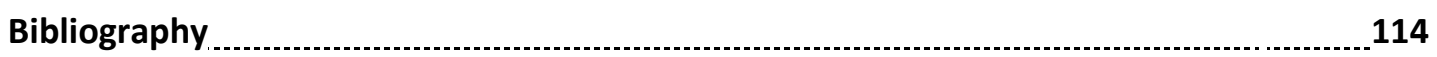

Appendix 


\section{$\underline{\text { Table of Illustrations }}$}

Fig 1: The Golden Manuscript, c.1460, Brüssel, Bibliothèque Royale Albert I., Ms. 9085, Flanders. [http://www.nlr.ru/eng/coll/music/facs.html?print=1; accessed 27/3/12.]

Fig 2: Excerpt from Arbeau's manual Orchésographie,1588, instructing the reader on how to perform a reverence.

[http://avaxhome.ws/ebooks/others/thoinot_arbeau_-_orchesographie.html; acessed 2/4/12.]

Fig 3: Choreography from Orchésographie, 1588, Thoinot Arbeau's manual. [http://www.peterdur.us/kwds2007/proceedings/Survey-of-European-DanceSources.htm; accessed 2/4/12.]

Fig 4: The Rose pattern, an illustrated floor plan from Fabritio Caroso's Nobilità di dame. [http://teresaleedesign.com/balletwonderland/floorplans_1.html; accessed 2/4/12.]

Fig 5: A Baroque Dance notated in the Feuillet system, 1713. [http://m.eb.com/assembly/71979; accessed 2/4/12.]

Fig 6: The symbols that represent each part of the body in Labanotation. [http://en.wikipedia.org/wiki/Laban_Movement_Analysis; accessed 2/4/12.]

Fig 7: The symbols used to represent direction and level of steps in Labanotation. [http://ajijo.co.uk/labanot.html; accessed 2/4/12.]

Fig 8: A ballet exercise notated in Labanotation. [http://www.balletdance.com/200607/articles/Rathvon20060324.html; accessed 24/4/12.]

Fig 9: An example of choreography written in the Benesh notation system. [http://onensemble.org/2010/08/book-reviews-dance-notation/; accessed 2/4/12.]

Fig 10: Monthly salaries of musicians and others of the Borso d'Este Court of Ferrara, 1456. Sparti, Barbara. "The Function and Status of Dance in FifteenthCentury Italian Courts." Dance Research: The Journal of the Society for Dance Research, Vol. 14, No.1. (46).

Fig 11: Allegoria degli Effetti del Buon Governo in Città. Right wall, Sala dei Nove, Palazzo Pubblico, Siena. Ambrogio Lorenzetti, 1338-1339. [http://mydailyartdisplay.wordpress.com/2011/02/13/effect-of-good-governmenton-city-and-count; accessed 26/6/11.]

Fig 12: Part of the notated music for Re di Spagna and il Ferrarese. From Cornazano's Libro dell'arte del danzare. Città del Vaticano, Biblioteca Apostolica Vaticana, Cod. Capponiano 203, c. 28v [lines 964-85]. William Smith, A. Fifteenth- 
Century Dance and Music. Vol. I: Treatises and Music. (New York: Pendragon Press, 1995), 211.

Fig 13: Bassadanza. Fifteenth-century miniature.

[http://bibliolore.org/2010/07/04/basse-danse-with-attitude/; accessed 26/6/11.]

Fig 14: Court people performing a dance in a circle. $15^{\text {th }}$ century book illustration. [http://www.earlydancecircle.co.uk/three.html; accessed 9/9/11.]

Fig 15: A painted miniature of a ballo for three from Guglielmo's De pratica seu arte tripudii. 1463. Paris, Bibliothèque nationale, f. Ital. 973, c. 21v (between lines 1134 and 1135). [http://www.balletto.net/giornale.php?articolo=1034; accessed 26/6/11.]

Fig 16: Notation of the ballo Verçeppe from Domenico's De arte saltandi et choreas ducendi. Paris, Bibliothèque Nationale, f. Ital. 972, c. 13r, [lines 652-64]. William Smith, A. Fifteenth-Century Dance and Music. Vol. I. Treatises and Music. (New York: Pendragon Press, 1995) 7.

Fig 17: Diagram of the misure from Domenico's De arte saltandi et choreas ducendi. Bibliothèque Nationale, f. Ital. 972, c. 4v, [lines 201-25]. William Smith, A. FifteenthCentury Dance and Music. Vol. I: Treatises and Music. (New York: Pendragon Press, 1995) 4.

Fig 18: Notation of the ballo "Anello" from Domenico's De arte saltandi et choreas ducendi. Paris, Bibliothèque Nationale.

[http://www.compagniadeiviandanti.it/images/Approfondimenti/De\%20arte\%20sal tandi\%20et\%20choreas\%20ducendi.png; accessed 28/8/11.]

Fig 19: Illustrations from Carlo Blasis' Traité élémentaire, théorique, et pratique de l'art de la danse, 1820.

[http://www.lib.utah.edu/collections/rarebooks/exhibits/past/dramatispersonae.php; accessed 17/11/12.]

Fig 20: Part of the Labanotation for Doris Humphrey's work "Two Ecstatic Themes". [http://www.ballet-dance.com/200607/articles/Rathvon20060324.html; accessed 26/10/12.]

Fig 21: A photograph of a rehearsal of Broadway show Kiss Me, Kate. The dancer in front reads from the Labanotation score.

[http://www.dancemagazine.com/blogs/admin-admin/4463; accessed 26/10/12.] 


\section{Introduction}

In 2007 I studied for a paper at Victoria University of Wellington entitled "Dances in History". I had a strong background in dance, having learned tap, jazz and ballet throughout my school years, sitting exams, participating in competitions and, while in high school, teaching classes in all three disciplines. Therefore I had a reasonably sound knowledge of the modern dance world, but knew nothing of how it came about and what dance forms preceded it. The "Dances in History" course was a true eye-opener for me, introducing me to dances from the Middle Ages, the Renaissance, the Baroque and the nineteenth century, providing insight into how dance has developed over time.

The paper also introduced me to the idea of dance notation, as the course outlined Domenico da Piacenza's manual, the Feuillet system, Labanotation and other forms of dance writing. This is an idea that has always fascinated me. As a dance teacher I have often struggled to find an appropriate way to notate dances, either for my own preservation purposes, or as a way for students to remember their routines. Thus I was inspired to do some research into this field of study and discover how others throughout history have done it. Unfortunately for me, Dance Studies was cancelled at Victoria University in 2008 , so I did not have the chance to further this study in my undergraduate programme and I pursued a Bachelor of Arts in Italian, Classical Studies and English Studies instead.

When it came to writing an MA thesis, the idea of linking Italy and Dance, two of my favourite subjects together in one paper appeared very appealing to me. As I had learned that the first person to write down dance in Western culture was an Italian, I decided his work would be the perfect place to begin. This way I could research Renaissance Italy, the role of dance in that society, how dance writing came about and how effective the original system of writing was in comparison to other subsequent methods of preserving dance. 
This Italian who first took the initiative to write down his choreography was named Domenico da Piacenza and taught dance to members of powerful Renaissance courts in different parts of Northern Italy. In the middle of the fifteenth century he wrote a manual entitled De arte saltandi et choreas ducendi which consists of sixteen chapters about the aesthetics of dance followed by instructions for twentythree of his own choreographies. It was written in Italian, albeit an archaic Italian which is difficult for even a native speaker to read today. The original manual is now housed in Paris at the Bibliothéque Nationale. It does not seem to be written in Domenico's own hand, but rather that of up to six scribes, as I will discuss further in Chapter Three.

In my thesis I aim to find out who Domenico da Piacenza was by establishing his status within society, his role as dance master, his initiative as dance writer and the effect his work had on those who came after him. I intend to set the context by framing my research within the society Domenico was living in: who was he teaching? For whom was he choreographing and writing his manual? Why did he decide to write down his choreography and why did he include instructions on technique alongside this choreography? I then examine the manual itself and describe the technique, style and choreographies of fifteenth-century court dance.

Dance history is not yet a wide field of scholarship. Upon researching, I discovered there is not an abundance of available material; however there is enough to support my investigation. Domenico da Piacenza is mentioned in many of the available texts regarding dance notation and dance history. In most circumstances, however, he appears as a brief mention giving him credit as the first person in the Western world to write down choreography. A few dance historians have specialized in Renaissance court dance, such as Barbara Sparti, A. William Smith and D. R Wilson, whose works I discuss thoroughly to support my thesis. Other specialists, such as Ann Hutchinson Guest, are leading scholars in dance notation; I lean on her research to support the theoretical framework to my analysis. 
Before I look at Domenico da Piacenza, his manual and the society he lived in, I carry out a preliminary survey of the world of dance scholarship and dance notation in order to establish the theoretical debate behind these two fields necessary to my discussion. After this section comes an assessment of fifteenth-century Italy, the role of dance within society and the status of a maestro di ballo such as Domenico da Piacenza, and a brief summary of the humanist philosophy of the time that may have influenced Domenico's writing. Following that, I address the question of how effective Domenico's dance-writing system was and whether it is still possible today to reconstruct choreography that was written down five and a half centuries ago. I do this by examining the manual, learning the style of dance and attempting to perform some of Domenico's choreography.

Chapter One is a brief outline of how dance stands as an academic subject, why it is important to study dance and how scholars go about their research. Dance is compared to other arts such as theatre, painting, film and music, and the questions of why other arts are studied more in depth and more often and why they have a longer or more thorough written history than dance are addressed. The chapter explores the idea of dance notation and why it is important to preserve choreography in a written form. To illustrate this discussion, I provide examples of some of the many different systems that have been developed throughout history, such as the Feuillet System, Labanotation and the Benesh Notation System, in order to compare them to Domenico's own method. I also compare the favoured modern way of preserving dance by use of video recording and point out reasons why a written text may be more reliable. Ann Hutchinson Guest's book Dance Notation: The Process of Recording Movement on Paper is a major source for the discussion in this chapter. She is considered a world authority on dance notation, particularly on Labanotation, and in this study she discusses all known dance notation systems in the Western tradition.

In Chapter Two, the focus is on fifteenth-century Italy. I look at who Domenico da Piacenza was, who he was working for and more hypotheses as to why dance writing came about in this specific historical moment and geographical location. I 
discuss in particular the role of dance within the Renaissance courts and who performed Domenico's choreographies and for what occasions or purposes. Gender roles are also taken into account, and I note that dancing is one of the few areas of Italian Renaissance society in which women were allowed to participate and play a dominant role. I compare the style of Domenico's choreography as written in his manual to that of the moresche that were danced by professional dancers; thus I establish that whilst these performances were mentioned in many town records and personal diaries, the actual choreography was very rarely written down, unlike the court dances that were notated in manuals such as Domenico's. I also look at the culture of writing manuals in Renaissance Italy in order to establish how the humanist philosophy of the period may have affected Domenico's decision to write a manual on dance and influenced the style in which he wrote it.

This section on fifteenth-century Italy could rely on more existing literature than any of the other sections, as social historians, art historians and musicologists have also focussed on the role of dance in the Renaissance alongside dance historians, as it played such a prominent part in society: by understanding dance these historians are able to understand better their own area of interest. The work of Italian dance historians Alessandro Pontremoli and Barbara Sparti plays a large supporting role in this chapter, as does that of Australian musicologist Jennifer Nevile.

Once the background of dance scholarship and dance notation are established and the context of fifteenth-century Italian society is recognised, I can turn to the manual itself. Chapter Three is a detailed examination of De arte saltandi et choreas ducendi, the manual that Domenico da Piacenza wrote c.1455. It will mainly focus on the sixteen chapters that precede the written choreographies. These chapters are a discussion of the aesthetics of dance: Domenico instructs his readers on important techniques and qualities one should strive to achieve when dancing. He emphasises the importance of understanding music and concentrates on the different misure in the repertoire of Italian court dance and how one should best dance to each speed. 
A. William Smith provides an excellent transcription and translation of Domenico's manual in his text Fifteenth Century Dance and Music. As I do not have access to the original manual housed in the Bibliothéque Nationale in Paris, it is on this copy of the manual that I base my discussion in Chapter Three. From the examination of this copy of the manual, I illustrate the style of Domenico's court dance before I attempt to reconstruct some of his choreographies.

The reconstruction comes in Chapter Four, when I present three dances that I then attempt to perform. I read Domenico's instructions carefully and note any issues I have with his written description. These issues range from not knowing how to perform the steps, to floor pattern discrepancies, to ambiguous descriptions making it unclear as to what Domenico intended his readers to perform. I then address these issues and see if it is still possible to recreate choreographies that are more than 500 years old. A video demonstration of steps and of three choreographies (Anello, Lioncello Novo and Gelosia) is included as an appendix to support the textual analysis. Madeleine Inglehearn and D. R Wilson's works heavily influence this chapter. Both these scholars have done major research into how fifteenth-century Italian court dance should be performed and their ideas form the base for my discussion of the three dances I have chosen to reconstruct. By the end of my thesis, I hope to have established how effective Domenico's writing system was in preserving dance for posterity, why he wrote it, how he did it, whether and to what extent it can still be considered a valid method to notate dance today. 


\section{Chapter One: the nature of academic dance studies}

\subsection{Dance scholarship}

Before directly examining the life and legacy of Domenico da Piacenza it is important to develop an understanding of what dance scholarship is. Who studies dance and to what extent? What is the focus of dance research and what have scholars already discovered? Does dance have a history of its written form as well as of its physical and theoretical aspects? What is the relationship between text and movement? Does dance have the same status as other arts? These are some of the questions that I will address in this chapter in order to set my discussion of dance writing in fifteenth-century Italy within the wider context of the history of dance scholarship.

When it comes to the arts in the Western tradition, most of the individual disciplines can be traced as far back as the Ancient World. Artists can look back to tomb paintings, architects can study the Parthenon, sculptors can examine the works of Myron, poets can read Homer. By contrast, due to its ephemeral nature, dance from the classical period does not exist in a form one can study and recreate today (Herbison-Evans 1998, 45). Because of the lack of historical sources, dance scholarship is not yet a wide field of research. Much of the existing research is about XX century dance, when videos, photographs, personal interviews, memoirs and repeated performances made dance easier to study. Barbara Sparti points out that this has produced "students who know - and care - little or nothing about what came before", often due to the fact that their supervisors and lecturers do not know a great deal on the subject, so instruct them to avoid it (Sparti and AdsheadLandsdale 1996, 3). Additionally, this means that dance history is viewed with skepticism by many scholars of other disciplines as it is still a relatively new academic discipline. Although the practice of dance is an age-old activity, written study of it is a recent development. It is interesting to compare this to film, where the circumstances are reversed: the art of cinema itself is a relatively new creation and yet academic studies of the subject are both numerous and taken seriously. 
Both dance and film are visual texts, so what makes one art, even if it is much more recent, seemingly easier to study than the other which has a longer history? The answer is obvious: a film is more accessible, it has a tangible, permanent text that can be watched multiple times; conversely, a dance (historically) lives on only in the mind of the performers and choreographers, and perhaps very astute audience members. The invention of film has meant that dance may be videoed and documented, and so can potentially be studied in the same manner as film. However, this has its limitations, as I will discuss below, and is not applicable to pretwentieth-century dance.

Thus, it is necessary to turn to written records to obtain information about the nature of dance from earlier times and to attempt to reconstruct particular choreographies. As I said in the introduction, the earliest work that tries to document dances and choreography is a manual written c. $1455^{1}$ by Italian dance master Domenico da Piacenza, titled De arte saltandi et choreas ducendi, followed immediately by those of his loyal students Antonio Cornazano (Libro dell'arte del danzare, 1455) and Guglielmo Ebreo (De pratica seu arte tripudii, c.1463), who were inspired by Domenico's efforts to continue the distribution of this specialist knowledge.

Although the Italian Renaissance was a very significant time in the history of dance, as we will see in Chapter Two, there is not a great deal of research done on the subject. Academic research on fifteenth-century dance did not begin until 1873, more than 400 years later, when Francesco Zambrini published a transcription of a dance manual written c.1463 by Giovanni Ambrosio (also known as Guglielmo Ebreo), a student of Domenico da Piacenza (Smith 1995, Vol.1, 7). Claudia Celi believes that historical documents in Italian libraries, archives and collections that may relate directly or indirectly to dance have only been partially explored (Celi 2004a, 553); but in the documents that have been investigated thus far, references to dancing are thin (Sparti 1996b, 43). Dancing was such a common, everyday

\footnotetext{
${ }^{1}$ The exact date is unknown, but 1455 is assumed by many scholars to be the more likely date, as I will discuss in detail in Chapter 3.
} 
activity in Renaissance Italy that nobody found it necessary to write about it in great detail. Sparti highlights vague references found in historical documents, such as "accompagnorono suso la sala grande, et ivi ballato per spazio de due hore" or "e ritornati a la Corte, se feceno molte danze fino a nocte" (Sparti 2001, 297). Mostly we are told who danced with whom at some festive events. Such references do not occur very often, and when they do, they seem more an indication of hierarchy and power, rather than pertaining to the dance itself (Sparti 1996b, 43).

This absence of detail is perhaps a reason why there is not an abundance of academic dance study, compared to other arts. Dance as a field of scholarship is relatively new. Although it has been studied within the context of other subjects, such as musicology, art history and social history, dance history in its pure form is somewhat under studied. Academic research with dance as its primary focus has been developed only in approximately the last 20 years (Nevile 2004, 4). Italy has been a fore-runner in dance theory and practice for centuries, with its Renaissance dance-masters laying the foundations for dance composition and notation as we know it today, yet it was not a subject one could earn a degree in at an Italian university until the early 1990s (Veroli and Sparti 1995, 73). The Università di Bologna seems to be the first to offer a dance history course, albeit only temporarily, in 1992-3, entitled "History of Mime and Dance" (Celi 2004a, 554). Aside from this course, the only academic recognition received by dance in Italian universities has been through the writing of dissertations on dance history by a relatively small number of students (Celi 2004a, 554). Perhaps this lack of study is responsible, at least in part, for the limited awareness of dance notation, which is the term scholars use for the act of transcribing dance.

Now, five and a half centuries after Domenico wrote his manual, dance notation is still considered a relatively new idea (Guest 1984, xi). In fact, choreography is still often referred to as "the throwaway art" because of the large number of dance productions and ballets that have been forgotten because they were never written down (Guest 1984, xi). Today, The Rite of Spring is known by most as a musical work, but originally it was a ballet too, created together by composer Igor Stravinsky and 
dancer/choreographer Vaslav Nijinsky in 1913. This is one of the many lost ballets: nothing was written down at a time that preceded video/film recording, and since Nijinsky became insane soon after its first performance, the choreography was never performed again (Herbison-Evans 1988, 45). It is such a shame to lose great pieces of art just because dance, unlike painting, theatre, literature or music, is something physical and ephemeral, created by the body, and not fixed on page or canvas. It seems therefore sensible to write down dance, to preserve it and teach it to others. But to what extent can this be accomplished?

\subsection{Dance notation}

The word "choreography" comes from the Greek choros (dancing) and graphie (writing) (Franko 2011, 321). If the word itself combines "dancing" and "writing", why does the idea of combining the two in practical application seem absurd or unnecessary, or just plain daunting to much of the dancing community? Dance notation has been attempted in about eighty five different ways since the fifteenth century (Guest 1984, xi), yet it remains an unknown concept to the majority of dancers and choreographers (Franko 2011, 327-28). Dance is still largely taught through oral instruction and physical demonstration. Unlike music, there is no one system that has been developed and standardized world-wide, or used for teaching the art. Why is this the case? Why is a dance notation system so much more difficult to create and teach than a music notation system? As Marko Franko points out, surely both arts would encounter the same problems with their notation systems: it is difficult to know from a performance if what performers do is an exact representation of the notation, due to different possible interpretations, performance styles, levels of technique, and of course whether they make mistakes or not (Franko 2011, 329). So why is there one universally known music notation system, but multiple, scarcely known dance notation systems? Why does notation work successfully for one art and not for the other?

Before we examine this issue, Anne Hutchinson Guest's definition of dance notation will help us to frame the discussion: 
The process of dance notation requires reducing four-dimensional movement (time being the fourth dimension) to a two-dimensional surface. The parts of the body in action have to be defined, as does the form of movement involved (flexion, extension, rotation, directional placement) and the duration of each in relation to the overall time structure. In group dances the relationship of dancers to one another must be determined and recorded, as well as their location on stage and their paths of travel (Guest 1984, 203).

Guest is a firm believer that "[d]ance notation is (or should be) to dance what music notation is to music and the written word to drama" (Guest 1984, xiv). Playwrights and theatre directors do not teach their cast a play by telling them the lines and expecting them to remember them simply by having heard them, and a conductor or composer does not teach an orchestra a new piece by humming each part to the relevant musicians (Guest 1984, 2). In both situations, a written form is used so that the performers can learn their parts by reading them. Why should this be different for dance? The common method of teaching dance by using verbal instructions and physical demonstrations has resulted in works such as major classical ballets being passed down like Chinese whispers - varied a little each time they are re-taught (Guest 1984, 1). If choreographers and teachers wrote down their work and ideas on technique, just as Domenico did, then many more people could benefit from their knowledge, not just the students or performers that work directly with them.

Writing is an important tool for transmission of knowledge. If we examine why it is used, we can conclude that it is a superb way to record information, whether it be to teach people about a particular topic, clarify ideas, preserve works, learn something intellectually rather than just physically, or make something official by putting it on paper (Tembeck 1981/82, 68). All of these circumstances can be applied to dance. Domenico's De arte saltandi et choreas ducendi was written for (and achieves) all of these purposes: to teach the elite class of Italian society, clarify ideas about etiquette and technique, to preserve his choreographies, to articulate and learn something usually just physical from an intellectual perspective and to make something official. Domenico strove to make dance an art and a science by putting it down on paper. 
Domenico's method of dance writing was simple. By including chapters on theory, his readers were informed on how to dance before the choreographies themselves were included. These dances were notated by word descriptions and, on most occasions, accompanied with the music. This is the same way many dance forms, such as ballet or ballroom, are taught today. Books describe the theory of the dance form and syllabuses include word descriptions of exercises and routines. However, many dance theorists have found this method of transcribing dance with words unsuitable, and have created more visual forms of dance notation, some of which will be described later in the chapter.

Other dance teachers and choreographers do not use notation at all, but rather turn to a more modern approach. In today's technological age, a popular way of recording and preserving dances is achieved by video. This can be helpful, but some scholars point out that it is still not ideal. For example, in 1988 Don Herbison-Evans' identified a number of problems that may arise from the use of video recording (Herbison-Evans 1988, 45-46). In his opinion, a major problem is that the viewer can only watch the dance from the angle it was videoed; we either need to translate each of the movements into mirror images when learning them off the video, or, if the dance is videoed from the back, assume what the front of the body is doing. The limits of a video camera are highlighted particularly in group numbers, where details might be missed, as some dancers might be hidden from the camera. Herbison-Evans pointed out that another interesting issue to consider when reconstructing a dance from video is whether what we see is what the choreographer initially intended, or whether it is the stylistic interpretation of the dancer. The final problem with using video to record dance concerns technology, as some cameras may not be of high enough quality to show clear definition of particular movements (Herbison-Evans 1988, 46).

Some of these problems can now be avoided, as technology has been developed over the past two decades and is now capable of achieving a higher degree of quality, however this brings up another issue: technology is forever being upgraded. The video tapes, or more to the point, the machines that play them, that Herbison- 
Evans was discussing in the late 80 s are now almost obsolete. Instead we have DVDs and blu-ray players, or just slip a disc into our computers. In another 20 years we may not be able to play them anymore either. Therefore, video recording may be an easy temporary way to record dance, but written notation appears to be able to withstand time better. Domenico's written word descriptions have survived five and a half centuries: we do not yet know whether a video recording made today will still be able to be played after that much time has passed. In any case, videorecording is only a very recent development in the history of dance, and is not relevant, to the preservation of the fifteenth century style that I am discussing here.

Dance notation does not present technological issues or problems with hidden movement and missing details. However, it is not without problems of its own. Herbison-Evans lists the main limits of dance notation. These include the difficulty of writing a score, from the complex symbols involved in some systems that require careful drawing (and often re-drawing for a final copy) to issues related to the time necessary for writing; one cannot notate a dance in real time, and if changes have to be made, a notator often has to start again from the beginning (Herbison-Evans $1988,47)$. Guest believes that to become a notator in any system requires two years of study in order to become fluent and fast enough, and a strong background in movement is also necessary (Guest 1984, 29). Thus, it is not easy to learn and implement a system, which leads to what is perhaps the biggest problem with dance notation: limited awareness. Many dancers simply cannot read dance notation and many choreographers cannot write it (Herbison-Evans 1988, 47). Tembeck points out that even if a dancer can read a notated score, he/she should still communicate directly with the choreographer to understand all the details (Tembeck 1981/82, 67).

Thus it seems that neither video nor dance notation are ideal ways to preserve dance: both present their own set of problems. However, of these problems, those to do with dance notation are apparently easier to overcome. While the problems with video derive from technology and its limits, the problems with dance notation 
depend on limited awareness and competence in the notation system itself. With time and practise these problems could be overcome.

When I discuss these problematic dance notation systems, I am referring to those that involve a set of symbols that represent movements. There is an alternative way to notate dance, and that is precisely Domenico's method of writing word descriptions of steps and choreographies. It is not a system without flaws. If it were, many others would have seen no reason to develop their own systems. However, it still seems to be the most accessible way to notate dance: the easiest to write and the easiest to read. By examining other notation systems, it will become obvious as to why this is the case.

\subsection{An overview of some notation systems}

The scope of this thesis does not allow me to present a detailed analysis of all dance notation systems created in the history of dance. Instead I will examine a selection of the most important systems in order to provide a basis for comparison with Domenico's own notation methods.

Soon after Domenico wrote down his dances, others started to do so too. Many chose to create notations that replaced Domenico's more traditional writing style with symbols or visual systems that could be used specifically for dance recording. Below is one of the earliest known systems, dating back to c.1460. Its creator is unknown, and so unlike many other systems it is not named after a specific person. This manuscript is the most spectacular example of its kind, often called the "Golden Manuscript", due to the fact the dance is written on a black background in gold and silver. It is also referred to as the "Burgundian Manuscript" as it originally belonged to Marie de Bourgogne, or "The Dance Book of Margaret of Austria", as Marie handed it down to her daughter Margaret (Guest 1984, 44). 


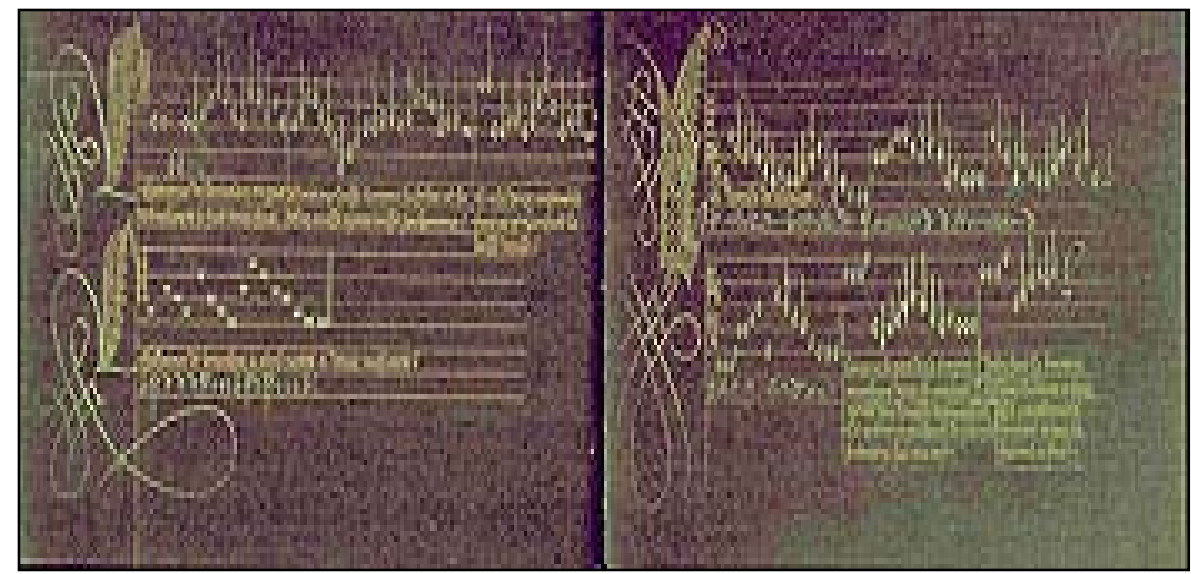

Fig.1 The Golden Manuscript, c. $1460{ }^{2}$

In Renaissance France and Burgundy there were five main movements a dancer was expected to perform, and in the notation system these movements were represented by a letter. ' $R$ ' for révérence, 's' for simple, ' $d$ ' for double, ' $b$ ' for branle and ' $r$ ' for reprise (Guest 1984, 44). Some choreographers still notate their dances today by abbreviating step names (Guest 1984,46$)$. These steps were very similar to the sempio, doppio, ripresa and riverenza that Domenico used in his choreographies. In 1588, over a century after Domenico's treatise was published, Thoinot Arbeau wrote a manual entitled Orchésographie. Set out as a dialogue between dance master and student, Arbeau's manual teaches the reader about social etiquette, music, dance steps and technique (just as Domenico did), as well as containing choreographies and pictures of how steps should be executed.

${ }^{2}$ All sources for illustrations are indicated in the Table of Illustrations (pp. 6-7). 


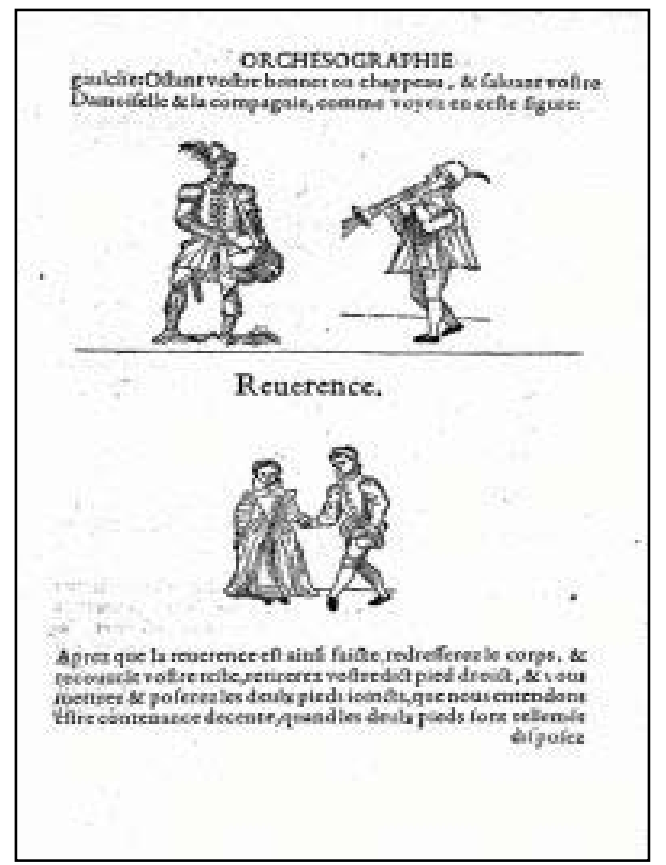

Fig 2. Excerpt from Arbeau's manual Orchésographie instructing the reader on how to perform a reverence.

Arbeau's choreographies were formatted as below, with the music tablature down the side of the page, and the steps named next to the bar of music they were to be performed in:

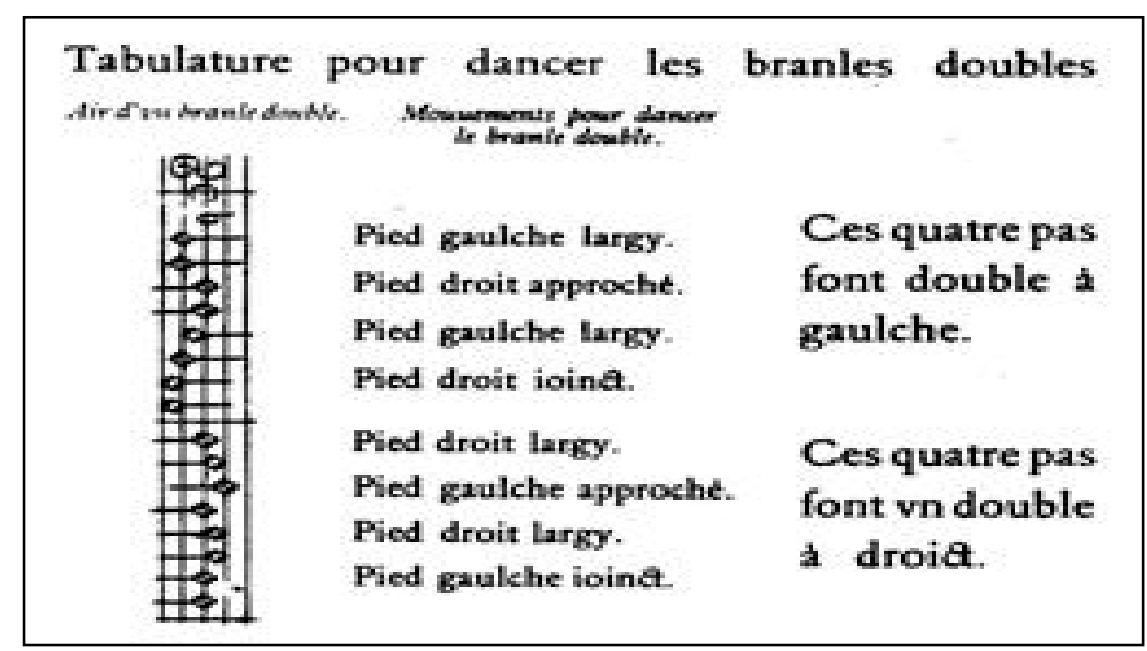

Fig 3: Choreography from Orchésographie, Thoinot Arbeau's manual. 
To return to Italy, the late Renaissance saw dance masters such as Fabritio Caroso and Cesare Negri at the top of the European dance chain. Their manuals were written in a similar manner to Domenico's, but more detailed and with illustrations. The most famous of these illustrations is the Rose Pattern, found in Caroso's Nobilità di dame, published in 1600 .

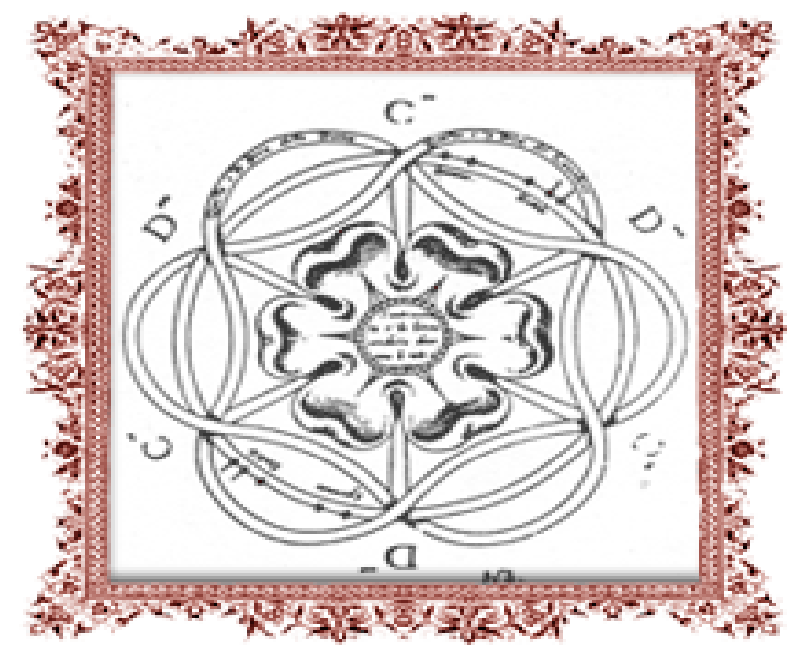

Fig 4: The Rose Pattern, an illustrated floor plan from Caroso's Nobilità di dame.

This illustration shows the floor pattern the dame and the cavalieri should take when performing "Contrapasso Nuovo". The illustration was titled "Il contrapasso fatto con vera mathematica sopra i versi d'Ovidio" (Sutton 2004, 242).

None of the systems mentioned so far were developed enough to show floor patterns, dance steps and musical timing all at the same time. It was not until the eighteenth century that this was achieved, with the Feuillet system. Although it was published by Raoul Auger Feuillet in 1700, it is presumed to have been developed by the renowned dance master Pierre Beauchamps, who was too slow to publish it and claim authorship (Guest 1984,63$)$. The system was so well-developed and so suitable for Baroque dance that it was used throughout Europe (Guest 1990, 206). In the Feuillet system, each dancer's path is set out and the steps are drawn on along that path. If a symbol is on the right side of the line, the right foot is to perform it, if it is on the left, the left is to perform it. A dash across the line of dance 
indicates the end of a musical bar line - this combined with the music tabulation written across the top makes it clear how the steps fit with the music. Different symbols represent different steps.

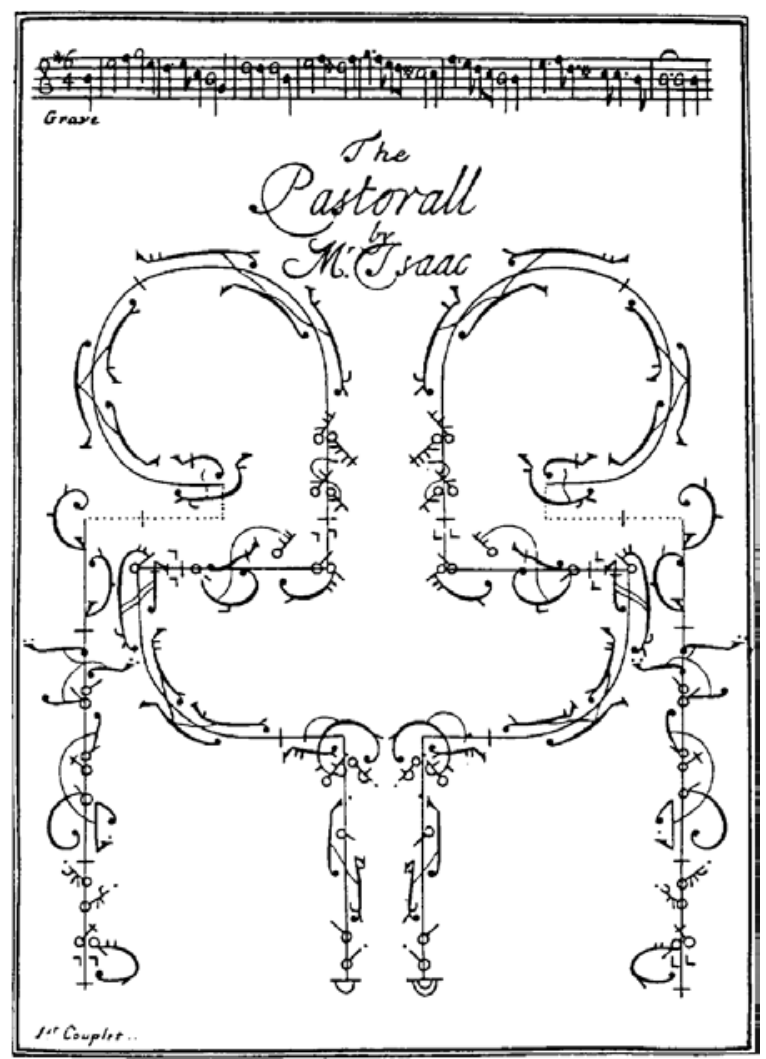

Fig 5: A Baroque dance notated in the Feuillet system

Unfortunately, the Feuillet system did not remain in use, and for good reasons. As dance steps and arm positions became more complex, and more than two people at a time performed dances, it became impossible to write these new dances in this form. Dance was also spreading to the general public, no longer a pastime for the elite only, therefore dance literacy was no longer a focus, as the lower classes were often not able to read the manuals (Guest 1984, 66-67).

The main systems in use today are Labanotation (or "kinetography", mostly used in Europe and the USA) and the Benesh system (or "choreology", used in the UK and Commonwealth countries) (Herbison-Evans 1988, 46). Laban is considered the "father of modern dance" in Europe, although his theories have not just benefitted the world of dance, but that of physiotherapy too (Guest 1990, 211). There are 
about 1500 different symbols in Labanotation (Herbison-Evans 1988, 46), that can be grouped into families. These symbols represent the different parts of the body to be used:

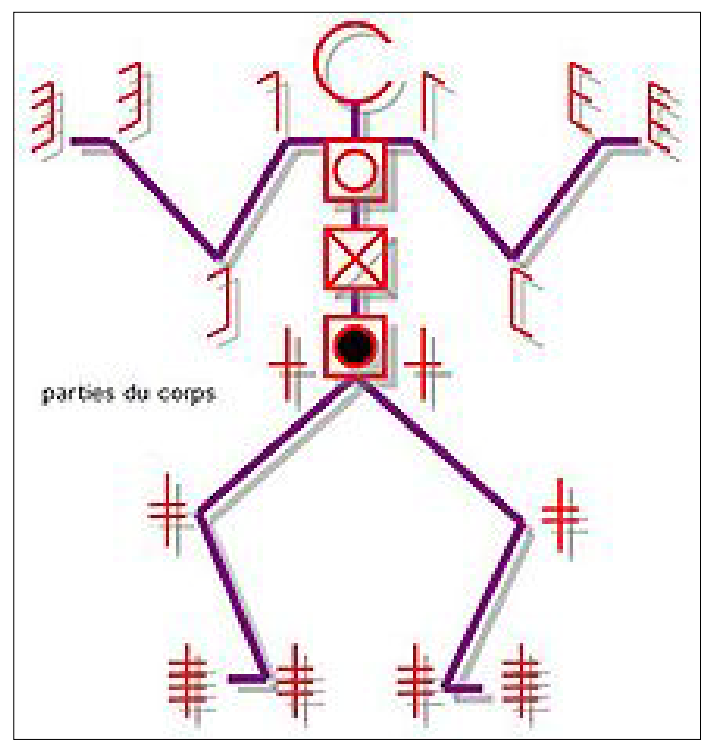

Fig 6: The symbols that represent each part of the body in Labanotation.

Labanotation also includes symbols that represent the direction of steps, and whether they are low, medium or high:

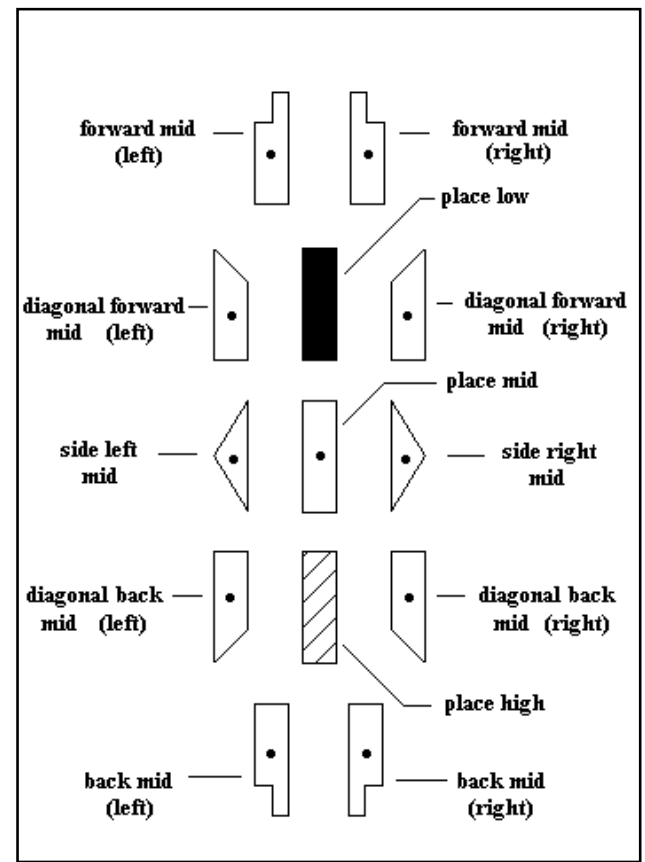

Fig 7: The symbols that represent direction and level of steps in Labanotation. 
The notation is read vertically, rather than horizontally as music is, and like the Feuillet system a line in the centre divides the right side from the left, while lines across the staff determine musical timing. Labanotation is the only system that combines timing, direction, level of the action and which part of the body completes the action, all in one symbol (Guest 1984, 84).

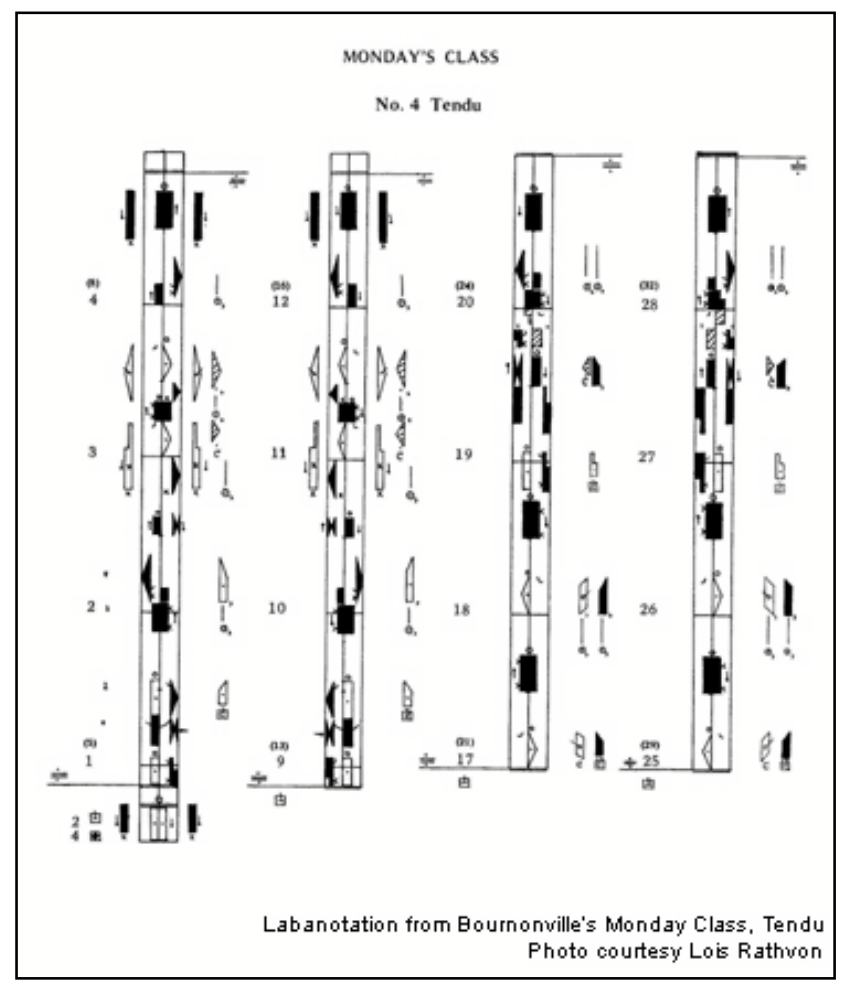

Fig 8: A ballet exercise notated in Labanotation.

The other widely used system, developed by Joan and Rudolf Benesh is made up of 32,000 symbols (Herbison -Evans 1988,46 ). In this system, the staff is the same as that of music, read horizontally and consisting of five lines, broken up by bar lines to determine timing. These five lines represent the different parts of the body: the top line is the dancer's head, the second the shoulder, the third the waist, the fourth the knees and the final the feet (Guest 1984, 99). Benesh then created symbols to represent the various movements, the direction of travel and other important instructions. 


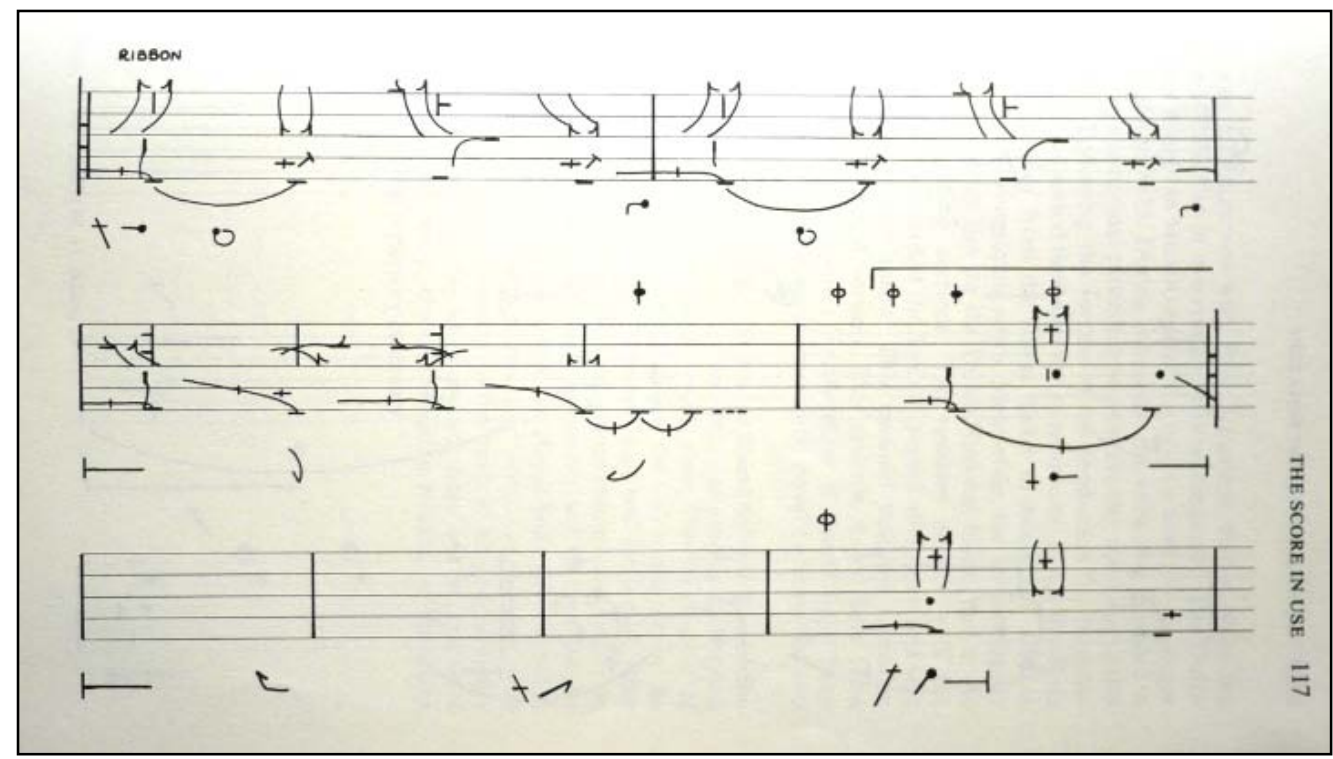

Fig 9: An example of choreography written in the Benesh notation system.

It is interesting to note that interdisciplinary interests, that is to say interests that extend beyond dance itself, seem to be a common characteristic of creators of dance notation systems. Arthur Saint-Leon, best known for choreographing Coppélia (1870), created a system closely related to music notation, as he was also a musician. Laban had been a student of architecture before he turned to dance notation; Noa Eshkol (of the Eshkol-Wachman Movement Notation System) was interested in mathematics and science; and Benesh was both an artist and an accountant (Guest 1984, 69, 86, 98). While these interests all seem quite different, each contributed to the respective authors' ideas of dance notation. Perhaps this is a reason why these systems are not accessible to all dancers: knowledge of dance alone is not enough to fully grasp them.

Marko Franko points out that today dance notation largely exists in the form of "personalised note-taking" (Franko 2011, 331). Even Martha Graham, who created her own system of notation, said that she wrote down abbreviated notes for her own personal use rather than using the system (Tembeck 1981/82, 74). Domenico's system was essentially a form of note-taking. Rather than using symbols like the later systems, he notated his dances by writing the name of the steps in the order they occurred within a particular choreography, just as Martha Graham would do five hundred years later. Why is it then, when about eighty five other systems have 
been created, that most dancers, teachers and choreographers still practise the same method of dance transcription that Domenico devised and used five and a half centuries ago? It seems that this basic, traditional approach is more accessible to both writers and readers of dance than a symbol-based system. In the next chapters I will be examining how Domenico notates his dances, why he writes them as he does, and how effective his system is. By doing so I will attempt to recreate some of his choreography and discover to what degree his writing has been able to preserve dance in time, thus proving his writing system as arguably the best able to record dance, despite its limitations. 


\section{Chapter Two: Domenico da Piacenza and the role of dance in fifteenth-century Italy}

\subsection{Historical context}

To understand why Domenico adopts his particular method of writing dance, it is important to understand first the context in which he writes, as well as ask ourselves why writing dance becomes a relevant preoccupation of the culture and society of the time. Up until the fifteenth century, nobody in the Western world had seen a need to notate dance, even though dance was a popular courtly activity for centuries prior to the Renaissance. What changed in society and inspired an Italian man to set out his beliefs and knowledge concerning dance technique in a manual, alongside written instructions for twenty-three of his choreographies? Who was this man, and what was his role within that society?

Furthermore, it is essential to determine who performed Domenico's choreographies, under what circumstances, and for what purpose or occasion. How popular was dance as an activity in fifteenth-century Italy? What kind of readership was Domenico writing for when he published his manual on dance? Why did he decide to write about dance in the form of a manual?

In Chapter One I gave a broad overview of the world of dance scholarship and notation, and established why it was important to preserve choreography in written form. Now I will focus directly on Domenico da Piacenza, the first person in the history of Western dance to recognise this important need. In this chapter in particular I investigate his life and his social surroundings in fifteenth-century Italy in order to discover what inspired him to notate his choreographies and discuss dance technique in his manual De arte saltandi et choreas ducendi.

\subsection{Domenico}

Domenico da Piacenza, also known as Domenico da Ferrara, Domenichino, or Domenegino, appears to have been born in Piacenza, c.1400, and to have died in 
Ferrara, c.1476. Acknowledged by his students and contemporaries as "re dell'arte" and "saltatorum princeps" (prince of the dancers), Domenico was an extraordinary dance master and choreographer (Brainard 2004c, 427). He created a new style of dance which was popular largely in northern and central courts in fifteenth-century Italy (Wilson 2006, 1).

Having made a name for himself in the first half of the fifteenth century, Domenico's teaching attracted dancers from all over Italy. Guglielmo Ebreo, one of Domenico's most prolific students, specifically came to Milan to learn from the best. In the treatise that Guglielmo went on to write in 1463 , he refers to himself as the: “Divotissimo dixipolo \& fervente Immitatore del dignissimo Cavalero Messer Domeneco de ferrara nell'arte Predicta del dançare doctissimo \& singulare quanto dala sua famosa \& prestan(te)" (Smith 1995, Vol. I, 127).

The "da Piacenza" attached to his name by Antonio Cornazano (another of Domenico's admiring students who in 1455 wrote his own manual) and other sources suggest that Domenico was originally from Piacenza, and probably spent his youth there. Much of his work, however, appears to have been carried out in other northern cities, such as Milan, Modena, Forlì, Faenza and Ferrara (Brainard 2004c, 427). In Ferrara Domenico did a large amount of his work as dance master. There the d'Este family appointed him "maestro di buone maniere ed esperto danzatore" (Pontremoli 2009, 264). In 1439 Domenico is listed in the Este court registers of the mandati (ambassadors/diplomats), but it seems likely that he introduced himself to the family in 1435 , at the marriage of Leonello (his future patron) to Margherita Gonzaga (Brainard 2004c, 427), as it is for this occasion that he may have created the dance Lioncello Novo, which I will analyse in detail later.

Domenico's name appears again in the mandati registers for the Este court in later years. According to the director of the Archivio di Stato di Modena who retrieved relevant documents in 1959, Domenico was active in Ferrara and was paid for his services in 1439, 1441, 1445, and 1450. The same letter also states that his wife was of the Trotto family (Smith 1995, Vol. I, 5). Her name was Giovanna and her family 
were courtiers and ambassadors for the d'Este family (Brainard 2004c, 427). This marriage shows Domenico must have belonged to the upper classes, as marriages of the time were agreed upon according to status, to further a family's social standing by making an allegiance with another high-standing family (Nevile 2004, 14).

In April of 1455, records show that Domenico was in Milan at the request of Francesco Sforza to choreograph dances for the wedding of his son Tristano Sforza to Beatrice d'Este (Brainard 2004c, 427). A letter from Piacenza, from the professor of rhetoric at Milan, Gabriele Paveri-Fontana, to Antonio Guidoboni, a Milanese ducal orator at Venice, notes:

\footnotetext{
Postea Galiacius Sphortia cum Hyppolita sorore pulcherrima primo, dein reliqui pro nuptiali more ad numerum saltarunt. Blanca Maria cum Dominico Placentino, Barbara cum Gulielmo Monferratino, Beatrix cum Alexandro Sphortia patruo et Hippolyta cum Galiacio fratre: qua quid pulchrius, quid jucundius, quid spectaculo dignius usquam videri potuit.
}

[Galeazzo Sforza was seated with Ippolita, the eldest daughter, then for the wedding festivities many danced...Bianca Maria with Domenico da Piacenza, Barbara with Guglielmo of Monferrat, Beatrice with Alessandro Sforza, and Ippolita with Galeazzo, her brother. Here there was joy, and it was majestic spectacle to see] (Smith 1995, Vol. I,6).

Later in 1455, probably in October, Guglielmo states that he, along with Domenico, choreographed dances for the engagement of Ippolita Sforza to Alfonso d'Aragona (Smith 1995, Vol. I, 6). Guglielmo does not mention the date, but other records pertaining to Ippolita and Alfonso and their engagement give us this date. ${ }^{3}$ It is unknown if Domenico was resident dance master for the Sforza family at this time, or if he was called in specifically for this event (Brainard 2004c, 427). Domenico joined forces with Guglielmo on another occasion, this time in Forli for the wedding celebrations of Pino de Ordelaffi and Barbara Manfredi in May 1462 (Smith 1995,

\footnotetext{
${ }^{3}$ For further discussion, see Smith, Fifteenth-Century Dance and Music Vol. I: Treatises and Music, p.6.
} 
Vol. I, 6). By now Ferrara seems to be where Domenico is permanently based (Brainard 2004c, 427).

The name Domengo da Piacenza can be found in the salariati (employees) of the Este court as being paid a monthly salary of twenty lire marchesani - a fairly substantial earning (Brainard 2004c, 427). His name is listed until 31 December 1472 and appears sporadically again throughout 1475 (Brainard 2004c, 427).

TABLE 1

Monthly salaries of musicians and others under Borso d'Este Court of Ferrara 1456

$\begin{array}{lr}\text { Pietrobono (celebrated lutenist) }^{\prime} & 8 \mathrm{LM}^{2} \\ \text { shawm player (German) } & 8 \mathrm{LM}^{2} \\ \text { shawm player (German: Corrado de Alemagna) } & 30 \mathrm{LM}^{3} \\ \text { trumpeters } & 10 \mathrm{LM} \\ \text { harpist } & 4 \mathrm{LM} \\ \text { Niccolò Todescho (German singer and lutenist) } & 24 \mathrm{LM} \\ \text { Domenico da Piacenza } & 20 \mathrm{LM} \\ \text { cook } & 6 \mathrm{LM} \\ \text { Guarino da Verona (famous humanist; last years) } & 25 \mathrm{LM} \\ \text { physician } & 40 \mathrm{LM} \\ \text { notary } & 10 \mathrm{LM} \\ \text { chief financial officer } & 20 \mathrm{LM}\end{array}$

Other monthly salaries and comparative expenditures

Antonio Cornazano (1455; court of Milan) 12 lire (plus clothing allowance) ${ }^{4}$

Antonio Cornazano (1476; court of Ferrara) (about) $50 \mathrm{LM}^{5}$ Cornazano (1465) receives 60 ducats from Borso

d'Este for 2 beautiful volumes honouring Borso ${ }^{6}$ (about) $192 \mathrm{LM}^{7}$

Francesco Filelfo, leading humanist at the court of Milan (1466)

70 lire $^{4}$

Wedding festivities in Rimini ( 1475 - 8 days) for Roberto Malatesta and Elizabetta Montefeltro ${ }^{8} \quad 35,000$ ducats $(112,000 \mathrm{LM})^{7}$

' In 1441, when Pietrobono was 23, Borso presented him with 20 gold ducats (about 64 LM), the same amount given to Dufay on two occasions. In 1476, Duke Ercole paid Pietrobono $18 \mathrm{LM}$ per month. Pietrobono is mentioned by Cornazano in his Libro dell' Arte del Danzare, fol. 5 r.

${ }^{2}$ LM indicates 'lire Modenese'.

${ }^{3}$ In 1476 Corrado was paid 26 LM.

4 Pontremoli and La Rocca, 33.

${ }^{5}$ Gundesheimer, Ferrara, 290-95.

${ }^{6}$ Pontremoli and La Rocca, 35.

'According to Lockwood (176), 10 ducats = 32 LM, depending on the year, the particular court, etc.

${ }^{8}$ D. Bornstein, 'The Wedding Feast of Roberto de' Malatesta and Isabetta da Montefeltro: Etiquette and Power', paper delivered at the 19th Congress of Medieval Studies, 1984, Kalamazoo, MI, based on documents from the Civic Library, Rimini.

Fig 10. Monthly salaries of musicians and others at the Borso d'Este Court of Ferrara, 1456. 
Domenico was knighted for his contribution to dance. Knighthood was the highest title one could gain when not born noble (Pontremoli 2009, 265). The exact date is unknown, but he must have been knighted before 1463, as Guglielmo acknowledges Domenico as "dignissimo cauagliere" in his dance manual, published in this year. Cornazano furthers the reference by adding the word "aurato" to "cavagliere", making it apparent that Domenico was a knight of the Militia Aurata (Smith 1995, Vol. I, 5). Cornazano's manual is supposedly dated 1455, therefore Domenico must have been inducted to the Militia Aurata before this year. A. William Smith suggests that he was knighted in 1452, as this is when the Emperor Frederick III visited Italy. Frederick presented many knighthoods that year and did not return again to Italy until 1469 (Smith 1995, Vol. I, 5). Although there is not further documentation about this, all seems to indicate the high status that Domenico had reached within the court.

Lack of documentation pertaining to Domenico makes it difficult to assert anything further about Domenico's personal life (Pontremoli and La Rocca 1987, 23). However, of his contribution to the dance world we can be sure:

\footnotetext{
A Domenico si deve il pionieristico tentativo di far accettare al potere costituito e alla collettività la danza come arte liberale, di pari dignità rispetto alla musica e alla pittura, che pure, nella stessa epoca, vengono sottoposte ad un processo di revisione teorica (Pontremoli 2009, 265).
}

As Pontremoli argues, Domenico was the first person to raise the status of dance to the level of the other arts. This makes him without doubt the founding figure in European dance scholarship.

\subsection{The dance master}

Although a pioneer in other aspects of the dance world, Domenico was not the first person to teach dance. Dance had already been practised by the nobility for important occasions and for social enjoyment in the thirteenth and fourteenth 
centuries (Nevile 2004, 8). Records show that Rabbi Haçen ben Salomo of Saint Bartholomew's Church in Zaragoza, Spain, taught a dance to his congregation in 1313 (Brainard 2004b, 336). However, he is the only named dance instructor before Domenico and did not write anything down like the Renaissance dance masters did. It was in fifteenth century Italy where this interest in the codification of dance first arose (Crisp 1981, 119). There was not only an interest in developing a physical set of skills, but a more intellectual understanding of dance: "Now, for the first time, the dancing teachers aimed at precision, striving for elegance of movement and the creation of a well-defined vocabulary of steps" (Sorrell 1981, 42-43). It is also in this era that maestri di ballo begin to be considered professionals of dance (Pontremoli and La Rocca 1987, 17).

Now, instead of just teaching basic movement, maestri di ballo were choreographing particular dances for their patrons and other members of the court. Unlike folk dance, which involved any number of people dancing known steps in any order they liked, in the Renaissance courts, dances were choreographed for a specific number of people to perform in a pre-determined order with a floorpattern established by the dance master. It is at this point in history, with Domenico da Piacenza, that dance masters can begin to claim authorship of dances, as they become not only teachers, but choreographers too.

The role of dance master as choreographer may also explain the additional development of dance master as dance writer. Now that there were particular choreographies, not just a few steps that could be performed in any sequence, there was more demand to write them down in a form that would serve both as a learning and practising tool. This is what separated the popular dance from the court dance: folk dances were not set choreographies and were not written down, thus writing down a dance was a way a dance master could claim authorship of it. In cases where the dance was not their own creation, for example when Cornazano or Guglielmo incorporated a dance of Domenico's in their manuals, they were very careful to give appropriate acknowledgement to the original choreographer. 
Interestingly, Domenico does not mention where or from whom he learned to dance (Nevile 2004, 131). His two disciples, Guglielmo Ebreo (or Giovanni Ambrosio as he was known after his conversion to Catholicism) and Antonio Cornazano, proudly reference Domenico as their teacher in the treatises they went on to write. They both use Domenico's name to give a sense of authority to their own work. For example, Cornazano writes: "In questo Misser Domenichino vostro bon servitore e mio maestro ha havuto evidentissimo giudicio dicendo che I dançare specialmente di misura larga vole essere simile ad ombra phantasmatica" (Smith 1995, Vol. I, 88).

Dancing was not the only practice these maestri di ballo were expected to teach. Other skills could include music, athletics, fencing, riding and other physical activities, as well as providing their pupils with an intellectual and artistic education (Brainard 2004b, 336). An education in dance was also valued as it taught one the social behaviour and deportment required of the aristocracy (Nevile 2004, 2). Although Guglielmo tells of choreographing dances for popular festivals too, Cornazano and Domenico seem to have taught the elite only (Brainard 2004b, 336).

The status of the maestri di ballo is often debated. Sparti suggests it was not a prestigious role (Sparti 1996b) but others state it was. Clement Crisp and Mary Clarke write that dance masters were "sometimes the intimates and trusted confidants of royalty" (Crisp 1981, 119); Guest calls them "highly esteemed" (Guest $1984,43)$, and Ingrid Brainard talks of how sought after the maestri di ballo were (Brainard 2004b, 336). The most powerful, cultured families (Este, Gonzaga, Sforza, Medici, Bentivoglio, Aragon) vied for the best dance masters. The maestro di ballo, would then have to reflect the nature of this family's court in his work (Lockwood $1084,72)$. The fact that dance masters were associated with the nobility and that there are records of them dancing in public with members of the ruling class (Domenico danced with Bianca Maria Sforza, Guglielmo danced with Isabella d'Este, and Cornazano danced with Ippolita Sforza) suggests that they enjoyed a relatively high status themselves: it would not be acceptable for a noble lady to dance with someone socially too inferior to them (Nevile 2004, 15-16). 
Domenico, Guglielmo and Cornazano appear to be sought-after dance masters, with nobility approaching them for work, but a letter from dance master Filippus Bussus to Lorenzo de' Medici before the latter's marriage to Clarice Orsini in June 1469 suggests some dance masters had to find work for themselves:

\footnotetext{
And if you would like to learn two or three of these balli and a few bassadanze from me, I would come eight or ten days before the festa to teach them to you with my humble diligence and ability; and in that way it will also be possible to teach your brother Giuliano and your sisters so that you will be able to acquire honour and fame in this festa of yours by showing that not everyone has them [i.e., the dances], since they are so little known and rare (Nevile 2004, 29).
}

There may well have been other less-famed dance masters than Domenico and his disciples. Less is known about them because they were not as intellectually skilled and aware of their role: not all dance masters wrote treatises. There is evidence to suggest middle-class members of society were taught dance too. They would not have been taught new dances, as the nobility often were, but instead would learn the dances the elite had been practising five to ten years earlier (Nevile 2004, 6). Cornazano mentions in his treatise that in his time some of Domenico's dances were already danced by the bourgeoisie (Sparti 1986, 257). Moreover, some records name teachers who may have taught the middle classes: Deodato and Mariotto Marchetto worked in Perugia (Nevile 2004, 25) and Guglielmo's brother Giuseppe taught in Florence (Celi 2004b, 542). The dedication of some of these dance teachers is demonstrated by three masters who drew up a contract in October of 1493 to teach dance and music for ten years in Siena (Nevile 2004, 25). These examples of teachers outside the Lombardy region indicate the growing status of the dance master. Although I will not examine them in this thesis due to the limits of my scope, other styles of dance existed alongside the ballare lombardo tradition. Throughout Italy, maestri di ballo were being employed to teach the upper classes how to dance elegantly and gracefully, and each region did so with their own flair. It was the dance masters from Lombardy, however, who recognised the Renaissance desire to codify the arts and who wrote down their ideas about technique, as well as their choreographies, in manuals. 


\subsection{An activity for the elite}

There are very few references to the dances common citizens practised in fifteenthcentury Italy. Florentine records mention events such as May Day festivals that involved young people dancing in the piazze and streets with "boisterous songs and lusty movements" (Sorrell 1981, 44). Sparti suggests these "lusty" dances were "improvisatory saltarello and rustic piva" (Sparti 1996b, 52). Although the dancing the upper classes did was presumably derived from popular dances and then polished by the dance masters, Domenico and his disciples recognised it in its court form only (Celi 2004b, 542). Dance, as they saw it, was "una disciplina elitaria" (Pontremoli 2009, 32). As society was separated along social lines, so dance was divided into peasant folk dance and court dance (Brinson 1963, 13).

The dance masters made it clear in their treatises that they intended their dances to be performed by the elite only, as exemplified by Guglielmo Ebreo:

\footnotetext{
Optimamente Exercitare la quale ali namorati \& Generosi cuori \& ali Animi gintili per Celeste inclinacione piutosto che per Accidentale disposicione \& amicissima Et conforme Ma aliena in tucto \& Mortale innimica di viciosi \& Mechanici plebei li quali Le piu volte Con Animo corrupto \& con la scelerata Mente La fanno di arte liberale \& Virtuosa sciencia adultera \& servile (Smith 1995, Vol. I, 127-28).
}

Guglielmo's lesson is expanded when he writes that it is not only the mind and spirit that have to be good, but the body as well. To dance well is easier for those who have a body that is "libera sana \& expedita Sença alchun mancamento di soy membri Ma giovene conformoso Destro ligiero \& di gracia ben dotato" (Smith 1995, Vol. I, 133). At the same time, practising dance was the only activity the elite could do that would develop three main pre-requisites for being a courtier: "agilità corporea, belle maniere ed elevazione dello spirito" (Pontremoli and La Rocca 1987, 138).

Thus, dance was a fashionable activity as it was one of the means of distinguishing the elite from the commoners: good dancing proved high social status (Brainard $2004 b, 336)$. It was not only part of everyday life, but a social duty too. Members of 
the court were expected to dance on ceremonious and festive occasions (Pontremoli 2009, 34). Dancing, therefore, was a part of a prince's or aristocrat's education and the best courtiers had "una complementarità dell'educazione della mente e del corpo" (Pontremoli 2009, 32). The skills a courtier was taught by their dance master were not just applied to dancing, but were also used in everyday court life. The deportment and behaviour used on the dance floor were expected in court by all its members as it was an indication of their refined elite upbringing (Nevile 2004, 2).

Dance was also a symbol of power and wealth (Sparti 1996b, 43). Italy was not unified in the fifteenth century; instead every region had its own political system. Some states, such as Ferrara, Mantua, Milan and Naples were run by a prince or duke; Venice and Florence were republics; Rome was run by the papal court (Nevile $2004,5)$. One family usually sat at the top of the hierarchy in each state, for whom the dance masters worked and wrote and for whom magnificence and spectacle were a common way to display their power (Nevile 2004, 5). In this sense, dancing was used as political propaganda to assert the status of the ruling family in relation both to those who were ruled by them and competing aristocratic families (Guest $1984,43)$. As dancing was "ostentatious by nature", it was the perfect way to impress others (Anderson 1974, 12).

Fifteenth-century Italy saw dance become more theatrical as a result of its use as a symbol of power. Some intermezzi (small performances danced in between meals at banquets) grew quite lavish, and turned into magnificent spettacoli (Pontremoli $2009,34)$. Court dance was not only something all nobles had to do socially, but it became a spectacle too (Pontremoli 2009, 34). Dignitaries and rulers from other regions would be expected to perform with skill and elegance when visiting other regions. For example, on 17 October 1476 a ball was held in Ferrara in honour of Beatrice d'Aragona, before she married the king of Hungary, Matthias Corvinus. At this event, a group of Hungarian men danced for the entertainment of the court (Nevile 2004, 23). 
The intertwining of dance and politics can already be seen at play in fourteenthcentury Italy, as illustrated in Ambrogio Lorenzetti's painting Allegoria degli Effetti del buon Governo in Città ("The Allegory of Good government and its effects on town and country" 1338-39). The central figures are grouped as people dancing. The other part to this Sienese fresco shows the Allegoria degli Effetti del cattivo Governo in Città ("Allegory of bad government"): no dancing appears in it.

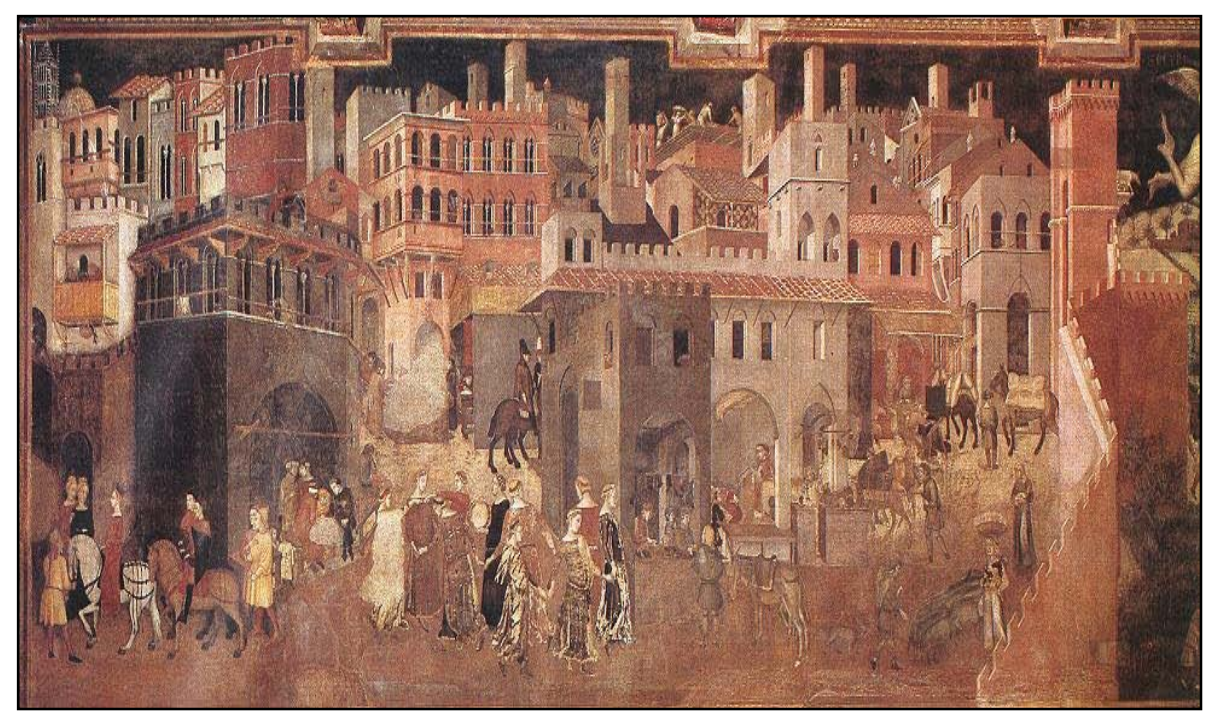

Fig 11: Allegoria degli Effetti del Buon Governo in Città, 1338-39.

Another striking example of political power and dance being directly linked, although not from Italy, is the allocation of voting power to only "those families who used to dance in the Rathaus in the olden days, and who still dance there" in Nuremberg in 1521 (Nevile 2004, 46). This suggests that political power and dance ability were seen by the upper class as strictly linked throughout several centuries that include the Renaissance.

One of the most important courts for dance in fifteenth-century Italy was Leonello d'Este's court in Ferrara. Domenico, Guglielmo and Cornazano are all recorded as having worked there at some point (Lockwood 1984, 70). Domenico was an official member of the court, employed as maestro di ballo, working from at least the 1430s (Lockwood 1984, 70). All three dance masters were instructed to compose new dances for the court as the elite always wanted the latest in fashion. The dances Domenico and his followers taught could be performed in both public and 
private settings. Privately, ladies are known to have danced for their own pleasure in their chambers (Sutton 2004, 352; Sparti 1996b, 47), and exclusive performances were held for a small, princely audience (Sparti 1996a, 268). Young Ermes, the son of Galeazzo Maria Sforza, danced on such an occasion when he was not yet five years old (Nevile 2004, 23). Children could also dance in public, as Isabella d'Este did from the age of six and Ippolita Sforza did from age ten (Nevile 2004, 23). Publicly, balli were performed indoors in the courts, or sometimes outdoors, in costumed moresche $e^{4}$ performances (Sutton 2004, 352).

People attending these public balls would be seated according to their social rank (Nevile 2004, 51). Pontremoli describes it as "lo specchio della loro posizione all'interno della scala sociale" (Pontremoli 2009, 35). The ladies were seated on one side of the room, and the men seated on the other, as illustrated in the description of the hall for the festivities in honour of the wedding of Elizabetta Gonzaga and Guidobaldo da Montefeltro:

\begin{abstract}
By the right-hand side of the entrance is the dresser covered with a large amount of silver plate and vessels. By the other side is the dais, decorated with crimson velvet and pieces of cloth of gold. Along one side of the hall, from the top of the pillars of the vault as far as the benches, pieces of crimson and green velvet are stretched onto square frames with columns of painted wood. And the ladies stay along this side of the hall. Along the other side are scaffolds with steps, where the men remain to watch, [and] from the scaffolds to the top of the pillars are also pieces of green and sky-blue velvet stretched around the columns as is done on the other side. And the body of the hall is left free for the dancing. At the dresser end of the hall there is a pit for the musicians, and also the ladies who are not part of the dancing (Nevile 2004, 35).
\end{abstract}

Celebrations such as weddings were popular events to showcase dancing. Dance masters like Domenico and Guglielmo could be sent by their employer to another court to teach a prince a special dance for a wedding or other such celebration (Sparti 1996b, 50). Sometimes they could be approached by others too, to help with

\footnotetext{
${ }^{4}$ The moresca was a theatrical type of dance, portraying mythological or allegorical stories, where the performers often wore masks and extravagant costumes (Nevile 8).
} 
the preparation of a wedding. For example, Isabella d'Este wrote to ask her brother Cardinal Ippolito d'Este if she could borrow Ricciardetto, his dancer, to come and practise with her before the wedding of their brother Alfonso to Lucrezia Borgia in 1505. Lucrezia was known for her skilful dancing and it seems that Isabella did not wish to look second best (Nevile 2004, 30).

The records published in Vicenza of the wedding of Costanzo Sforza and Camilla d'Aragona in 1475 help us to understand the role of dance in such a celebration. The celebrations took three days, with the middle day seemingly dedicated to dancing, both social and theatrical in form (Nevile 2004, 36). Many different types of dancing were involved, including single-sex, couple dancing, processional, social and moresche (Nevile 2004, 38). Dancing was even present at the banquet: 120 men carried food in dancing a piva "quasi come uno bissone[...]o in forma de questi littera S" (Nevile 2004, 37).

Festivals such as these became a means for some gifted members of ruling families to display their skills. Cornazano writes of how beautifully Beatrice dances: "Chi vole vedere el paradiso in terra veggia Madonna Beatrice in su una festa" (Smith 1995, Vol. I, 86). Lorenzo de' Medici and Ippolita Sforza were both recognised as talented dancers too. In fact, they both were so brilliant they composed dances also, and were praised for doing so (Nevile 2004, 19). Guglielmo includes in his manual Lauro, a bassadanza created by Lorenzo de Medici himself, which indicates he must have been respected by professionals as a good choreographer (Pontremoli and La Rocca 1987, 69). Records from Guglielmo also show that Ippolita choreographed dances: in a letter Guglielmo (by then known as Giovanni Ambrosio) wrote to Bianca Maria Sforza in 1465, he states that Ippolita has choreographed two new balli. He writes that she took the tunes from French songs, and sang them as she danced her own choreography (Gombosi 1941, 294).

\subsection{Gender roles}

Renaissance Italy was dominated by men. Aristocratic women were not allowed to participate in a number of activities that men were, as the rules of society deemed 
it unseemly. Dance was one social activity in which they were allowed to take part, an activity in which they seem to have had a degree of control. Both men and women at court were encouraged to undertake dance training as a means of keeping fit, but as this was one of the very few types of physical exercise they were allowed, women often spent more time learning and practising and therefore excelled at it (Pontremoli and La Rocca 1987, 137). Because they were left out of numerous other activities, dancing was a way for ladies to pass the time pleasantly (Pontremoli and La Rocca 1987, 154). This was sometimes done in private as a leisure activity and sometimes done in public at festivals and celebrations. Although most of the choreographies from the manuals involve both males and females, ladies seemed to have danced as often with their ladies-in-waiting or with each other (Sparti 1996b, 47). Bianca Maria Sforza described her daily activities whilst staying in Innsbruck with the archduke Sigismondo and archduchess Caterina in a letter to Ludovico Sforza:

\footnotetext{
E quello giorno e così tutti li altri seguenti, quaxi fine a le sey hore de nocte, havemo consumato in gaudij et in piacere con lo Illustrissimo Signore Arciducha parte in ballare e parte in videre zugare la prefata Domina Arciducesa con alchuni altri signori et cavalieri de li suoi et de li nostri: e queste feste qualchi volta sono facte in publico et qualchi volta privatamente ne la camera nostra (Pontremoli and La Rocca 154).
}

More references pertaining to dance in surviving letters, diaries and records from fifteenth-century Italy are about women than about men. For example, a 1459 record from Florence states that "circa centocinquanta donne tute azoiate et ornatissimamente vestite" were present at the dance event in Mercato Novo to honour Galeazzo Maria Sforza (Pontremoli and La Rocca 1987, 176). Pontremoli and La Rocca suggest that this could be a remnant of the stil novo tradition popular in Medieval Italy, where men wrote poetry idealising the female figure. The idea that the female figure was "come all'incarnazione di tutto ciò che è raffinato, bello e degno di riverenza" was still a part of fifteenth-century courtly culture (Pontremoli and La Rocca 1987, 176-77). 
Guglielmo dedicates an entire chapter in his manual De pratica seu arte tripudii (1463) to rules for female dancers. He writes that while it is important for a woman to understand all the rules regarding dancing that he discusses in his treatise, she must do so "con piu modeça Assai \& piu honestate che e al omo" (Smith 1995, Vol.1, 141). Guglielmo talks of how a woman's movements should be refined and humble:

\footnotetext{
Non sia con gli ochi suoy alteria o vaga-Bonda Mirando hor qua hor la Come Molto fanno ma honestamente el piu Del tempo reguardi la terra, non portando Pero come Alcune fanno el capo In Seno A basso ma diricto suso \& ala per-Sona respondente come quasi per se Midesimi la natura insegnia (Smith 1995, Vol.1, 141).
}

Baldassare Castiglione, whose renowned manual of court politics and social manners II libro del Cortegiano was published in 1528, agrees that a lady must dance "con una certa timidità, che mostri quella nobile vergogna che é contraria della impudenza" (Castiglione 1960, 257). He also states that a lady must not "usar movimenti troppo gagliardi e sforzati" when dancing (Castiglione 1960, 256). Dance master Antonio Cornazano also makes this point in his manual when he writes: "non e bello alla donna altro che gli suoi passi naturali" (Smith 1995, Vol.1, 87).

Thus it seems that although female dancers were the celebrated gender at festivals of dance, women were not allowed to do as much as men. Men had additional, more complex steps that they were allowed to perform in public that women were not, and therefore appeared more virtuosic than women if their technique was correct. So it seems that although women enjoyed a degree of freedom and control over the world of dance, their leadership in it was still limited.

\subsection{Philosophy and the aesthetics of dance}

Alongside its ability to demonstrate power and prestige, dance was a means "for the harmonious development of the psychological and physical aspects of the human personality" (Celi 2004b, 542). The philosophy of the Renaissance was that of the humanists, who believed that of everything in the universe, mankind was the most important (Celi 2004b, 542). The human body therefore became central in 
Renaissance culture: having been given the gift of such an extraordinary body, one must learn how to use it accordingly. Leon Battista Alberti wrote: "To you is given a body more graceful than other animals, to you power of apt and various movements, to you most sharp and delicate senses, to you wit, reason, memory like an immortal God" (Sorrell 1981, 46). Dance was thus an important outward demonstration of how beautiful and exceptional the human body could be.

A dance master had to be "custode dei segreti del mestiere ma nel contempo dotto teorico in grado di giustificare, con il discettare filosofico, la dignità e la leggittimità della propria arte" (Pontremoli 2009, 32). Domenico's treatise De arte saltandi et choreas ducendi thus reflects many of the humanists' beliefs, ranging from their theories of grace, beauty and imagination (Carter 2004, 22), to their use of classical references and languages to add a sense of authority to their work (Sparti 1993, 375). In fact, the humanist obsession with classical antiquity is part of the reason an abundance of treatises were being written at this time, some in Latin and some in the vernacular (Sparti 1993, 373). The humanists believed that to run a state successfully, one must be proficient in both spoken and written language (Nevile $2004,9)$. As well as the codification of the arts (Pontremoli 2009, 32), treatises were used to discuss subjects such as the family and education (Sparti 1993, 373).

Two of the humanists concerned with education ran well-known schools: Vittorino da Feltre had one in Mantua, and Guarino Guarini one in Ferrara. Both humanists mention dance in their treatises on education. Guarino states that dancing is an acceptable part of an education, and records of saltatores (dancers) in lists of specialist teachers at Vittorino's school suggest that dance was part of their curriculum too (Nevile 2004, 20). Vittorino does mention, however, that dance was only acceptable when it did not lead to "indolence or sensual excitement" (Sparti 1993, 384). Castiglione stresses this idea of moderation in I/ libro del Cortegiano: "rida, scherzi, motteggi, balli e danzi, nientedimeno con tal maniera, che sempre mostri esser ingenioso e discreto ed in ogni cosa che faccia o dica sia aggaziato" (Castiglione 1960, 51). Likewise, Giovanni Pico della Mirandola discusses how important imagination is to the Renaissance man - how it had its own "inventive 
function" and how it "would produce the artistic forms of movement created by the dance composer" (Carter 2004, 21). At the same time, however, he acknowledges the fact that imagination could not only benefit the good, but the evil too. Thus, he suggests that one should "direct the eye of the mind to God" (Carter 2004, 21).

Alongside imagination, beauty and grace were important qualities the humanists were concerned with. Naturally, these aesthetic issues were applicable to dance, and often dance was used as an example of such qualities. Marsilio Ficino writes of how "a dance might exemplify human striving for beauty", and Castiglione focuses heavily on sprezzatura, a concept of "studied nonchalance" (Carter 2004, 21). One must appear natural and a dance must therefore not appear difficult, even if it is: "Medesimamente nel danzare un passo solo, un sol movimento della persona grazioso e non sforzato, súbito manifesta il sapere de chi danza" (Castiglione 1960, 59). Castiglione says the courtier must abide by these three rules: appear natural, meet the rules of social decorum and reveal a fundamental beauty (Carter 2004, 21). Dancing was a way in which one could do all three.

To dance poorly was evidence that one was not truly noble. Bad dancers were mocked by the social elite, as Castiglione reminds his readers:

Qual di voi è che non rida quando il nostro messer Pierpaulo danza alla foggia sua, con que' saltetti e gambe striate in punta di piede, senza mover la testa, come se tutto fosse un legno, con tanta attenzione, che di certo pare che vada numerando i passi? (Castiglione 1960, 56).

Dance was considered an outward display of one's soul, which is why it was so important to dance well. Only a person who was in control of his body had the ability to rule a state, or even a noble household, the perfect illustration of which, according to Castiglione, was Lorenzo de' Medici (Smith 1995, Vol. I, xx).

It is important to understand the context of the humanist intellectual debate as the dance manuals written by Domenico and his disciples were influenced by it and contributed to shaping it in turn. The elite desired to understand dance 
intellectually as well as practically, so as to separate themselves from the common people (Nevile 2004, 2-3). The dance masters stressed the importance of recognising dance as an art and a science, an exercise that could be understood not only through the body, but through the mind too (Nevile 2004, 3). Leonardo da Vinci wrote that "[t]he love of anything is the fruit of our knowledge of it, and grows as our knowledge becomes more certain" (Sorrell 1981, 46). The dance masters appear to have recognised this, and so wrote manuals in order to share their knowledge about dance and hopefully inspire some passion in their pupils so that they would accept dance as a legitimate art or science.

\subsection{Music and dance}

Up until the fifteenth century, dance was largely taught by a music teacher, as an extension of a musical education (Brainard 2004b, 336). Music is an integral part of dance - the very foundation of dance comes from it, as Guglielmo acknowledges: “ermonia suave el dolce canto Che per l'audito passa drento al core Di gran dolceça nasce un vivo ardore Da cui el dançar puo vien che piace tanto" (Smith 1995, Vol. I, 122).

The music the dance masters used was usually self-composed and secular, as opposed to the large majority of sacred music of the time (Sparti 1986, 346). The dances themselves were social dances, for men and women. It seems that single sex dances and improvised dances were both part of the fifteenth-century dance culture, but they are not mentioned in the manuals, like the balli and bassadanze (Nevile 2004, 5).

The manuals do not expand on how to perform steps in great detail. Dance was such an everyday activity that the dance masters obviously did not feel that they needed to explain the steps, as everyone already knew how to perform them. They were quite simple steps by modern standards, suitable for both young and old people (Pontremoli and La Rocca 1987, 72). The steps were also apparently recognised outside of Italy, as indicated by the 1517 records of Johannes Cochlaeus, a German music teacher. The daughter of a leading citizen of Nuremberg sent 
Cochlaeus to Bologna to write down some dances. He notated eight dances in German, but kept most step names in Italian, or a somewhat Germanised Italian (Sparti 1996a , 257-58). This is also evidence that Domenico's steps were still being danced in the sixteenth century.

Domenico and the other dance masters include two types of dances in their treatises: the ballo and the bassadanza. The bassadanze were slow, processional dances, popular in central Europe from the fourteenth century to the second half of the sixteenth century. The earliest reference to a bassadanza is in 1430 , by Raimond de Cornet, a troubadour, written in the Cansos e bassas dansas (Brainard 2004a, 378). Domenico notates five bassadanze in De arte saltandi et choreas ducendi, though none of them are accompanied with music, nor are those of Guglielmo (Brainard 2004a, 380). Cornazano gives the tenor line for a small number of bassedanze in his manual (Smith 1995, Vol. I, 106). Cornazano also mentions that a bassadanza should be followed by a saltarello, a faster dance, although the other two do not (Brainard 2004a, 380). 


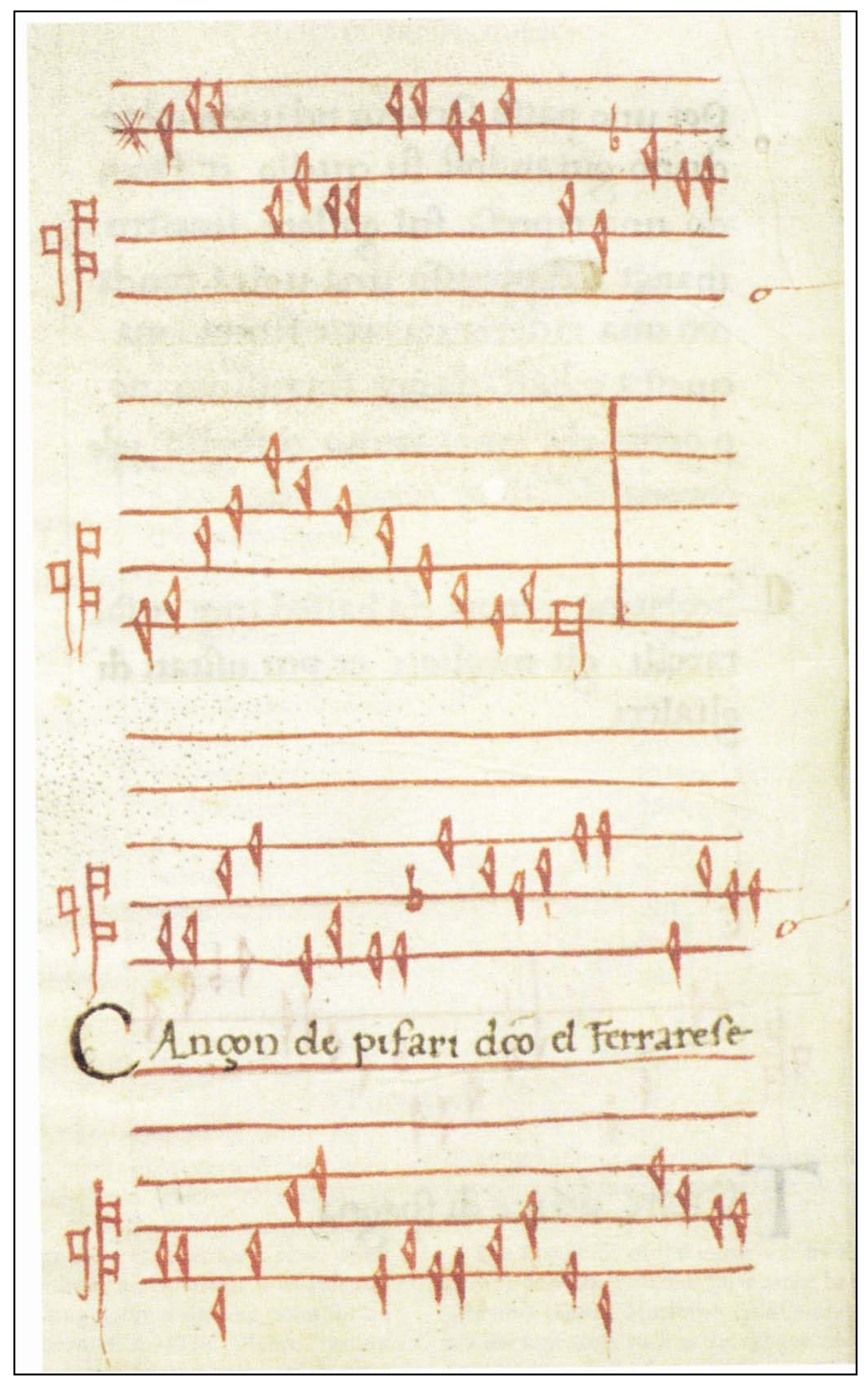

Fig 12: Part of the notated music for Re di Spagna and il Ferrarese. From Cornazano's Libro dell'arte del danzare, 1455.

The bassadanza is likely to have come to Italy from France or Burgandy, although it is the Italians that made it more detailed and complex (Brainard 2004a, 380). The ballo, however, was an Italian invention. Domenico and his followers created these for the elite. A ballo was more complicated than a bassadanza, largely due to its 
frequent changes of tempo (Crisp 1981, 94). It was often more theatrical too, with some balli having a dramatic or pantomimic element (Sparti 1986, 346).

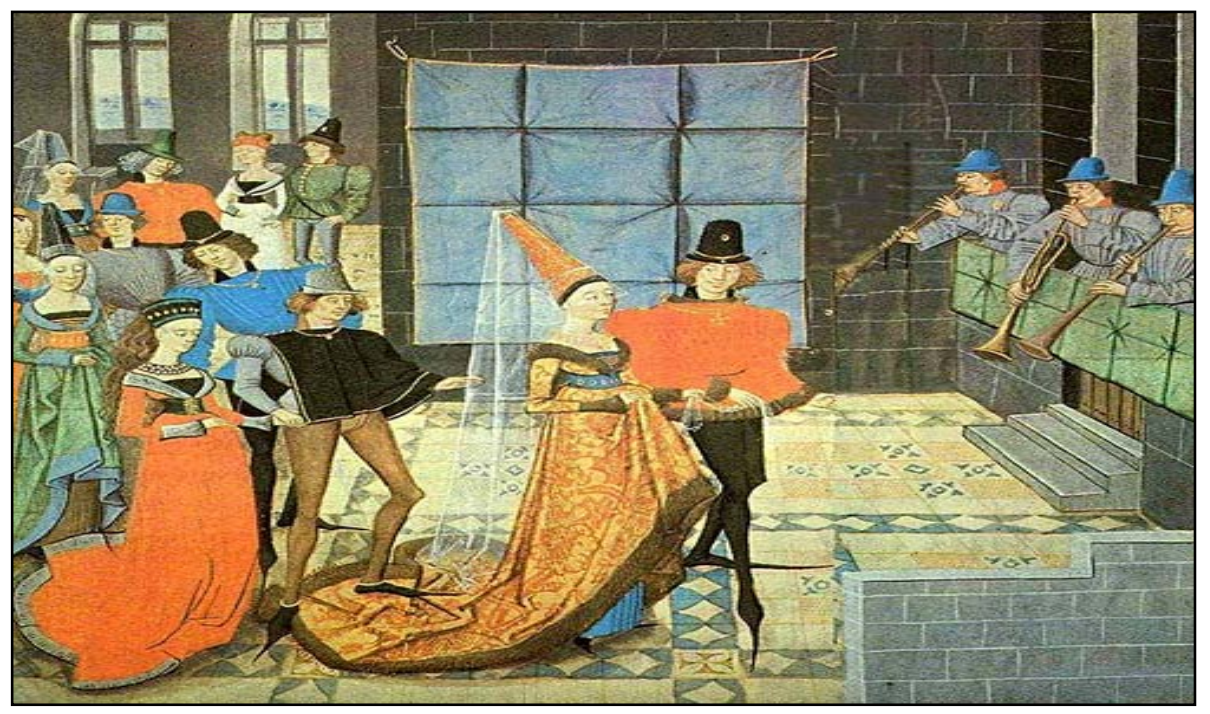

Figure 13: Bassadanza, fifteenth-century miniature.

Domenico "fashioned and perfected the ballo", which he obviously preferred over the bassadanza, given the 18:5 ratio in his treatise (Sparti 1986, 346). Domenico's balli were choreographed for a number of dancers, some for a couple only, and some for as many as twelve (Sparti 1986, 347). The fact that the number of people dancing at any given time was limited shows how court dance was very much performance-based: if only a few people are dancing at a time, many more must be watching (Pontremoli and La Rocca 1987, 187), emphasised by the fact that most of the balli open with a saltarello, designed for the dancers to make their way to the centre of the hall (Sparti 1986, 347).

The halls used were usually longer than they were wide ( 83 passi long and 21 passi wide in the case of the ballroom at the d'Este palace Belriguardo), thus most of the patterns are rectangular (Nevile 2004, 32). Interestingly, a lot of the iconography of dance from the fifteenth century shows dancers in a circle, although only three balli employ this shape in their choreography (Nevile 2004, 32). Groups of dancers in a 
circle were often used by Renaissance painters for narrative or symbolic purposes, not to correctly represent the dance practices of the time (Fermor 1987, 18-19).

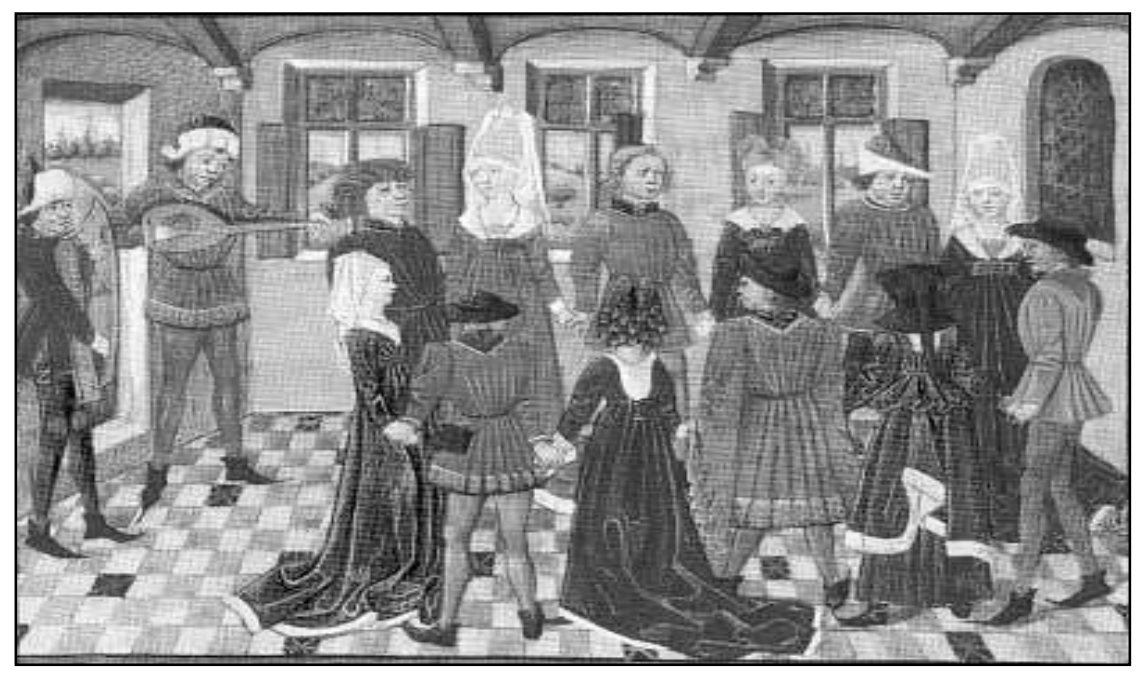

Fig 14: Court people performing a dance in a circle, $15^{\text {th }}$ century book illustration.

Julia Sutton describes the fifteenth-century balli as "playful" (Sutton 2004, 352).

The chasing, echoing, mirroring and circling patterns involved all support this idea. The choreography was fitted to the music by the dance masters, who often also composed the tunes (Sparti 1986, 346). The music was thus an essential part of a dance (Nevile 2004, 27). There are fifty balli in the fifteenth-century Italian repertory and each one has its own tune, matched by specifically chosen dance steps (Sutton 2004, 351).

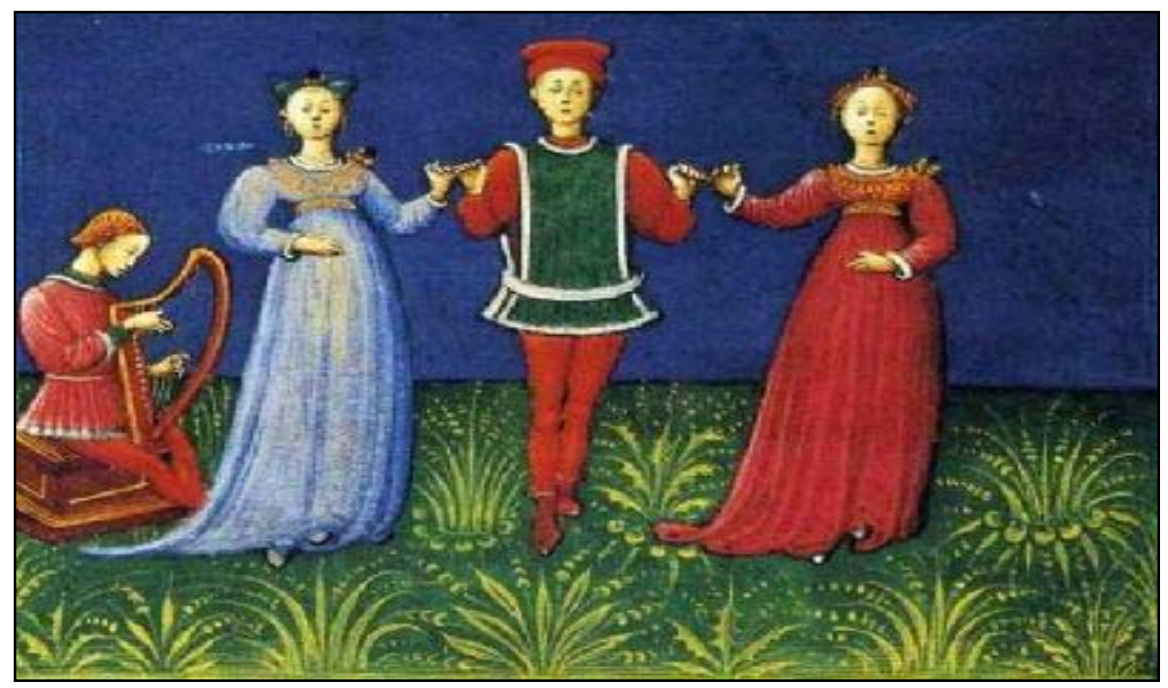

Fig 15: A painted miniature of a ballo for three from Guglielmo's De pratica seu arte tripudii, 1463. 
The fame of Domenico's balli is illustrated in the references to his dances in records outside of Northern Italy. There is no evidence of Domenico having ever worked in Florence, and yet his dance Rostiboli is mentioned in a description of the Pope's visit in 1459, as part of the entertainment (Sutton 2004, 352). Galeazzo Maria Sforza's visit to Florence, also in 1459, mentions Rostiboli, as well as Lioncello, Belriguardo, and other dances created by Domenico (Nevile 2004, 43). Rostiboli seems in fact to have been one of Domenico's most respected dances. It was deemed a great dance in 1530 by humanist Giangiorgio Trissino, likening its greatness to the painting of Leonardo da Vinci, or the poetry of Petrarch and Dante (Sutton 2004, 352).

\subsection{Professional dancers}

The manuals written by Domenico and his followers are not representative of all dancing done in fifteenth-century Italy. As previously mentioned, they deliberately exclude any dances performed by the lower classes, but they also do not contain choreographies designed for professional dancers, even though Domenico, Cornazano and Guglielmo are all known to have created some such dances. These types of dances were spettacoli designed for courtiers and dignitaries to watch rather than participate in. Such dances were known as moresche or mascare, popular in the second half of the fifteenth century and were performed by "professionisti, da balladori o dagli stessi maestri di danza" (Pontremoli and La Rocca 1987, 184), who were, for the most part, all men (Sparti 2001, 304). Occasionally, court members could partake in them too, but would have to do so wearing a mask (Castiglione 1960, 126): this was seen as "a temporary suspension of etiquette" in which "only the person took part and not the personality" (Gombosi 1941, 290).

These moresche were often performed as intermezzi at balls, or at weddings and other celebrations of important people. A huge sense of spectacle was involved: costumes were lavish, masks and headgears were ornate, scenery was often part of the show and special effects occurred too (in some cases even fire was used for spectacle!) (Sparti 1996b, 44). 
Moresche were the fifteenth-century equivalent of ballets today (Pontremoli and La Rocca 1987, 223). They portrayed a subject, theme or story through dance. Popular themes included rustici, la danza-battaglia (Sparti 2001, 302-03), I'amore and $i$ misteri della crescita e della vita (Pontremoli and La Rocca 1987, 223). More often than not these were told through classical allegories.

It is interesting to note that moresche are mentioned and described more frequently in primary sources such as diaries and journals than the court dances taught and choreographed by Domenico and his followers. This is probably due to the fact that moresche were one-off events and often involved great spectacle, whereas the courtly dances notated in Domenico's manual were a part of everyday life and thus were not notable enough for diarists to discuss in detail. These reasons are probably applicable to answering the question of why moresche were not notated in the manuals when we know the same dance masters choreographed them. As Domenico designed his manual as a practising tool for the elite, it was not necessary to include moresche notations as they were usually performed only once and were not part of everyday court ritual.

\subsection{Conclusion}

My final reflections on the notated court dances and the unwritten moresche highlight once again how important it is to notate dance. Although details are known concerning the themes, allegories, costumes and spectacle of moresche, very little is known about the steps and the choreographies. Many of the fifteenthcentury Italian moresche dances will remain forever lost, because nobody thought to write them down.

Fortunately for us, Domenico da Piacenza had the initiative to write at least some of his choreographies on paper. The Renaissance context of humanist writing inspired him to set out his ideas about dance as an art and a science, and clarify techniques and qualities required by the elite to dance well and thus uphold their social status. 
As a result of Domenico's efforts it is possible to attempt to reconstruct dances that were choreographed five and a half centuries ago.

This is what I have done. I have chosen three of Domenico's choreographies and investigated to what degree it is possible to recreate the dances using written text as my only base. In so doing, I have been able to recognise both the limits and the benefits of dance notation and discover precisely how effective Domenico's system of dance writing is.

In order to do so, though, it is important to understand the style of dance as practised in fifteenth-century Italy. Now that I have established who performed the dances and where, when and why they were danced, I must look at how they were performed. In the next chapter I examine the first, more theoretical and general part of Domenico's manual De arte saltandi et choreas ducendi. In doing this I aim to identify the main techniques involved in Domenico's style of dance so that when it comes to reconstructing his dances, I have an understanding of how the movements were intended. 


\section{Chapter Three: Domenico's De arte Saltandi et choreas}

\section{ducendi}

\subsection{The culture of writing manuals}

Before the Renaissance, dance seems to have been a practice taught orally and understood physically. It is only with Domenico and his manual De arte saltandi et choreas ducendi that dance becomes something to be understood intellectually as well as physically. As we saw in the previous chapter, the Renaissance was a time that saw a blossoming of treatises as a pedagogic instrument for a variety of topics. The manuals pertaining to dance were used by the elite as a way to understand technique, style, music, and the dances themselves.

The three dance masters Domenico, Cornazano and Guglielmo all wrote their treatises before the mid-1460s. Their work is linked to that of other intellectuals of the time on the subjects of music, art and architecture (Pontremoli 2009, 32). Whilst some of the manuals were written in Latin to heighten their intellectual nature, the manuals of the dance masters were written in the vernacular. This is most likely due to the fact that Domenico and other dance masters wanted their manuals to be accessible to all the elite, including women. If the dance masters had chosen to write in Latin instead, it would have limited their readership to welleducated men only. As reading was generally an activity for the elite alone, the fact that the dance manuals were written in the vernacular does not lessen their status as documents for the nobility: the lower classes would not be able to read them no matter which language they were written in. Thus, by writing his manual in the vernacular, Domenico ensured it was accessible to his target readership.

In this chapter I will examine the first part of Domenico's manual which deals with the aesthetics of fifteenth-century court dancing. This is an important preliminary exercise, as in Chapter Four I will attempt to reconstruct some of Domenico's choreographies and without some knowledge of style and technique this cannot be done accurately. In the first half of his manual, Domenico discusses techniques such 
as fantasmata, lists the steps in the fifteenth-century repertoire and explains the different misure of music and the appropriate steps to dance with each tempo. All of these aesthetic concepts must be understood before attempting to recreate the choreographies in the truest manner possible.

\subsection{The original manual}

Domenico's treatise was the first of its kind, and although it is unknown exactly in which year it was written, it is clear that the surviving copy was written after Domenico had been knighted in 1452 (Smith 1995, Vol. I, 5). The manuscript of De arte saltandi et choreas ducendi is now held in Paris at the Bibliothéque Nationale, although it was originally housed in the library of the Sforza dukes of Milan. The frontispiece on the manual shows it belonged to the Duke of Milan (Brainard 2004c, 427), perhaps given to him by Domenico himself on one of his visits to his court (Wilson 2006, 1). The manual made its way to France after Louis XII captured Pavia in 1499, taking over the contents of the Sforza dukes' library, and transferring them to his own in Blois (Wilson 2006, 1). When it was decided to move the library to Fontainebleu, its contents were catalogued. Domenico's treatise was recorded as "Ung autre en italien couuert de cuyr tanne intit. Liure pour aprendre a dancer" (Wilson 2006, 1). ${ }^{5}$ This new library, known as the Bibliothéque Royale, eventually was included in the Bibliothéque Nationale, which explains its current location (Wilson 2006, 1).

Comments and labels added by librarians are present throughout the text. ${ }^{6}$ Its current catalogue number, ITAL 972, is written on a sticker on the front cover, but other numbers are written too. There is a catalogue number written in Roman numerals alongside the titles of the text (the title is given in both Latin and Italian), and there are also two other numbers -923 and 7747, accompanied by the stamp of the French Bibliotheca Regia. Before the treatise itself begins, there are three

\footnotetext{
${ }^{5}$ Trans. "Another (book) in Italian covered with soft leather, entitled Manual for learning to dance". ${ }^{6}$ This, and the remainder of this section is based on Wilson's study on the manuscript in the Bibliothéque Nationale. All information given is from Sources for Early Dance. 1. Domenico of Piacenza, pp.1-2.
} 
pages of librarian comments written in one of three languages - Latin, Italian or French.

D.R. Wilson has carried out a lot of work analysing the original copy of De arte saltandi et choreas ducendi. From this research we know that the manual was 55 pages, or 28 folios long, with the first and last page both being on the right hand side. Wilson also tells us that each page has been ruled up with 31 horizontal lines and two margins, probably to ensure some consistency in presentation between the scribes, of which he says there were at least six. ${ }^{7}$ This he has determined by the differing nature of the handwriting throughout and by the inconsistent spellings. This is also an indication that rather than copying an original version (although there may have been one), the scribes were writing down what was read aloud to them.

\footnotetext{
${ }^{7}$ For discussion of which hand wrote which parts of the text, see Wilson's Sources for Early Dance1. Domenico da Piacenza, pp.1-2.
} 


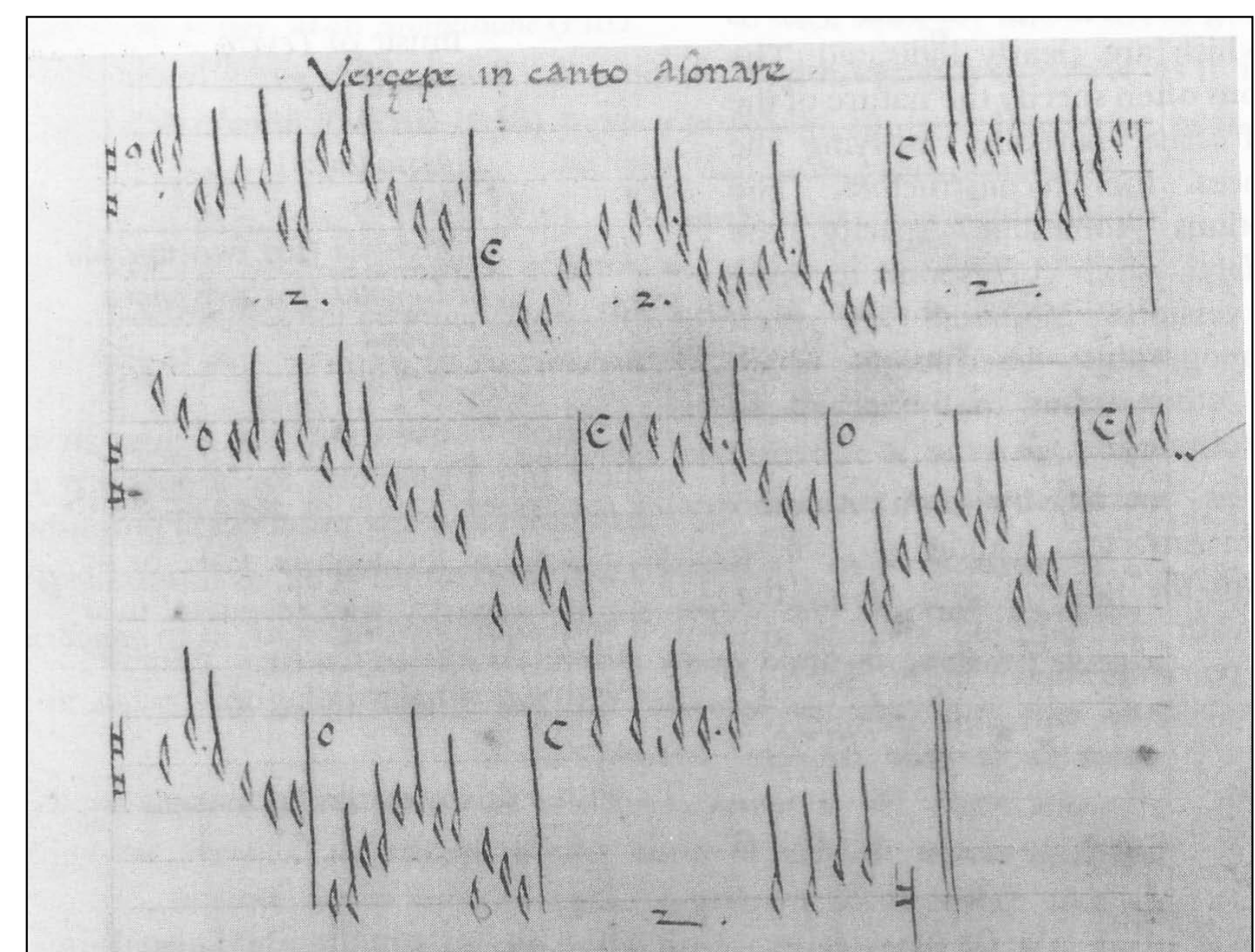

- Vercepe abalo eua in homeni tri.e doe dome. Mprima ua uno homo in anti una dana driedo por uno homo poi una dona epor uno homo dedriedo. fagando tienpr $x_{1}$. di faltearelo cin uno monimento nel partire andaoando tri tr alafila $p$ hoodnne laror luno da laltro p f pathia de pari. uny. por ce afermano tuta.

Ora nota के lo homo के e.dedriedo e quallo or.e in mece fane tut dur in feme tienpr quatro emeco debafadança in for mexuat? zoe dupi dui comencando dalpe finittvo andagzindo denanti un tadoma to lano denanti da lo lato drito de dita dona efa ciendo ditt dui homeni dupy dur inve dpe finittro et unza ve prexa is lo pede drito ficiendo fine dal liniftro tornendo ne

Fig 16: Notation of the ballo Verçeppe from Domenico's De arte saltandi et choreas ducendi, c.1455.

57 
The manuscript is not perfect and indeed it is not even finished. Thirty-five initials are missing, which appear to have been left blank in order for someone to draw them decoratively, as was the first word of the treatise. Some of the missing letters have been noted in the margins, perhaps by a librarian. Also attributed to a librarian are the numbers counting the chapters of the treatise written in the margins. There are mistakes throughout the manuscript, some of which have been corrected by either erasing the error, crossing through it with a line, or drawing a line of dots below it. Other mistakes have gone unnoticed however, such as the "Mettando ti" in folio 5 which appears one line before it should have been written.

Alongside his analysis of Domenico's manual, Wilson has carried out a transcription of the text, in what he considers to be a true representation of the original text. He is not the first to do this as Dante Bianchi had done so in 1963, but modern scholars dismiss the latter's attempts due to the number of mistakes found in his edition. ${ }^{8} \mathrm{~A}$. William Smith also transcribed the manual, and translated it into English. Although some words differ when comparing Smith and Wilson's readings, there are no major discrepancies. In general, their transcriptions are very similar.

Using secondary sources, such as Smith and Wilson's transcriptions, one can reconstruct De arte saltandi et choreas ducendi. It is also useful to compare Cornazano and Guglielmo's ideas with Domenico's, as both reference Domenico as their teacher, and acknowledge his role in the creation of the dances they notate in their texts, as discussed in Chapter Two.

\subsection{The aesthetics of dance}

Domenico's manual is divided into two parts. The first consists of sixteen chapters and a diagram which discuss the theory of dance, and the qualities one should aspire to achieve. De arte saltandi et choreas ducendi is the first written work in the Western world to discuss the aesthetics of dancing (Brainard 2004c, 428). The second part is a collection of Domenico's choreographies. There are descriptions of

\footnotetext{
${ }^{8}$ Errors include printing the same page twice, omitting an entire page, and the very first word of the manual being copied incorrectly (Wilson 1 ).
} 
eighteen balli and five bassedanze included, as well as the music for each of the balli. Domenico stresses how important music is - it is the foundation of dance. He composed his own tunes for the balli "salvo che il canto dela figlia guiliel-mino che e ballata francese" (Smith 1995, Vol. I, 26). Music notation is included with more dances associated with Domenico than with any other dance master (Smith 1995,Vol. I, 5). While each tune given in Domenico's manual is monophonic, iconographic evidence from the Renaissance suggests that more instruments would have been involved in performance, perhaps improvising their parts (Sutton 2004, 351).

The opening chapter in Domenico's manual is a defence of dance as an art and a science. ${ }^{9}$ Domenico's first sentence invokes God and his role in inspiring intellect in human beings. He proceeds to explain how God has given him the gift of dance and the ability to discuss it intellectually. Domenico notes that not everybody agrees that dance is a noble activity, but backs up his own beliefs that it is, with references to Aristotle's Nicomachean Ethics, establishing that so long as it is practised with moderation, dance is an elegant activity for the elite to participate in. He says that with the complicated technique involved in dance (listing misura, memoria, agilitade, maniera, misura di terreno and fantasmata) "questa arte e demostratione zentille de tanto intelecto e fatica quanto ritrovare se possa" (10) and thus is appropriate for the noble class. He furthers this idea in Chapter II by noting that "niuna creatura create che habia in se de natura man-camento de questo motto zentille capace" (10). One must possess beauty to be a practitioner of this art, although he notes that this alone is not enough to make you a good dancer. His next few chapters then discuss the other qualities necessary for a dancer, which I will detail below.

Misura: quickness and slowness, according to the music. Domenico notes that this is the foundation of dance. It is also "la gratia dela mainera de el deportamento de tutta la persona" (12). The third use of the word misura is in reference to misura di

\footnotetext{
${ }^{9}$ Hereafter, all references to the manual are taken directly from Smith's transcription. Page numbers refer to Smith's Fifteenth-Century Dance and Music, Vol. I: Treatises and Music.
} 
terreno, a quality where one must "fa tenire el mezo del tuo motto dal capo ali piedi" (12).

Memoria: The ability to remember all the different steps, both "natural" and "incidental" (terms explained below).

Agilitade and Maniera: Agility and manner of moving. Domenico instructs that one must perform these qualities in moderation and "tenire el mezo del tuo movimento" (12).

Fantasmata: a concept of pausing and then driving the movement, controlled by understanding the quickness and slowness of misura.

Concordantia di terreno: Being aware of where you should be, and where others are. Ensuring you are in the right place at the right time.

Chapters VIII, IX and X of the manual then deal with the steps used in the dances. Domenico lists nine natural movements and three incidental ones: sempio, doppio, ripresa, continentia, riverentia, mezavolta, voltatonda, movimento, salto, (natural) and frappamento, scorso, cambiamento (incidental). Domenico says the three incidental steps are not necessary, but rather are ornamental, and instructs to perform them in the vuodo - they should be performed between tempi (today we would call it the up-beat), unlike the natural steps, which are to be performed in the pieno - within the tempo.

Domenico does not specify how each step is performed, but he does inform the reader of how long each step should take musically speaking. The steps which fill one tempo (the equivalent of two bars) are doppio, ripresa and riverentia. A sempio, continentia, mezavolta, movimento and salto only use half a tempo, a voltatonda requires two tempi. Domenico writes that the three incidental steps only need one quarter of a tempo, and are not to be performed more than once within any given tempo, unless the dancer was particularly gifted, and could perform two 
frappamenti at the speed of an eighth of a tempo. The most frequently used steps are the sempio, doppio, ripresa and voltatonda. Of the ornamental "incidental" steps, the frappamento is used most often with these four steps. The scorsa is used when one dances a mezavolta at the end of a doppio, while a cambiamento is only used in a bassadanza.

The remaining six chapters are all discussions of music, and how one should dance to each misura. In Chapter XI, Domenico informs the reader that to dance, one must be able to recognise each particular misura, and know which movements to use according to this. One must acknowledge the differences in the silence and the sound in the music and know how to fit the dance with this. One must also measure "el movimento del corpo cum la prompta del pede" (16) - by this he means that in order to look elegant, one's bodyweight must move in accordance to his step size.

Domenico's multiple discussions of the use of misura in dance support his belief that it was the most fundamental technique involved in dance. Of the particular misure themselves, he states there are four: bassadanza, quadernaria, saltarello and piva. As a ballo usually involved more than one of these misure it was essential for a dancer to be able to recognise each misura and know which steps were suitable to perform to each rhythm. It is therefore crucial for me to examine these misure in detail before I attempt to reconstruct some dances. 


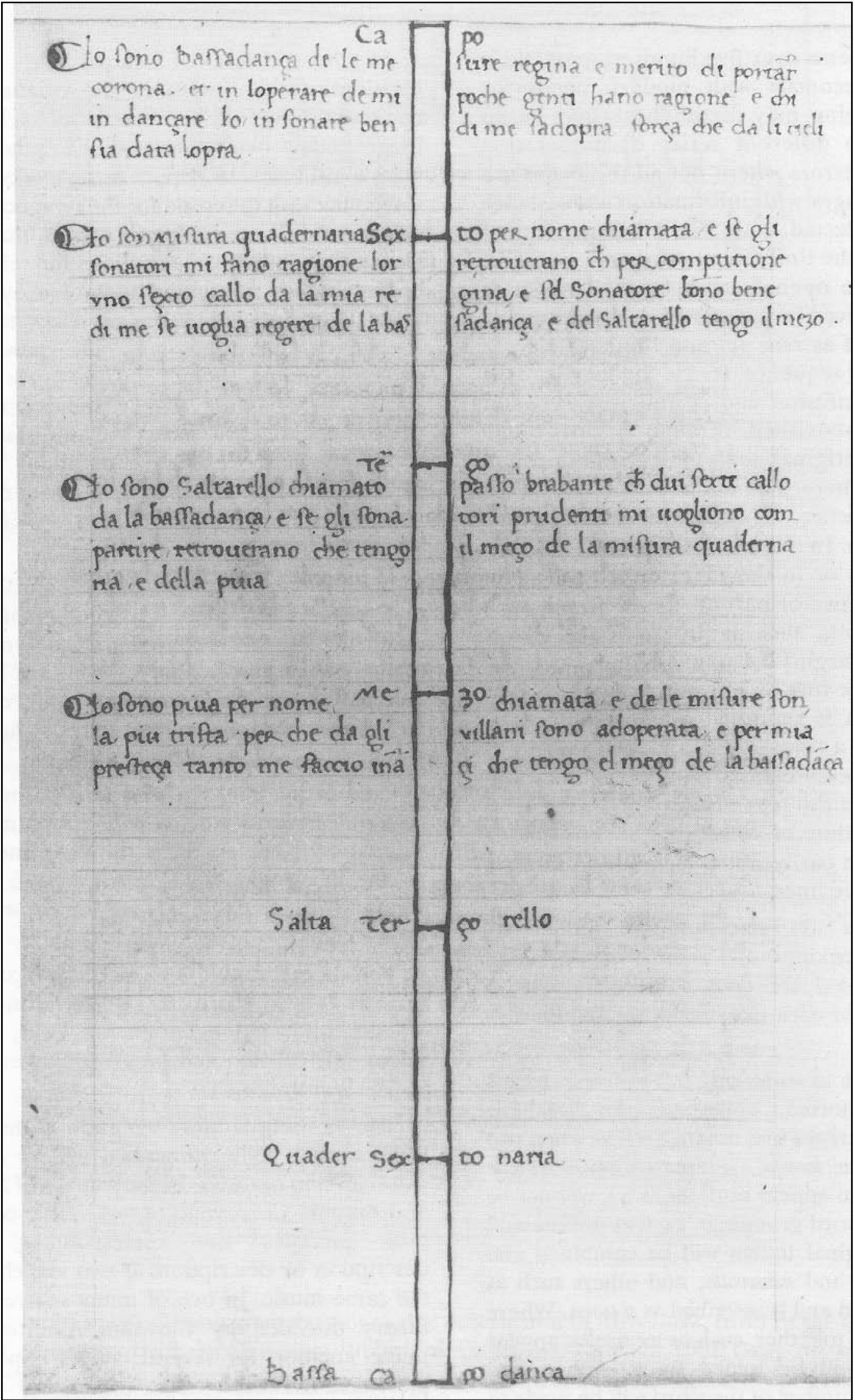

Figure 17. Diagram of the misure from Domenico's De arte saltandi et choreas ducendi, c.1455. 


\subsection{The four "misure"}

Bassadanza: This is what Domenico calls "dele mesure regina" (18). It is the slowest of all the measures, and musically speaking, it is major imperfect. In his diagram, Domenico notes that many people do not understand the bassadanza, but "chi in dançare lo in sonare ben di me s'adopra força che dali cieli sia data l'opra" (18). When performing a bassadanza one is to begin the tempo in the vuodo and complete it in the pieno. A musician playing a bassadanza tune will open with the soprano rather than the tenor, and this is the difference between the vuodo (the soprano) and the pieno (the tenor). A bassadanza is lead with movimento, then a step in keeping with the vuodo/pieno relationship.

Domenico says a bassadanza may be danced in five different ways. The first two are natural: one can perform a bassadanza step that fits perfectly with the misura, or one can perform two piva steps (two doppi), as "la mexura dela piva cala sesti tri dala bassadanza" (20). The other three are more difficult. To do a quadernaria movement in a bassadanza tempo, one must perform a doppio with a frappamento. There are two different ways to perform saltarello steps in bassadanza measures. The first is to simply dance a tempo of saltarello, but it will take a lot of control, as it will be very slow. Alternatively, one can dance two steps of saltarello in one tempo of bassadanza, but it will be very fast, so only a skilled dancer will be able to do this.

Quadernaria: This is one sixth faster than a bassadanza, and written in minor imperfect. In opposition to the bassadanza, a tempo of a quadernaria begins in the pieno and finishes in the vuodo. The tenor and the soprano both begin at the same time in this misura, and the beats of the tenor are "piu equale per distantia" (18) in the quadernaria than in the bassadanza. The quadernaria is also opposite to the bassadanza in that one steps first, to achieve the opening pieno.

There are four different ways a quadernaria can be danced. The natural way is to dance a doppio followed by a frappamento. The second alternative is to dance a bassadanza step, but this will be faster than a normal bassadanza step, and goes against the phrasing of the music, so it is difficult to do. The third is to dance a 
saltarello step in a tempo of quadernaria, but as the saltarello is a faster dance, it will seem slow here. The final way is to put two piva movements in one tempo of quadernaria - this is the way often used in festivals.

Saltarello: This is in major perfect and a sixth faster than the quadernaria, therefore a third faster than the bassadanza. Domenico talks of it as a "Brabant" step-unit, (Brabant is a region near Holland). He states that the saltarello "ha lo suo nascimento dala bassadanza perche se ricomenza el suo tempo in lo vuodo como la bassadanza Ed e de mazore perfecto" (18).

A saltarello has five different styles. The first is its natural arrangement, in which the saltarello step fits in perfectly with the music. The second is to perform one tempo of bassadanza in two tempi of saltarello. Domenico notes this is not for the inexperienced, as it will be challengingly slow. The third way is to perform one bassadanza tempo in one tempo of saltarello. This will make it a very fast step. The fourth way is to dance a tempo of quadernaria in a tempo of saltarello, but this too will be fast. The final style is to perform two piva steps in one tempo of saltarello. This, Domenico says, is beautiful but difficult. It is very fast, and goes against the music.

Piva: This is three sixths faster than a bassadanza. Domenico says this is "la piu trista" (20) of the misure as "dagli villani sono adoperata" (20). This tempo comes from the quadernaria as it starts in the pieno and is in minor imperfect.

The piva can be performed in four different ways. The first, as in all the other styles, is to perform it as the music suggests: a piva step to piva music. Alternatively, one may perform one bassadanza movement, one quadernaria movement or one saltarello movement, all of which must be performed over two tempi of piva.

\subsection{The language of dance}

Now that the manual's contents have been outlined, it is interesting to focus on the language and style Domenico uses to explain his work. To write down dance - to put 
movements and physical concepts into words, Domenico had to create a new technical vocabulary. Part of this vocabulary was created by involving everyday words, with their everyday meaning. Aere for example, in one definition, meant "a countenance, a looke, a cheere, an aspect, a presence, or appearance of a man or woman" according to the earliest Italian-English dictionary (Nevile 2004, 77). The dance masters use this word to describe this same quality, but in relation to dance, not just everyday life.

Other words in this newly created vocabulary were taken from other arts (Nevile 9). A poet writing about Pisanello at Urbino in 1442 used the words misura, maniera and aere to describe Pisanello's painting (Lockwood 1984, 72). Some of Domenico's terms are also borrowed from treatises about painting. In his art manual, Leon Battista Alberti talks about how figures painted with extreme gestures indicate their low social standing. Similarly, Domenico warns his readers that to appear noble, one must take care not to make excessive movements (Nevile 2004, 98). Some of the words used by Domenico also derive from music. Misura in particular is largely a music term, one that Domenico uses in its musical sense, but also in the sense of moderation in dance. Aere was also used in music, used both to describe particular qualities in how one played the music, and as a name for a type of melody (Lockwood 1984, 72).

To help his readers understand some of these techniques, Domenico uses beautiful imagery. To develop his description of the concepts of agilitade and maniera and help get his point across that one must not move with excessive gestures, he writes:

cum tanta suavitade che pari una gondola che da dui rimi spintan sia per quelle undicelle quando el mare fa quieta segondo sua natura. Alçando le dicte undicelle cum tardeza E asbasandosse cum prestesa (12).

At once, the reader can envisage the smooth gliding of the gondola, and can more readily understand the nature of the movement that Domenico intends to be performed. Chapter $\mathrm{V}$ of the manual also contains striking imagery. In explaining 
the technique of fantasmata, Domenico writes that one must appear "ha-ver veduto lo capo di meduxa[...]cioe che facto el motto sii tutto di piedra in quello instante et in instante mitti ale como falcone che per paica mosso" (12).

Fantasmata is thus obviously a difficult technique where one must learn to freeze momentarily, then move the action forward with a forceful drive.

As well as similes, Domenico uses proverbs to get his ideas across. In Chapter II he uses the proverb "chi idio fece bello non fece tucto povero" (10) to convey his belief that "niuna creatura creata che habia in se de natura mancamento de questo motto zentille capace" (10). In Chapter XI, he employs three different proverbs in his discussion of music and how difficult it is to find good musicians who fully understand how to play dance music. He writes all three in a row: "omni oxello non cognosce el grano" so it is "necessario viver le oche aprono" because the "ignoranti viveno apresso le divitie" (16).

\subsection{Classical references}

The Renaissance saw a renewed interest in classical antiquity, and so it is of no surprise that references to ancient Greek and Roman beliefs appear in Domenico's treatise. The act of writing a treatise itself in the style that the dance masters did, is based on models from classical authors (Sparti 1993, 373). These ancient authors were not only used as a model, but also as a source of evidence, a way for the dance masters (and other art-based intellectuals) to give a sense of authority to their ideas (Sparti 1993, 375). Domenico uses Aristotle's Nicomachean Ethics, which he has obviously studied in great detail, to back up several of his ideas. Domenico cites the second book and the tenth book on the very first page of his manual. He notes that in the second book of his Ethics, Aristotle writes that any movement taken to the extreme is bad, using this to support his idea that dance should be performed in a moderate fashion. Domenico's reference to the tenth book is very brief: "E bene che'l savio Aristotel tractasse del motto alquanto in lo $x^{\circ}$ del heticha" (10). Apparently this was enough of a reference to provide his work with a sense of authority (Sparti 1993, 376). 
Even some of the techniques Domenico discusses can be traced back to classical antiquity. Measure and Memory were important concepts in Prudence, one of Aristotle's five "modes of thought or states of mind through which truth is reached" (Sparti 1993, 376). The concept of fantasmata, with its sudden freezing of movement is linked to Greece too, as supported by Domenico's reference to the myth of Medusa, who could turn people into stone by looking at them. Other classical references are apparent in the names of dances, such as Domenico's "Giove", named after the chief Roman god.

\subsection{Domenico's choreographies}

Up to now we have discussed the first part of Domenico's manual in which he deals with the technique required to dance well. Now we can turn to the choreographies themselves, and examine the nature of his dances. The second part of De arte saltandi et choreas ducendi is a compilation of 23 of Domenico's choreographies, five of which are bassadanze, the other eighteen are balli. The balli are all accompanied by musical notation, the bassadanze are not. While the bassadanze can have "quanti si vuole" (64) dancers, as they are performed "ala fila" (64), the balli all specify exactly how many performers can participate in each dance. Most commonly, the balli are for "homo uno con la dona" (50) or for "homini dui et una dona in mezo" (42) but others have stranger combinations such as Tesara, which is composed for six men and four women, or Sobria which is for five men and one woman.

This latter ballo is one of many that demonstrate a play between the sexes. Verçeppe is another to do this. In this dance, three men and two ladies start in a line, then dance weaving in and out of each other, and circling one another to illustrate this interaction between man and woman. Others pursue this play further and become quite pantomimic. Gelosia, for example is a love game played by three gentlemen, who flit between the three women, beginning the dance with one, seducing a second and then ending up with the third lady (Pontremoli 2009, 35). 
Some of these dances are so pantomimic that Brainard labels them "mini dance dramas" and as such, they are "the first two genuine ballets in the history of art" (Brainard 2004c 427). Cornazano writes in his manual about how "il fondamento di proposito" is present in all balli, but to a greater extent in some, such as Mercantia and Sobria (Pontremoli and La Rocca 1987, 198). Sobria is a dance for four men and one woman, in which the men try to woo the woman, who in turn rejects them. The men then try a second time while the lady's back is turned, and when she discovers them she is fuming, so that the men dance away quickly (Sparti 1986, 347-48). Mercantia is the opposite. Cornazano introduces it as a "ballo appropriato al nome; che una sol donna danza con tre homini e da audientia a tutti, gli ne fossero pure assai, come quell ache fa mercantia d'amantia" (Pontremoli 2009, 35).

The inspiration for other dances can be determined by their titles. Belfiore, Belriguardo and Lioncello can all be associated with the Este family. Belfiore is the name of their villa which had been built at the end of the fourteenth century and Belriguardo is the name of their country villa (Lockwood 1984, 71). The Este family was obviously very involved in the dance scene and their passion for it is further illustrated by the fresco in Belriguardo that portrays noble people dancing at court (Nevile 2009, 26). The third dance associated with this family, Lioncello, invokes "the same fanciful association of Leonello with the lion, the symbol of courage and wisdom, that is used by Pisanello for his portrait of Leonello in the wedding medal of 1444" (Lockwood 1984, 71). The dance may even have been named thus as a result of it being the dance created for Leonello's wedding, although unfortunately this is not known for sure.

\subsection{Conclusion}

Domenico's manual was revolutionary. As the first person in the Western world to write down dance, Domenico created a way to articulate dance steps and techniques by creating a specialist vocabulary that was flexible enough to absorb terms from other arts as well as coin original names. Influenced by the humanist thinking of the Renaissance culture that saw manuals written on a multitude of social, political, cultural and educational themes in order to place importance on 
them within society, Domenico sought to raise the reputation of dance by writing De arte saltandi et choreas ducendi as a defence of dance as both an art and a science.

Interestingly, Domenico's manual is not too different from a classical ballet one that might be written today. Just as fifteenth-century court dance had a full vocabulary, so does ballet. Classical technique books have been written since 1820 when Carlo Blasis set his ideas out in his work Traité élémentaire, théorique, et pratique de l'art de la danse ("Elementary, Theoretical, and Practical Treatise on the Art of the Dance") (Franko 2011, 325). This type of book is very similar in nature to the first part of De arte saltandi et choreas ducendi. The only major difference is the use of diagrams in classical ballet manuals to demonstrate techniques. As classical ballet is a lot more complex than fifteenth-century court dancing, these later manuals are obviously a lot more comprehensive, but the fundamental idea of using a technical vocabulary to explain techniques in written form to a dancer is essentially the same.

Similarly, the choreographies written in the second half of Domenico's manual can be seen as early predecessors of classical ballet syllabi. Five and a half centuries later, many ballet exercises or dances are notated in the same way Domenico notated his: by naming the step, giving the direction in which it travels and the foot with which the step begins.

The main difference between Domenico's manual and those of classical ballet is that ballet is so universally acknowledged and practised today that any dancer could pick up a manual and recreate a dance written in it, as all trained ballet dancers understand the step names and techniques. Unfortunately, as fifteenthcentury court dance is no longer a practised art form, a modern reader does not immediately know how to perform a step by just reading its name. Just as the writer of a ballet manual assumes the reader already knows how to perform each step, so did Domenico and thus he did not explain exactly how each step should be performed. 
In the next chapter I will address this issue and evaluate how difficult this makes it to reconstruct Domenico's choreographies. By attempting to perform the dances after having learned techniques and routines only by reading De arte saltandi et choreas ducendi, I will be able to determine just how effective Domenico's method of notating dance remains to this day. 


\section{Chapter Four: Domenico's choreographies and issues of reconstruction}

\subsection{Introduction}

In Chapter One I gave a brief overview of some different dance notation systems, and discussed the flaws present in each of them, as well as pointing out the limits of video preservation of choreography. I suggested that as most choreographers and teachers today tend to use word descriptions to notate their dances, Domenico, the first person to use this method of dance notation (or any method of dance transcription for that matter), laid the foundations for the most accessible and lasting way to preserve dance in Western culture. After having established, in Chapters Two and Three, the role of dance in fifteenth-century Italy, the influence of Renaissance culture on both Domenico's writing and choreography, and the style and technique of court-dance practices, it is time to reconstruct some of these dances, in order to find out exactly how effective Domenico's system was.

I have chosen to examine three different dances, all of them balli, in order to provide a general assessment of Domenico's dance writing. These three balli are contrasting in theme, style, floor pattern and general nature. I have decided not to examine any bassadanze, because Domenico did not provide music for these, thus making any attempt at reconstruction more difficult. Moreover, as they were processional dances and therefore had no floor pattern or interaction between dancers, the bassedanze are less interesting to examine.

I will work through the chosen choreographies and note the difficulties I face in trying to reconstruct an entire dance from only the text on the page. It should immediately be noted that Domenico was not writing for a readership that had no first-hand experience with his style of dancing, but rather his manual was conceived as a reminder for those who were taught by him in person. Thus, we can assume that it will be more difficult for a modern dancer to reconstruct any given dance from his manual today than it would have been for a dancer in fifteenth-century 
Italy. Details may have been left out by Domenico as he assumed his readers would already understand them as standard practices of the Italian court dance style. In considering his writing system, I must thus assess which problems are due to flaws inherent in his methods of dance notation and which are simply the result of five and a half centuries time difference.

I have chosen Anello, Lioncello Novo and Gelosia as exemplars for my reconstruction and analysis, as all appear to have been popular dances that were recorded in many of the fifteenth-century Italian dance manuals that came after Domenico's. This is an important element for my selection, as I will be able to turn to other texts for supporting evidence if I face any vague or ambiguous parts in Domenico's work.

I will also need to examine some secondary sources in order to recreate the dances, as none of the primary authors specify exactly how to perform any given step within the context of Domenico's choreographies. Both D. R Wilson and Madeleine Inglehearn have produced texts which describe the steps as they believe they were performed, with both scholars having done extensive research on the fifteenthcentury manuals, and additionally, on manuals of the late Renaissance where dance masters such as Caroso and Negri explain more in detail the performance of individual steps. I will therefore refer frequently to their works as aids to my reconstruction of Domenico's dances.

\subsubsection{The ballo "Anello"}

This is a transcription of the dance "Anello" as Domenico wrote it in his manual De arte saltandi et choreas ducendi. ${ }^{10}$

Anello a balo e va homini dui e done doe.

Mprima fano diti homeni e done moti oto di saltarelo in mexura de piva andagando in ciope doe large l'una dal'altra

${ }^{10}$ As transcribed by Smith, 1995 Vol.1, 42-44. 
per spacio de pasi quatro e in code diti tienpi li homeni lasa le done rimanendo in quadro zoe che cascaduno de loro se guardi nelo volto e cosi le done afirmandose.

Nota che tutti dui li homini in instante fano uno movimento e le done ge rispondeno como uno altro poi li homini vano L'uno contra dil'altro fazando tempi dui de saltarello comenzando col pe sinistro finiendo cum lo drito cum mezavolta suso dicto pe ritrovandose haver cambiato posta afirmandose poi le done fano uno movimento e li homini li respondeno como uno altro scambiandose poi dicte done per quello modo feçeno li homini afermandose.

Apresso nota che li homini fano uno movimento e le done ge rispondeno como uno altro possa li homini dano una voltatonda neli logi suoi dove li consiste uno dopio afirmandose. Le done fano uno movimento rispondendo ge li homini como uno altro facendo dicte done la simel volta che feceno li homini afirmandose.

Ancora nota che li homini fano tempi quatro de piva movandose suso lo lato drito andagando de drieto ale done Scambiando poste afirmandose e le done li respondeno cum lo simele scambiando poste e afirmandose.

Or nota che li homini fano uno movimento e le done li rispondeno como uno altro fazando li homini pur un altro movimento rispondando ge le done como uno altro facendo dicti homini y una ripresa sul canto drito pigliando le lor done per mano como de prima et e finito. 

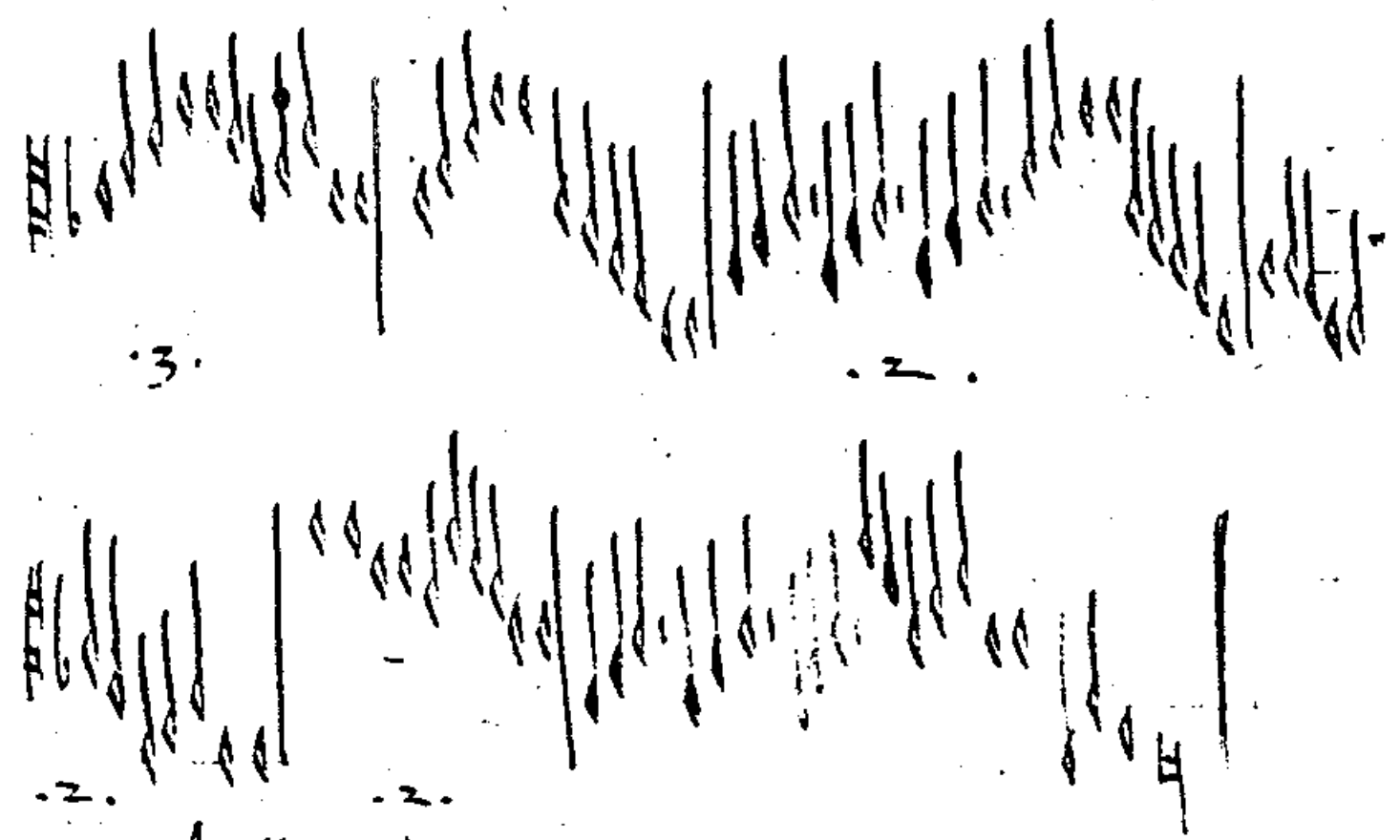

Arello abalo eur homini dui edone dox.

Mpima faro dit homeni edone mot oto di caltarelo

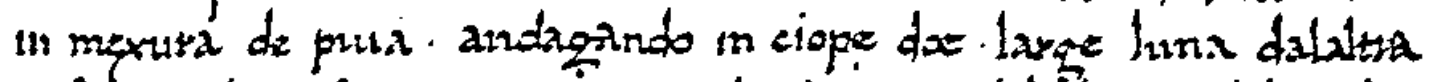

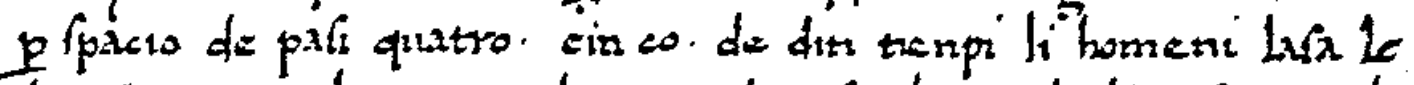

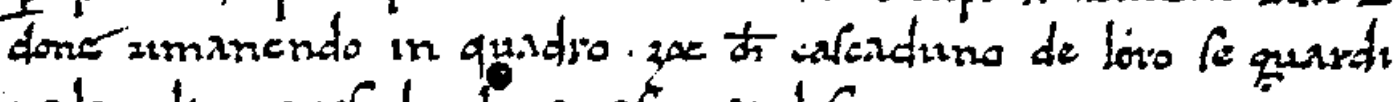
nelo walto ceori le done a firmuindore.

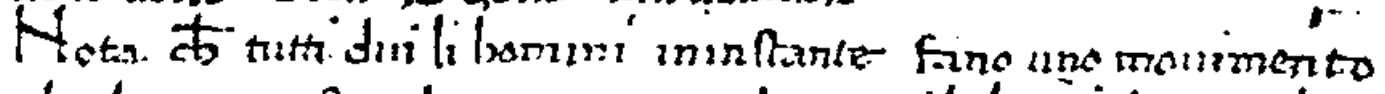

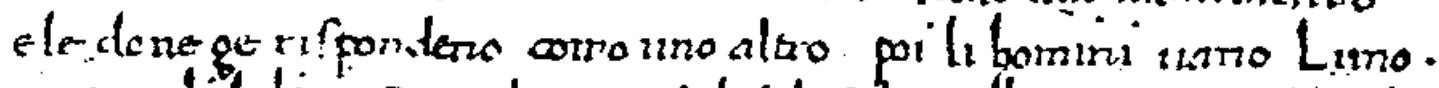

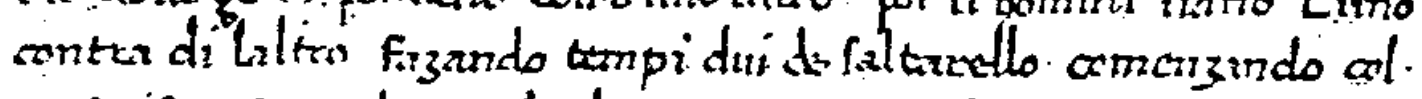

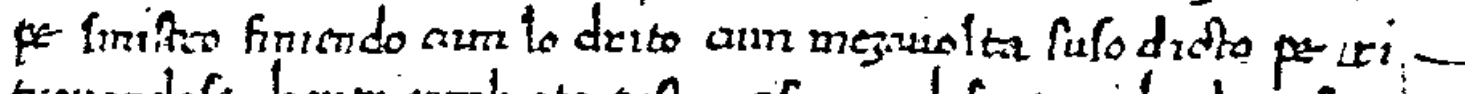

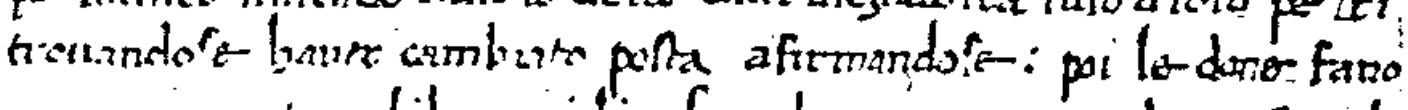

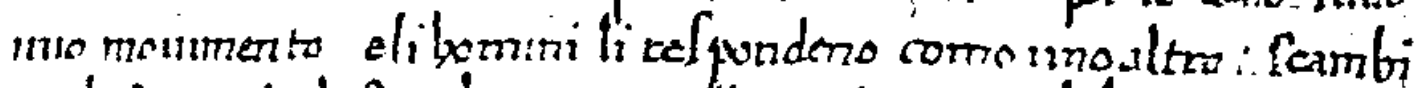
andele pai disto done pquelle mado foco li bomiri afirm sndore.

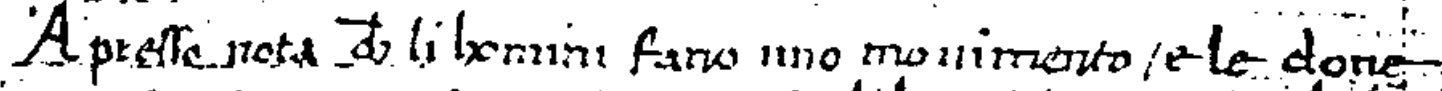

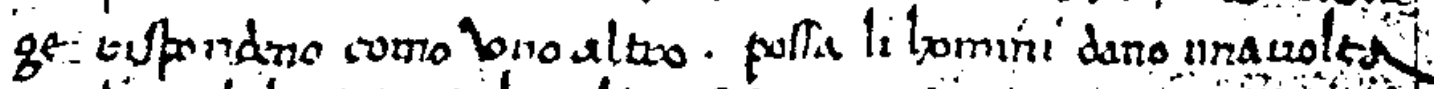

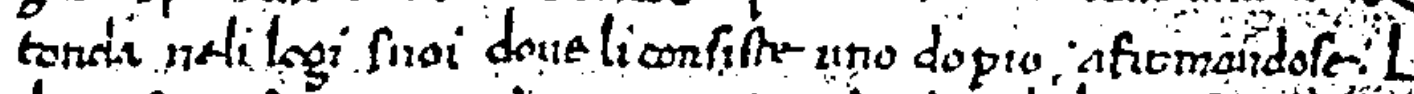

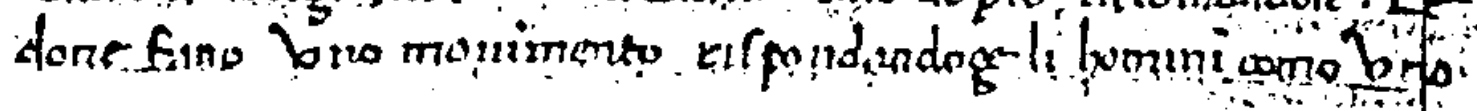

Figure 18: Notation of the ballo "Anello" from Domenico's De arte saltandi et choreas ducendi, c.1455. 
Domenico describes his choreography in a simple manner, his instructions are concise and to the point. Unlike the introductory chapters in his manual, Domenico does not use any similes or imagery, nor examples from classical works to get his ideas across. Instead, his instructions are written almost as a list of steps with additional information such as which foot to begin with, or which direction to travel. Unfortunately this is not always the case, and some instructions remain vague, as I will detail later. Others, however, are quite specific, such as the instruction to be "andagando in ciope doe large l'una dal' altra per spacio de pasi quatro" (Smith 1995, Vol.1, 42), indicating the precise spacing between the couples.

Domenico seems to start each new section of the dance on a new line of text. Most sections involve the women repeating a sequence or step that the men have already performed; instead of spelling the whole sequence out again, Domenico tends to just write "rispondando ge le done como uno altro" (Smith 1995, Vol.1, 44). This is a form of shorthand for Domenico so that his description does not become too long: rather than restating each step again, he simply instructs the women to repeat what the men have done. This instruction occurs four times within the choreography of Anello, and twice in the reverse: twice the men are instructed to "rispondeno como uno altro" (Smith 1995, Vol.1, 42) and repeat what the women have, in these circumstances, performed first.

For a reader of modern Italian Domenico's descriptions can prove quite difficult, due to the archaic language. Once a reader or potential performer overcomes the linguistic difficulties however, the dance becomes reasonably clear to follow. Domenico's instructions are short and concise with no added descriptions other than the step name, the number of times each step is to be performed, the beginning foot and the direction of travel. The description of the Anello is representative of Domenico's style in notating dance: all his notations are done in the same manner, with short, concise instructions and only basic, necessary details provided. This style was followed by later dance writers, such as Guglielmo and Cornazano, who went on to write in the exact same manner in their manuals that followed De arte saltandi et choreas ducendi. Not only that, but in a modern 
syllabus of dance forms such as classical ballet today, a similar style is used: short, concise instructions made possible by a developed technical vocabulary. Dance has become more complex since the fifteenth century, so naturally descriptions tend to be more extensive and intricate, as the steps themselves are, however the manner in which they are described remains the same.

In short, the Anello is a brief dance choreographed for four people, two men and two women, in the quadernaria misura. It is a simple dance, where most of the sequences are performed by one gender and then repeated by the other. The title Anello means "ring" and it seems this is due to the nature of the formations in the dance, as I will discuss later.

\subsubsection{The problems in reconstructing "Anello"}

In my reconstruction of Anello, I have come across four major problems. The first and main issue is that none of the steps are described, just listed in the order they come in the routine. Domenico would have assumed that his readers knew how to perform any given step just by naming it, just as a writer of ballet today would assume that their readers, who were dancers, would know what a demi plié or an arabesque are. Unfortunately, since Domenico did not fully explain how to perform them in his manual either, nor did his more immediate followers Guglielmo or Cornazano, nobody can be sure exactly how to execute the steps. Wilson and Inglehearn's works of interpretation can help us to establish possibilities, as both scholars have done extensive research into how these fifteenth-century steps may have been performed.

Other problems I have encountered in my understanding and reconstruction of Anello are due to some vague notations on Domenico's part. For example, there are places where he neglects to specify which foot to begin a step with, or which direction to travel a sequence. I will examine these problems one by one and I will draw conclusions as to the degree of difficulty one may find these days in reconstructing this particular dance. 


\section{Problem 1: Domenico does not properly explain how to perform steps}

According to other sources, this is how the steps were performed (in order of appearance in the dance):

Saltarello: $^{11}$ There is a lot of controversy over the nature of a saltarello. As a step used in many dances to different misure and in seemingly different ways, it is difficult to find a standard way of performing it so that it fits into each of these dances. In Chapter XIV of his treatise, Domenico writes: "I moto/ del saltarello e uno dopio cum uno salteto" (Smith 1995, Vol.1, 24). Linguistically speaking, the word salteto implies a small jump of some kind, deriving from the verb saltare. It is then necessary to figure out what kind of jump this is meant to be and where it fits in with the doppio.

Because of the way it is phrased, "uno doppio cum uno salteto" seems to suggest the salteto goes at the end of the doppio. However, Domenico does not specify this, so it could go somewhere in the middle, although this seems very unlikely. In his own work Libro dell'arte del danzare (1455), Cornazano does not mention the salteto at all in his description, saying a saltarello step "consiste solo di passi doppi, ondeggiato...e campeggiato" (Wilson 2003, 44). Wilson believes that he did not mention the salteto as Cornazano did not think it was necessary: his manual was written for the young Ippolita Sforza, who had been dancing in public since age four, and would have known how the step was performed. This implies that the salteto was at the end of the step, as surely Cornazano would have mentioned it if it was somehow incorporated into the standard doppio step.

In Anello, Domenico writes that the saltarelli start on alternating feet. Thus, it seems that the most likely type of salteto that would have been attached to the end of the step is a hop, allowing the dancer to remain on the same supporting leg, with the other leg lifted and ready to begin the next step. As Wilson reminds us, in traditional Italian folk dance the saltarello consisted of three steps and a hop, so it

\footnotetext{
${ }^{11}$ Unless otherwise referenced, discussion of this step is based on Wilson's The Steps Used in Court Dancing in Fifteenth-Century Italy 44-46.
} 
is possible that the step Domenico used was derived from this but performed in a more dignified manner.

Inglehearn describes several different types of saltarello steps, explaining that because the descriptions in the Renaissance manuals are "too vague to interpret accurately, it is best to let the rhythm of the music dictate a suitable step, bearing in mind that saltarello means 'a little leap or spring'" (Inglehearn 1981, 9). She then proceeds to instruct the reader how to do a 'Saltarello A' which can be done in triple time only, a 'Saltarello B' which is done in duple time, a 'Saltarello C', also in triple time, a 'Short Saltarello' done in duple time and a 'Saltarello Todescho' (in this case labelled so by the dance masters) (Inglehearn 1981, 10-11). In her interpretation of Anello, the introductory saltarelli are saltarelli B, which she describes as follows (Inglehearn 1981, 10-11):

\section{Bar 1. $\quad$ Beat}

1 Step forward on the flat of the left foot

2

3 Step forward on the flat of the right foot

4

Bar 2. 1 Step forward on the flat of the left foot

2 Spring onto the right toe

3 Step forward onto the left foot

4

What Wilson calls a standard saltarello (three steps and a hop), Inglehearn calls a saltarello todescho, justifying her decision to stray from Cornazano's vague description of a saltarello todesco as "two simples with a little ripresa executed after the second side step", because todesco means "German" and in sixteenthcentury notations of the Almain dance (also meaning "German") this is how the step is performed (Inglehearn 1981, 11). The second time Domenico instructs his reader to do a saltarello in the dance Anello, this is how Inglehearn believes it should be performed. 
Movimento: $^{12}$ The word literally means "movement", but a more technical meaning is assumed in the context of a ballo. There seem to be two different modes of employing a movimento: it could be used as an introduction to a saltarello sequence, or as part of a "dialogue" between male and female dancers, in a call and response situation. In Anello, it is the call and response version of a movimento that is used. Several times throughout the dance, the men perform a movimento and the women respond, as was generally the case in Domenico's dances. Despite the presence of both male and female dancers, Cornazano notes that the movimento was "honestissimo" (Smith, 1995, Vol. I, 89), meaning that it was acceptable to perform it in public.

No real description is given on how it was performed. It seems to stay fixed on the spot, with no steps involved. Domenico was the only dance master to use the word movimento in his dance descriptions. This movement seems to have progressed into the alzade and scossi found in later manuals. This suggests that maybe the movimento involved a rise onto the toes and/or a movement of the upper body. Inglehearn describes it as doing both. She says it is a "rise on the toes without moving the feet and at the same time turn the body from the waist to take the left shoulder back" then "lower the heels and straighten the shoulders" (Inglehearn $1981,9)$. This seems like a reasonable interpretation.

Mezavolta: ${ }^{13}$ This word means 'half-turn', describing exactly what this step was. It could be performed in three different ways: as a step on its own, as a way of adding a half turn to another step as given by the dance master, or as a quick movement added to the end of one step linking it to the start of the next. Because of the phrasing of Domenico's instructions, it seems that the mezavolta in Anello is an example of the third type discussed above. Domenico instructs his readers to "fazando tempi dui de saltarello comenzando col/ pe sinistro finiendo cum lo drito cum mezavolta suso dicto pe" (Smith 1995, Vol.1, 42). Because the mezavolta is to

\footnotetext{
12 Unless otherwise referenced, discussion of this step is based on Wilson's The Steps Used in Court Dancing in Fifteenth-Century Italy 31-33.

${ }^{13}$ Discussion of this step is based on Wilson's The Steps Used in Court Dancing in Fifteenth-Century Italy 27-31.
} 
be accomplished "on the said foot", it suggests that the half turn would be performed at the end of the last saltarello: if we are therefore going to assume that a saltarello is comprised of three steps and a hop, it would mean that the dancer performs a half turn on the hop of the second saltarello.

Voltatonda: As indicated by the name, this is an instruction for a full turn. Wilson says that it "is not itself a step, but a manoeuvre to be carried out using other steps that are ordinarily specified in the text" (Wilson 2003, 55). In the case of Anello, Domenico tells us it is a doppio that is to be performed as a full turn.

Piva: Cornazano writes that this "non e altro che passi doppi ettegiati: e accelerati per presteça di misura che concita el balladore a quello" (Wilson 2003, 10). He also writes that the doppio is the only one of the natural steps that may be used in the piva, because the music is so fast. Inglehearn's interpretation thus seems reasonable (Inglehearn 1981, 11):

Beat

1 Rise on the toes on the upbeat and step forward on the left toe

2 Step forward on the right toe

3 Step forward on the flat of the left foot bending the left knee on landing 4

The fact that she has the first two steps performed on the toe seems plausible to me, as it is much easier to go faster if one is on one's toes, rather than on flat feet. The flat foot on count three, and then rest on four also seems likely, as it gives the dancers a brief moment to ground themselves before beginning again - it adds some control to the step.

Ripresa: ${ }^{14}$ Although a term used in dances throughout France and England as well, the Italian ripresa seems to differ from these as it travels sideways, rather than

\footnotetext{
${ }^{14}$ Unless otherwise referenced, discussion of this step is based on Wilson's The Steps Used in Court Dancing in Fifteenth-Century Italy 37-41.
} 
backwards. This has been discerned by scholars who have examined the dances and noticed that in many of them "dancers find themselves facing one another at opposite ends of the floor and perform a pair of riprese, one on the left foot and the other on the right: the distance between them, as measured by subsequent steps, remains unchanged despite this manoeuvre" (Wilson 2003, 37). It seems to have been a slower move than a lot of the others. Although a sempio is practically the same as a ripresa, but travels forwards rather than sideways, a ripresa takes a full tempo, whereas a sempio takes only half. A ripresa is thus a step to the side, followed by a close.

\section{Problem 2: Details regarding the floor pattern are vague}

The fact that Wilson and Inglehearn have interpreted the floor pattern in Domenico's Anello in quite different ways suggests that his instructions are not entirely clear. Domenico does not specify where the opening saltarelli are supposed to travel, saying only that there are eight of them, performed as two couples, with one couple four steps behind the other. As mentioned in Chapter One, it was common for balli to have an introductory saltarello section, used by the dancers to enter the room and position themselves for the remainder of the dance. Therefore, it may not have been deemed necessary for Domenico to instruct his readers where to dance these saltarelli, as they may very well have assumed it was an entrance step.

This, however, is a minor imprecision in comparison to the next instruction. Inglehearn has interpreted the instruction to face one another as the men facing the women (Inglehearn 1981, 26), whereas Wilson has assumed that the men would face each other diagonally and the ladies would do the same (Wilson 1999, 17-18), as I illustrate in my diagrams below:

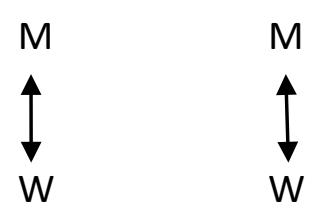

Inglehearn
W

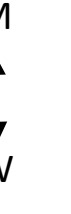


This one detail changes the whole format of the remainder of the dance. The saltarelli in section two of the dance would thus be performed exchanging places in these differing ways:

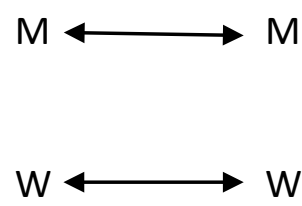

Inglehearn

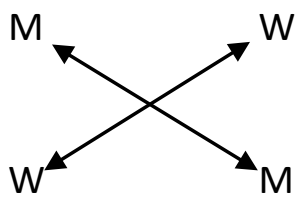

Wilson

Similarly, the pive would then be performed by the men moving behind the ladies in these ways:

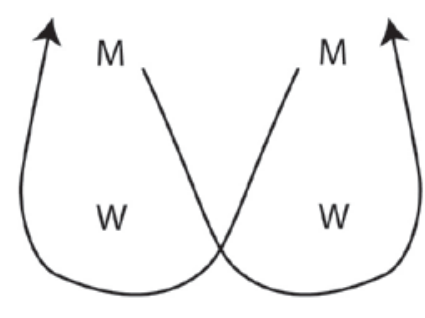

Inglehearn

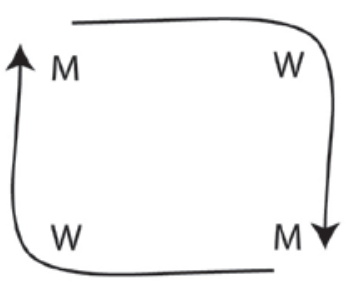

Wilson

Having danced both versions through, I agree with Wilson's interpretation. The dance feels much more like a shared event in his version - shared among all four dancers, not just between partners, as it seems to feel in Inglehearn's version. The figures in Wilson's version are also more supportive of the title Anello or "Ring". The formation becomes more of a circle when all the dancers are facing inwards, and the piva part in particular is much more reminiscent of a ring in Wilson's version than in Inglehearn's. Guglielmo's own wording of the instruction for this part of Anello suggests explicitly this ring formation, as he notes that "gli uomini incontro l'uno all'altro et il simile faciano le donne" (Smith 1995, Vol. II, 12), making it clear that the men should be opposite each other and so should the ladies. 


\section{Problem 3: Which foot to use?}

On some occasions, Domenico remembers to instruct his readers on which foot to begin with, but other times he does not. The opening saltarelli for example are not given a starting foot. Five other sources that include Anello, attributing it to Domenico, explicitly state that one should begin with the left and end with the right foot (Smith 1995, Vol. II, 12). ${ }^{15}$ The two other instances where Domenico leaves the reader unsure as to which foot to begin with are the voltatonda and the piva. Other Renaissance dance manuals confirm that these are performed "voltando si dal lato mancho" (in the case of the voltatonda) and with the left foot first (for the piva) (Smith 1995, Vol. II, 14-15). It seems that most steps in all of the dances begin with the left foot first. Again, it may have been a practice which Domenico simply assumed his readers would have known, not deeming it necessary to specify it for every step.

\section{Problem 4: Posa}

In section three of Anello, Domenico states that the men do a movimento, and then the ladies respond with another possa. It is unclear what a possa (or posa) is. Domenico does not include it in his list of steps in the theoretical part of his manual, and yet it seems to be a step he uses in several dances. It is not a step that is used by other dance writers. Guglielmo indicates that "tutti insieme faciano un movimento" at this point in the dance: he does not mention a posa at all, nor does he have the men and women dance separately (Smith 1995, Vol. II, 14).

A note entitled "Che cosa e ballare" found in three manuscripts that contained versions of Guglielmo's manual lists many steps and gives the timing for some of them (Wilson 2003, 10). From this we know that the posa took a quarter of a tempo. This is the only information we have about the posa. The word posa itself, suggests it could have been a "pause" or a "pose" (Wilson 2003, 34). However, by examining other dances, one notes that often a posa is made onto one foot or with one foot. Whichever foot is free at the end of the previous step is the one used to make the

\footnotetext{
${ }^{15}$ All five manuals are thought to be versions of Guglielmo's treatise. See Smith, Fifteenth-Century Dance and Music for information regarding these manuals.
} 
movement. The movement seems to involve placing this free foot on the ground, sometimes in front of the other foot, sometimes beside it (Wilson 2003, 34-35). Wilson suggests that to make this a distinctive move, different from a normal close, it is probable that just the toe would rest on the ground (Wilson 2003, 35).

Both Wilson and Inglehearn ignore the posa in their transcriptions of Anello, and conclude the dance as Cornazano and Guglielmo do, with the men performing a movimento, and then the ladies responding with another.

\subsubsection{Concluding remarks on the difficulty of reconstructing "Anello"}

After having attempted to reconstruct the first of the three choreographies by Domenico that I have selected for my in-depth analysis, I can now say that Domenico's transcription system is not without flaws. For a contemporary reader such as myself, who tries to interpret the instructions five and a half centuries after they were written down, some parts remain ambiguous or unclear. However, it is important to remember that the readership Domenico had in mind would not have encountered the same problems I did. Most likely they would not have had issues with establishing how to perform each step: their extensive physical training with the dance masters in person would have ensured that they knew every term and step-name, thus making it unnecessary for Domenico to clarify these further in his manual.

It is unknown whether the original readers would have been confused as I was by other vague instructions, particularly those concerning which foot to begin with and what the floor pattern was intended to be, or whether these too were standard practices of fifteenth-century court dance and thus deemed common knowledge. By examining two different modern interpretations of Domenico's Anello, I can see how important it is to be very clear when writing dance by giving verbal descriptions. Inglehearn and Wilson's versions of the dance came out so different when I danced them through: different interpretations of the instructions can make it seem like an entirely different dance. Having danced both through, I believe Wilson's version to be more accurate. The formations and floor patterns in his 
interpretation seem both more practical and better fitting with the nature of the title Anello.

The posa remains a mystery. It is strange that no other dance master has written about it in their manuals or included it in their choreographies, or even in their versions of Domenico's choreographies. Perhaps it was a term or a step that had gone out of fashion by the time Domenico's successors wrote their manuals. Unfortunately, as there is no other known evidence of it, we will never know for sure what a posa is unless more dance manuals from the time are discovered.

The dance itself is lovely. With the music in the quadernaria misura, it is lively and upbeat, without being too fast. Unusually, it only has the one misura: almost every other ballo in Domenico's manual has more than one misura in it. Adopting the square formation for most of the routine, it is a good dance to perform in a group, as it feels like a shared event: each individual is dancing for each other, as well as with each other. The call and response sections also add a nice touch of interaction between dancers. Anello is a simple dance, but effective nonetheless, and with all its flaws Domenico's manual allows us to still perform and enjoy it after five and a half centuries.

\subsubsection{The ballo "Lioncello Novo"}

This is a transcription of the "Lioncello Novo" as Domenico wrote it in De arte saltandi et choreas ducendi. ${ }^{16}$

Mprima dicti dui homini cum la dona in mezo fano tempi dui de saltarello in mexura quadernaria e afermase li homini poi la dona se parte de mezo loro cum uno dopio sul pe sinistro e afermase. Li dicti dui homini siegueno poi la dona cun uno dopio andagando equale a lei poi la dona se parte de mezo loro e va inanti cum uno dopio sul pe drito e afermase e li dicti dui ho-

${ }^{16}$ As transcribed by Smith 1995, Vol.1, 30-32. 
mini la siegueno cum uno dopio sul pe drito andagando intorno a quisti dui homini a guisa de uno .S. fazando tempi octo de piva deli quali el quarto e lo octavo se fa im passi dui sempii suso el pe drito e cadauno de dicti dui passi se fanno in mezo de dicti dui homini e afermase poi dicta dona in mezo loro.

Or nota che li homini se parteno tutti dui de compagnia fazando y tempi dui de saltarello comenzando al pe sinistro in mexura quadernaria cum una voltatonda comenzando dal pe sinistro unde gli consiste passi tri sempii e una meza represe afermandose. poi la dona li siegue cum tempi dui de saltarello comenzando dal pe sinistro e quatro pasi sempii dagando in (cho de) dicti quatro passi una mezavolta per ritrovarse guardare al contrario deli homini.

Apresso nota che tutti tri se moveno in uno instante e facendo dupii tri sul pe sinistro et in capo del terzo fano una posada suso el drito in tempo vuodo dagando una mezavolta andagando pero la dona al contrario deli homini cioe loro inanti e lei indrieto ritornando dicti dui homini et dona cum quilli mede(s) mi dicti dupii e posada e ritrovandose la dona in mezo deli homini guardando al contrario loro. Nota che la dona se parte dali homini a roverso di loro fazando uno dopio sul pe sinistro e afermase li dicti dui homini vano inanti cum uno dopio sul pe sinistro e afermanse. La dona va pur ala sua via cum uno dopio sul pe drito e afermase poi li dicti dui homini vano pur ala lor via contrarii dela dona cum uno dopio sul pe drito. Apresso nota che in instanti dicti dui homini e dona danno una mezavolta sul pe drito riguardandose a volto a volto fazando represe due comenzando coll pe sinistro continentie due e riverentia una suso el sinistro afermandose dicti dui homini.

Or nota che la dona se muove e va incontra li homini cum uno dopio sul pe sinistro e afermase poi li homini vano incontra la dona cum uno dopio sul pe sinistro e afermase e la dona vene incontra li homini cum uno dopio sul pe drito e afermase. Li homini vano incontra ala dona cum uno dopio sul pe dri- 
to dagando una mezavolta suso dicto pe e t(r) ovandose havere La dona equale in mezo loro fazando tutti insieme una riverentia sul pe sinistro poi la dona si fa uno movimento de mezo tempo e li homini ge respondeno cum uno altro et e fine.

As with the Anello, this account of Lioncello Novo is written in a rather plain form. It is simply a list of instructions of which steps to perform in which order, with indications of who does each part, where they travel and which foot they begin with. As I will discuss later, a few descriptions are vague or confusing due to lack of detail, but for the most part the instructions are easy to follow. As in the case of Anello, parts that are repeated are not spelled out fully a second time, the dancers are simply instructed to "respondeno cum uno altro" (Smith 1995, Vol.1, 32).

The description of Lioncello Novo is longer than that of Anello, as the dance is both longer and more complex. The language is very similar to that of Anello: all instructions are concise and only include the basic details. It is likely that the title of the dance refers to Leonello d'Este: this dance was perhaps choreographed for him, maybe even for his wedding, as I mentioned in Chapter Two. It is called the Lioncello Novo as it is a newer version of an existing dance, known as the Lioncello Vecchio. The old version was for a couple (a man and a woman), whereas the new version is for three dancers (two men and a woman). The biggest difference between the two versions is thus floor pattern and spacing, due to the differing number of dancers. In both the pattern is quite linear, but in places the new version breaks from this, such as when the woman dances around the men "a guisa de uno .S." (Smith 1995, Vol.1, 30). Both versions are performed to the same tune.

\subsubsection{Problems in reconstructing the Lioncello Novo}

The problems I came across in my attempt to reconstruct Lioncello Novo are quite similar to those I encountered whilst dancing Anello. The biggest issue, once again, was not knowing exactly how to perform each step. Although we can make a fair estimation, we will never know for sure if our reconstructions are accurate, as there is no other known evidence. 
As with the Anello, some descriptions in Domenico's phrasing of Lioncello Novo are confusing, leaving some instructions unclear and some floor patterns ambiguous. One problem I found with the Lioncello that I had not encountered with the Anello has to do with the timing of some steps and how they fit in with the music, as I will discuss shortly.

\section{Problem 1: Domenico does not explain how to perform the steps}

I will not revisit the steps which I have already discussed in relation to Anello. Unless specified, such steps would be performed in the same manner as in the previous dance. The steps that do not appear in Anello are danced as follows:

Doppio: ${ }^{17}$ A "double" step, called as such in England and other Western European countries for centuries prior to Domenico's work. The name seems to imply the performance of two simples on the same foot. When linking two simples together like this, issues arise on the nature of the connection between the two. Is it purely step close, step close, or does the second step become more of a travelling step now that the two simples are connected? And if this is the case, is it a small step forward, more similar to the close of a simple, or does the second step become the same size as the first and third, in order to travel further?

Musically speaking, a doppio takes one tempo (two bars). Cornazano instructs his readers to "undulate" (ondeggiare) on the second step of a doppio, which he says is shorter than the others (in the saltarello misura at least, and probably other triple time measures) (Smith 1995, Vol. I, 86-7). In a duple-time measure, this long-shortlong rhythm probably did not appear, as it would not fit properly with the music.

It is unknown whether the doppio is supposed to finish in a closed or an open position. There is evidence to support both theories, so it is difficult to know for sure. In his description of Belfiore, Guglielmo instructs the dancer to close his feet

\footnotetext{
${ }^{17}$ Unless otherwise referenced, discussion of this step is based on Wilson's The Steps Used in Court Dancing in Fifteenth-Century Italy 17-24.
} 
at the end of a particular doppio (Smith 1995, Vol. I, 167), which seems to imply this was not the standard practice, but a variation on a normal step. In this case, the standard doppio would be seen as finished in an open position. On the other hand, in some of Domenico's dances, doppi seem to be performed continuously on the same foot, as it appears in section four of Lioncello Novo. According to Wilson, this suggests that one must close the feet at the end of a doppio, otherwise it cannot be repeated on the same foot.

Sempii: ${ }^{18}$ Sempio means "single", but it is usually found in its plural form sempii, as it is here. This is chiefly due to the fact that a sempio takes up only half a tempo, so it is often performed in pairs. Inglehearn describes it as a step performed on a rise, then a close and a lowering of the heels (Inglehearn 1981, 7). This seems a reasonable assumption. Like the doppio, sempii appear to be performed on alternating feet in most dances, but on some occasions the wording is such as of the doppi described above (that is, "on the left foot"), suggesting that the same foot is to be used each time.

As with the doppio, the manuals of the Renaissance dance masters do not specify whether the sempio should finish in a closed or open position, but either might be possible. Obviously, if the sempii are to be performed on the same foot, the dancers must close their feet at the end of each one. However, if they are alternating, it is easier to leave them open, although it is possible to close in this case too, as Inglehearn suggests (Inglehearn 1981, 7).

A sempio is generally performed forward of the body, whether the instruction is to turn it, or move straight ahead. Wilson points out that on very rare occasions, the dance masters could instruct the dancer to perform a sempio travelling backwards, but such an instruction does not appear in Lioncello novo (Wilson 2003, 50).

\footnotetext{
${ }^{18}$ Unless otherwise referenced, discussion of this step is based on Wilson's The Steps Used in Court Dancing in Fifteenth-Century Italy 48-53.
} 
Sometimes a sempio could take less than half a tempo of music. Lioncello novo is thusly called because there was an older version of the same dance, performed to the same music, also incorporated in Domenico's manual. Where the new dance has two tempi of saltarello and a voltatonda consisting of three sempi and a mezaripresa, the older version has four sempi and one doppio. In order for the rest of the dance to fit with the music, the voltatonda of the new version must take no longer than one tempo, which would make each of the sempi and the mezaripresa only a quarter of a tempo.

Meza ripresa: Mezza means "half", in this case referring to the timing of the step. The step itself is to be performed as described above, but in half the time of a normal ripresa (Wilson 2003, 38).

Posada: As mentioned in the description of Anello, this was an alternative term for posa.

Continenza: ${ }^{19}$ This step is very similar to the ripresa, but more modest in performance, as the name suggests. A continenza is a step to the side like the ripresa, but smaller. Continenze were usually performed in pairs, one to the left followed by one to the right. In Domenico's manual, continenze were only performed in bassadanze, or in bassadanza sections of balli. In all but one of the bassadanze, continenze are used to begin the dance. Two continenze followed by a riverenza are found on more than one occasion in Domenico's dances. This is how they appear in Lioncello Novo.

Riverenza: ${ }^{20}$ This was often the step used to begin or end a dance throughout Renaissance Europe. It was like a curtsey or a bow, like the one used in modern dance as a sign of respect, or to honour someone. A riverenza is made "onto" one foot but the weight is not transferred, as the same foot is then used to perform the

\footnotetext{
${ }^{19}$ Discussion of this step is based on Wilson's The Steps Used in Court Dancing in Fifteenth-Century Italy 11-15.

${ }^{20}$ Discussion of this step is based on Wilson's The Steps Used in Court Dancing in Fifteenth-Century Italy 41-44.
} 
next step. Sometimes the dance masters would specify that it should be made "in terra", with the knee going right down to the ground. This suggests that a normal riverenza, as performed in Lioncello Novo, would be danced with a bent back knee, reaching partway towards the ground.

\section{Problem 2: Floor pattern}

For the Lioncello Novo, Domenico makes very clear some parts of the floor pattern, such as the piva steps that travel in the ' $\mathrm{S}$ ' shape that is performed by the lady around the men, with the two sempi in between the sets of piva danced directly between the men. Other parts are not so clear. Once again we do not find indications as to where the initial saltarelli are to be travelled. In her interpretation of this dance, Inglehearn has the dancers perform them turning, but this seems to me to be her own addition (Inglehearn 1981, 20). In many of her reconstructions, Inglehearn appears to have taken interpretive liberties, as will become more evident in the discussions of Lioncello Novo and Gelosia. As only two saltarelli are performed in Domenico's choreography, it is most likely that they would be executed straight ahead, although Inglehearn's turn adds an elegant variation.

The most ambiguous part of the dance in regards to the floor pattern is the instruction for all dancers to repeat the doppi and posada, with the men facing the woman, finishing on an equal level, but facing opposite ways. Inglehearn interprets this as the men curving their path slightly on both the original and the returning set, so that they end up facing both each other and the woman (Inglehearn 1981, 21). I have illustrated Inglehearn's interpretation below:

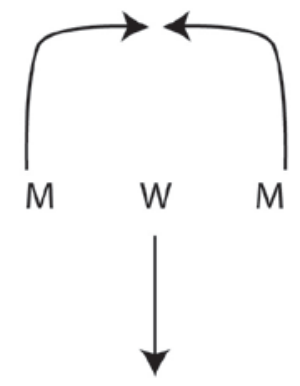

Original Set

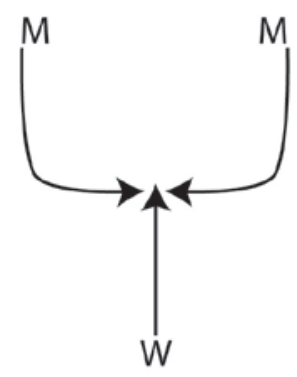

Returning Set 
I can see how Inglehearn interpreted it this way, but I think it could also be reconstructed as follows:

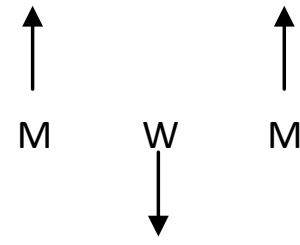

Original Set

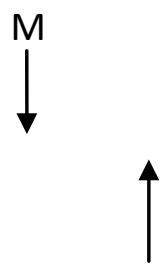

W

Returning Set

Inglehearn has obviously interpreted the instruction "ritrovandose la dona in mezo deli homini guardando al contrario loro" as an indication that the men should be facing each other, but it could just as well mean the men and the woman are facing opposite ways. It seems more likely to me that the latter, more linear design is what Domenico intended, as the rest of the dance follows patterns more similar to this.

\subsubsection{Concluding remarks on the difficulty of reconstructing the "Lioncello Novo"} Lioncello novo is a more complex dance than Anello. It has a wider variety of steps and involves several changes of misure. The choreography seems less playful and more regal in the Lioncello, which is consistent with the fact that the dance may be named after Leonello d'Este.

Aside from the main issue of not knowing exactly how to perform each step, I had fewer problems in trying to reconstruct Lioncello novo than I did for the Anello. The floor pattern discrepancies were once again a problem, and for a second time I feel Inglehearn's interpretation is creative rather than faithful to Domenico's intention. However, the floor pattern issue does not seem as problematic in this dance, as I did not feel that Inglehearn's version made for a completely different dance as it did in the case of Anello.

I did encounter two other problems in reconstructing the Lioncello Novo, but they were minor ones, which did not hinder my overall reconstruction of the dance to a 
great degree. I found the instruction to do "tempi octo de piva/deli quali el quarto e lo octavo se fa im passi dui sempii suso el pe/drito" strangely worded. The most logical interpretation is to assume that two sempi are performed instead of a normal piva step in the place of what would otherwise be the fourth and eighth piva step. The combination will now be three piva steps followed by two sempii, and then repeated.

The other minor problem I had was with the timing of some steps. As discussed in the section about the sempio, the sempi in the voltatonda must be shorter than normal sempi, taking up a quarter of a tempo instead of half, in order for the steps to fit in with the music. The three sempi thus take up three quarters of a tempo, leaving only one quarter remaining for the mezaripresa, which would also normally take up half a tempo (Wilson 1999, 113). Domenico does not mention anything about these steps being shorter in length than normal, but it seems they must have been, otherwise they would not fit with the music. My deductions for the correct timing for these problematic steps, as with the description of the piva, are reasonable conclusions to come to, not hindering the accuracy of the reconstruction.

Ultimately, although technically a more challenging dance, Lioncello novo was easier to reconstruct than Anello, as I found Domenico's instructions for this ballo were clearer, meaning that there was less room for interpretation.

\subsubsection{The ballo "Gelosia"}

This is a transcription of the "Gelosia" as Domenico wrote it in De arte saltandi et choreas ducendi. ${ }^{21}$

\section{La giloxia in canto}

Giloxia a balo e va in siei zoe homeni tri e done tre. Mprima se pigliano homo uno et una dona per man tuti siei

${ }^{21}$ As transcribed by Smith 1995, Vol.1, 34-36 
in thiope tre. E fano tienpi siei de saltarelo largi in mexura quadernaria chomenzando dal pe sinistro e afermanse intendandosse che vagino l'una thi(o) pa driedo al' altra e largi per spathio de pasi tri. Ora nota che lo homo che se trova denanti lasa la dona soa fazando dupii tri suxo el pe sinistro in mexura quadernaria andagando denanti via ala soa dona e va a tochare la man ala dona de mezo cun una riverientia suxo el pe sinistro e afermase.

Lo homo che e apreso la dita dona de meço fa uno tenpo di saltarelo in mexura quadernaria partandose cun lo pe drito e va appreso la prima dona e li se aferma.

Apreso nota che lo homo che e de meço a lato la man drita dela dona si se parte e pasa denanti ala dita dona cun dupii tri suxo el pe sinistro in mexura quadernaria ritrovandose el dito homo apreso la dona de driedo e tochando gie la man drita cun una riverienthia e afermasse.

Ora nota che lo homo che havea per man la dita dona de driedo fa tenpo uno de saltarelo in mexura quadernaria chomençando cun lo pe drito et andagando (equale ala dona de mezo ala man sua stanca l'homo che se ritrova apresso la dona de drieto va) drieto ale spale dela dona de drieto ritrovandose essere ge equale ala mane sua stanca cun lo saltarelo predito. Ancora nota che tutti homini e done se moveno fazando tempi octo de piva l'una chiopa drieto al' altra per ordine e fermanose le due chiope de drieto fazando el primo homo cum la prima dona mezavolta suso lo lato sinistro in uno tempo de piva e fermaseno. La segonda chiopa gli responde fazando el simele e poi la terza risponde ala segonda facendo el simele e fermase.

Or nota che cadauno de tutti li homini se ritrova guardare nel volto ala sua dona e la dona a lui pigliandose cadauna de loro chiope per la mane drita fazando passi tri sempii comenzando cum lo pe drito e scambiando posta poi se lassano per la mane drita pigliandose per la sinistrs fazando passi tris empii comenzando 
cum lo pe sinistro ritrovandose ale poste loro e dagando li homini una mezavolta suso el pe sinistro pigliando le done per mano. fiz Nota che l'homo primo che era denanti nel principio de dicta danza se ritrova drieto nela fine e quello che era de drieto se ritrova in mezo e quello de mezo se ritrova denanti Siche l'e necesso che dicta danza se façi volte tre vogliando che cadanno deli homini habino el dover suo.

Gelosia is a ballo for six dancers: three men and three women, who begin dancing as three couples. Throughout the dance the men flit between the different women, leaving their original partner to dance with another lady. By the end of the routine, each man has returned to his original partner. The dance is a very clear representation of the theme of the dance, jealousy, as indicated by the title. Each man circles around another's lady, touching hands with her and forcing the man whose lady he has now taken to move onto another.

The choreography is playful, with circling both around one's partner and around the room a dominant feature. There is much more interaction between dancers in this ballo than there was in the Lioncello Novo. Written in the quadernaria misura it is a reasonably upbeat dance, suitable for the playful choreography. It could be called a repetitive dance, as the whole routine is performed three times before it is considered finished, in order for each man to end with his original partner.

Lingustically speaking, Domenico's transcription of the Gelosia is more detailed than both the Anello and the Lioncello Novo. This is because there are more additional details necessary to make the instructions clear. Rather than just being able to give the step name, direction of travel and beginning foot, Domenico needs to explain which man dances around which lady. Unlike the previous two dances, where he could simply specify which gender was to perform each part, in Gelosia many sequences are performed by individuals so it is necessary to provide details of which dancer is to perform which sequence. There are also additional details given about hands: neither of the previous dances indicated what the arms were 
supposed to do, but in the Gelosia there are instructions throughout to hold hands, touch hands or take hands.

The Gelosia was a very popular dance, recorded in eight of the nine manuals that have survived from the Renaissance period (Wilson 1999, 82-83). As a dance for more people (six was quite a large number of dancers for Domenico), who get to dance with each member individually instead of just one's own partner, it was probably more enjoyable than other dances. The fact it has a storyline demonstrated through its interactive choreography probably contributed to make it popular. Some variants occur in other versions of the Gelosia, mostly regarding step sequences, but also the number of dancers: some manuals increase the number of dancers to eight or ten (Wilson 1999, 83). However, these variants do not change the nature of the dance overall.

\subsubsection{Problems in reconstructing the "Gelosia"}

Once again the major obstacle in reconstructing the routine is that Domenico does not explain how to perform the steps he lists in his description of Gelosia. Having already examined all of the steps that appear in Gelosia in my discussions of the Anello and the Lioncello Novo, I will not address them here, preferring to focus on the floor patterns.

As the floor pattern is more complex than those of the other balli I have examined so far, Domenico has taken more time to ensure his instructions are clear. He is much more specific in the description of Gelosia, carefully explaining which of the six dancers is to perform each part. With every step he has listed, he has written which foot to begin with, so there is no discrepancy in the reconstructions this time.

In general, I had fewer problems trying to reconstruct Gelosia than both the other dances. Additionally, I think the problems I did find are all quite minor and do not really affect the possibility of performing the dance. 


\section{Problem 1: The opening saltarelli}

Domenico instructs his reader to do six "saltarelo largi" to open the ballo. However, when I tried this with the music the phrase had not yet finished and it did not feel right to move on to the next section. I turned to Guglielmo and Cornazano's versions of the Gelosia and found that both these dance masters had instructed their readers to perform eight saltarelli instead of six. It seems that the tune must have been adjusted later to accommodate for the additional two saltarelli. As I could only find versions of the tune that allow for eight saltarelli, my reconstruction will stray slightly from Domenico's instructions and will feature the two additional steps.

The word "largi" that follows "saltarelo" in Domenico's instruction is also interesting to look at. In his translation of the Gelosia, Smith writes the dancers are to perform six tempi of "wide saltarello", whereas Wilson writes "slow saltarello". These two words have different implications. To me, "wide" is referring to step size, meaning either the steps are bigger than normal, or the foot is placed slightly wider than usual, not directly in front of the body. "Slow" obviously means the steps are performed at a reduced speed. This could be why Domenico has the dancers perform six saltarelli, while Cornazano and Guglielmo state there should be eight: maybe Domenico's are supposed to be danced through the music, while his followers preferred to perform them in time with the music? It is difficult to know for sure what Domenico intended by the term largi.

\section{Problem 2: Different interpretations of the floor pattern}

Once again, Inglehearn has interpreted the instructions regarding the floor pattern in a different manner than I would (Inglehearn 1981, 25). The main difference in her interpretation is that she has presumed that after the initial saltarelli the men and the women face each other for the remainder of the dance. However there is no written instruction in the description of Gelosia to indicate this. The fact that the word "apreso" is used to indicate where the man should finish suggests he should go next to the lady rather than face her. Moreover, towards the end of the routine 
"tutti li homini se ritrova guardare neL volto ala sua dona". To me this is an indication that up to this point in the routine they had not been facing each other.

This changes the dance quite noticeably. Wilson does not comment on the floor pattern of the dance, so by examining his and Smith's translations of Domenico's ballo, I have come to my own conclusions. In my interpretation of the section after the initial saltarelli, the leading man (M1) should move like this, ending next to the second woman (W2):

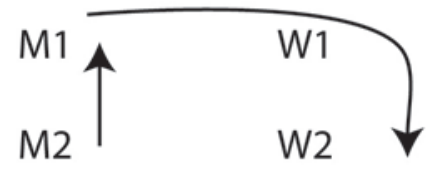

M3 W3

However, in Inglehearn's version, this is how it appears, with M1 ending in the place of the second male dancer (M2) who in the meantime has moved up into M1's starting position:

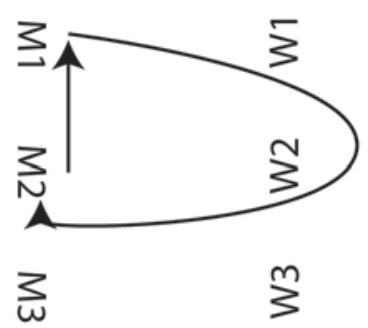

The next section is thus also affected. The man now in the middle (M1) is supposed to pass in front of the woman next to him (W2) and end up next to the lady at the back of the formation (W3):

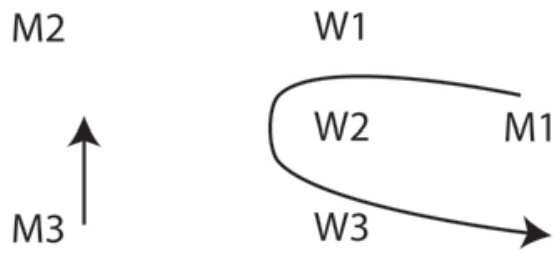

My interpretation 
By contrast, for Inglehearn the man in the middle (M1) passes between W2 and W3 and ends facing the lady at the back of the formation (W3):

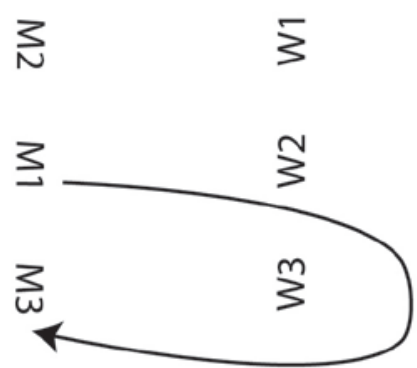

Inglehearn's interpretation

The next instruction, for the third man who was at the back (M3) to move forward and the leading man now at the back (M1) to go behind the third lady (W3), should be performed like this:

$\begin{array}{ll}\text { M2 } & \text { W1 } \\ \text { M3 } & \text { W2 }\end{array}$

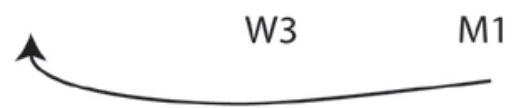

My interpretation

Instead, Inglehearn instructs M1 to do two slow pive back "around the $3^{\text {rd }}$ lady to end between the $2^{\text {nd }}$ and $3^{\text {rd }}$ ladies" (Inglehearn 1981, 25):

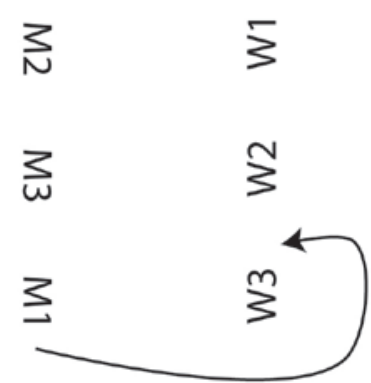

Inglehearn's interpretation 
The pive are also different. In Wilson's transcription, there are eight tempi of pive to be performed. Inglehearn instructs her readers to do only four, with the women going round in a circle, and the men in another. The transcription then says that each couple (one pair at a time) performs a mezavolta. Because she has the dancers facing a different way, Inglehearn here says to perform a full turn on the spot so that they can face each other again at the end of the turn.

For the final section of the dance, my interpretation and Inglehearn's are the same. At this point Domenico instructs the men to "guardare nel volto ala sua dona", touch right hands with the lady opposite him and perform three sempi changing places with her, and then three more returning to his position.

Although I have classified this issue of floor pattern as a problem, after examining the transcript of the Gelosia and Inglehearn's interpretation, I am happy that my interpretation is more faithful to Domenico's text. Inglehearn's version of the Gelosia seems a free interpretation, incorporating some of her own ideas, rather than a true reconstruction of the initial choreography. Looking back at the Anello and the Lioncello Novo, it is apparent she has provided creative interpretations of these dances too, so perhaps she has put a modern twist on all her reconstructions of fifteenth-century dances.

\subsubsection{Concluding remarks on the difficulty in reconstructing the "Gelosia"}

The Gelosia is a very enjoyable dance. It has much more of a sense of character than the Anello and the Lioncello Novo. Living up to its name, the dancers take turn at making each other jealous by moving in on another man's partner and dancing with her. This means that every man gets to dance with every lady, something which does not happen often in the Renaissance repertoire.

I found Domenico's instructions for the Gelosia clearer than those for the Anello and the Lioncello Novo. He has taken better care in his description of the specific floor pattern and which foot to use, making the dance much easier to reconstruct. 
Inglehearn's version of the Gelosia turned out different to mine when I danced them both through. However I feel that this is due to artistic interpretation on her part, rather than ambiguous descriptions given by Domenico.

\subsection{General conclusions}

At the start of this chapter I set out to reconstruct some of Domenico's choreography in order to establish how effective his methods of dance description were, how well they have endured the test of time and whether they were clear enough to be still performed. I chose three contrasting balli, the Anello, the Lioncello Novo and the Gelosia, in the hope of providing a fair assessment of his writing style. I found his style to be short and concise with no unnecessary detail, no embellished descriptions and no imagery or references to other works to get his point across. By creating a technical vocabulary for his style of dance, Domenico was able to write almost in shorthand, simply naming each step, which foot to begin with and which direction to travel in.

For a modern day reader such as myself, this is challenging as it means none of the steps are described in detail so we have to deduce how they may have been performed. However, for a fifteenth-century courtier this would have been an ideal way to remember choreographies and practise them. Some other problems I came across in my attempts to reconstruct the balli might also be due to the fact that I am reading the instructions five and a half centuries after they were written. It could have been a standard practice, for example, for every step to start on the left foot (as most seem to), thereby explaining why Domenico did not always state which foot to use: he may have assumed his reader would know it was the left. Unfortunately none of the dance masters write about this anywhere, so it is impossible to know if this was the case or not.

I have found that the more complex Domenico's choreography is, the more time he has spent on ensuring his instructions were clear. Anello, choreographically speaking is a very simple dance, yet of the three it was the most difficult to reconstruct due to some ambiguous instructions. Gelosia involves more complex 
patterns and figures and so Domenico has taken care to be more specific with his instructions.

As a dance notation system, word descriptions seem to be an effective method of recording dance. If the writer is as specific as he or she can be, dances notated in this system can be reconstructed by any dancer who reads it, providing that they have a previous knowledge of the style of dance, as dance descriptions are shorthanded by naming the steps rather than describing every movement in every step in full detail. The dancer must thus be fluent in the vocabulary of each particular style of dance in order to be able to reconstruct any given written notation. For Domenico's readers, this meant they had to know what a sempio or a saltarello was. Likewise, for a reader of a ballet routine today the dancer must know what a pirouette is and a tap dancer must know what a shuffle involves.

Therefore, for a fully codified style of dance, Domenico's method is suitable and practical, but for freestyle contemporary routines that can incorporate any form of movement it might prove difficult to adopt. The dance writer would have to provide full details of how to perform each movement in any given sequence which would lead to a very long and detailed dance description. In this style of dance, a symbolbased system that shows what each part of the body should be doing may prove easier to use. In Domenico's situation however, in fifteenth-century Italy where all court members knew the repertoire of steps, his method of written descriptions was ideal. 


\section{Conclusion: from textual analysis to performance}

There seems to be a pattern in the Western cultural tradition which links the preservation of the arts to the development of high culture. Once any art form reaches a certain status within the higher levels of society of the time, there emerges a need to intellectualize it, notate it and discuss it in written form. For a long period of time reading and writing were skills only members of the upper classes were taught: thus, they were able to write down the stories that had previously been passed down orally, creating literature in its written form as we know it today. Theatre and drama, although remaining performance-based, developed a written component, with scripts preserving the texts and often offering performance instructions. Music notation was created as music theory was developed addressing a need for an intellectual written aspect to its performance. It was also a way to ensure consistent and precise preservation of tunes, as they could change over time if only passed down orally or aurally. Other arts, such as painting, sculpture and film were easier to preserve from their very beginnings as they have always involved a visual element that is easily accessible and exists more often permanently, unlike other visual arts. Each of those arts has been intellectualized without great controversy and therefore has been preserved throughout Western culture. By contrast, dance, an ephemeral art, seems to be most difficult to preserve. After a piece has been performed it is often forgotten, as teachers and choreographers traditionally did not pass down their choreography in a notated form.

The need to write down dance has been identified and addressed by many people throughout history. Around 85 systems have been created in one form or another (Guest 1984, xi), yet none of them have been accepted by enough people to become widely understood and used like music notation is. The desire to understand dance intellectually, to preserve it in writing as well as in performance became permanent later than it did for many other art forms. Up until the fifteenth century dance was something that was taught by oral instruction and physical 
demonstration only. This is owed to the fact that up until then dance was largely the domain of popular culture. It was an activity that the masses could partake in, often outdoors for festivals, rituals or other celebrations. When dance shifted from a popular activity to a component of everyday life for the aristocracy in fifteenthcentury Italy, Domenico da Piacenza saw the need to preserve and teach dance in a form additional to the traditional physical and oral method.

Inspired by the manuals written by the humanist thinkers of the Italian Renaissance that were widely spreading among the dominant classes and intellectuals at the time, Domenico wrote his own manual with dance as its subject, providing rules for technique and advice on how to dance to different types of music, as well as twenty-three of his own choreographies. By writing De arte saltandi et choreas ducendi Domenico tried to make dance an art rather than just an everyday practice. By composing routines and notating them in his manual he created choreography that he could claim authorship of. With set routines, as opposed to the improvisational dances of popular culture, dance gained more status as an art, as it also became a performance-based practice rather than a ritualistic or celebratory practice.

As discussed in Chapter Two, Domenico's target readership was mainly formed of Renaissance courtiers, for whom dancing was part of everyday life. For them, his manual became a tool to help them practise choreographies and perfect technique, as every courtier was expected to dance with grace within the court and at special occasions or festive events. Domenico was writing for people who were already familiar with his style of dance. The manual was probably created for his patron at the time, but it was read by other students also, in particular Cornazano and Guglielmo who went on to become dance masters in their own right. The manuals these two dance masters wrote in 1455 and 1463 are so similar in style to Domenico's that they show the author's familiarity with his manual.

Due to the fact that his readership was familiar with the style of dance already, Domenico was able to describe his dances in a simplified manner, by giving only the 
name of each step, rather than a full description of the movement involved. To do this, his style of dance had to be fully codified, and a technical vocabulary had to be created in order for steps and techniques to be instantly recognisable. Some of the terms Domenico uses in his manual to describe techniques appear to be his own creations, like fantasmata, but in other circumstances he employs terms from everyday life and from other arts, such as aere, misure and maniera, as I have discussed in Chapter Three. The terms used for step names seem to be descriptive of the movement itself: a saltarello, for example, involves a small hop and a volta tonda involves a full turn. Although these step names may not all have been created by Domenico himself, he was the first person to write them down and associate them forever to specific dance movements. Domenico's originality thus lies not only in his role as a dance master, but as a dance writer too. As the first person to write down dance in a systematic way, he set a precedent for the codification of dance styles to come, such as ballet and ballroom, for which the creation of their own vocabulary, technique books and written choreographies would develop in a manner very similar to Domenico's.

In my personal attempt to reconstruct some of Domenico's choreographies, I came across a few problems other than the lack of clarity in understanding how the steps should be performed, which I brought to attention in Chapter Four. Mostly these were to do with ambiguous instructions regarding floor patterns, which made it difficult to know for sure where Domenico intended each dancer to travel. In reconstructing Anello, Lioncello Novo and Gelosia, I noticed that the more complex Domenico's choreography and floor pattern was, the more care he had taken with the details of his instructions, and therefore the easier the dance was to reconstruct.

Domenico's manual De arte saltandi et choreas ducendi would have been a very useful tool for fifteenth-century Italian courtiers, who would already have had an understanding of the dance style, and have been taught steps and routines in person by Domenico or another maestro di ballo. For a modern reader such as myself, Domenico's manual is not as easily understood. Most of the steps Domenico used five and a half centuries ago are not still used in dance today, and if 
they are they do not share the same names. This means that Domenico's shorthand system of simply naming steps rather than describing them, makes a reconstructor's job difficult as one has to make an educated guess based on other sources and practices as to how each step should be performed. Domenico's method is therefore highly effective for those already familiar with the style of dance, but difficult for those without prior understanding.

Domenico's method of notating dance with word descriptions was used by other notable dance writers later in history, particularly in the codification of classical ballet technique. As briefly mentioned in Chapter Three, Carlo Blasis was the first person to codify ballet in written form in his work titled Traité élémentaire, théorique, et pratique de l'art de la danse, published in 1820. In this book he provided illustrations and word descriptions in order for readers to perfect their technique (Franko 2011, 325).

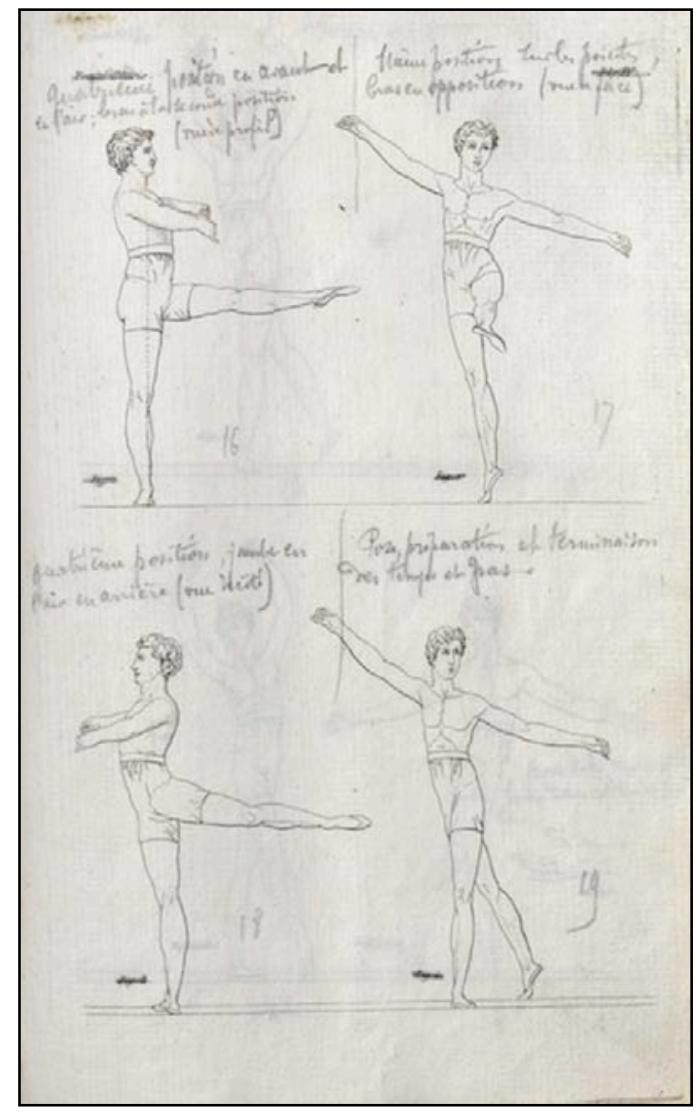

Fig 19: Illustrations from Carlo Blasis' Traité élémentaire, théorique, et pratique de l'art de la danse, 1820. 
Many after Blasis have written manuals on classical ballet technique and its repertoire of movements is so fully codified that any ballet dancer should be able to learn exercises or routines by reading the names of the steps involved. Tembeck points out that ballet choreography is "limited to re-arranging well-known steps" (Tembeck 1981/82, 72). Domenico's style of dance was much the same: his choreographies were also different arrangements of the same steps, steps which every dancer of the time knew the name of and how to perform.

It is because these styles of dance are so fully codified that the method of notating dance by providing word descriptions, sometimes accompanied by pictorial depictions and more recently, photos, seems to work so well. It is a quick and easy way for a choreographer/teacher to notate a dance, and an accessible way for a dancer familiar with the vocabulary of the style of dance to read it. This is why it is still the most popular way to record dance five and a half centuries after Domenico first codified it. If one picks up a syllabus for exam work in ballet, tap, jazz, latin, ballroom or several other dance styles these days, one would still see the exercises notated in written form with specialist names describing steps and techniques.

Although Domenico's method of dance writing works effectively and efficiently for these highly codified styles such as court dance and ballet, there are problems with using his method for styles such as contemporary and modern dance. This is due to the fact that these more recent steps and choreographies have not been fully codified: in contemporary dance any body movement can be used so it is almost impossible to write and name them all. In some cases, word descriptions can become lengthy or ambiguous as some movements prove very difficult to describe in words. As Marina Nordera points out, it is possible that Domenico himself came across movements that were too difficult to write and so he left them out of his manual, but we will never know this for certain (Nordera 2007, 28).

For uncodified styles of dance such as contemporary or jazz, symbol-based systems like Labanotation or the Benesh Movement notation may be more useful than word descriptions. With these systems the symbols can portray unnamed steps in a less 
ambiguous manner, with each symbol representing the part of the body which is to be used, and how and where a dancer should move. This way it is not necessary to try and put a non-traditional physical movement into words. Schools such as Juilliard in New York use Labanotation to preserve their pieces (Guest 2004, 96) and the founders of modern dance were known to have used this system also. Today we have access to more than twenty works of the well-known American modern dance founder and choreographer Doris Humphrey, as they were preserved through Labanotation (Siegel 2004, 404).

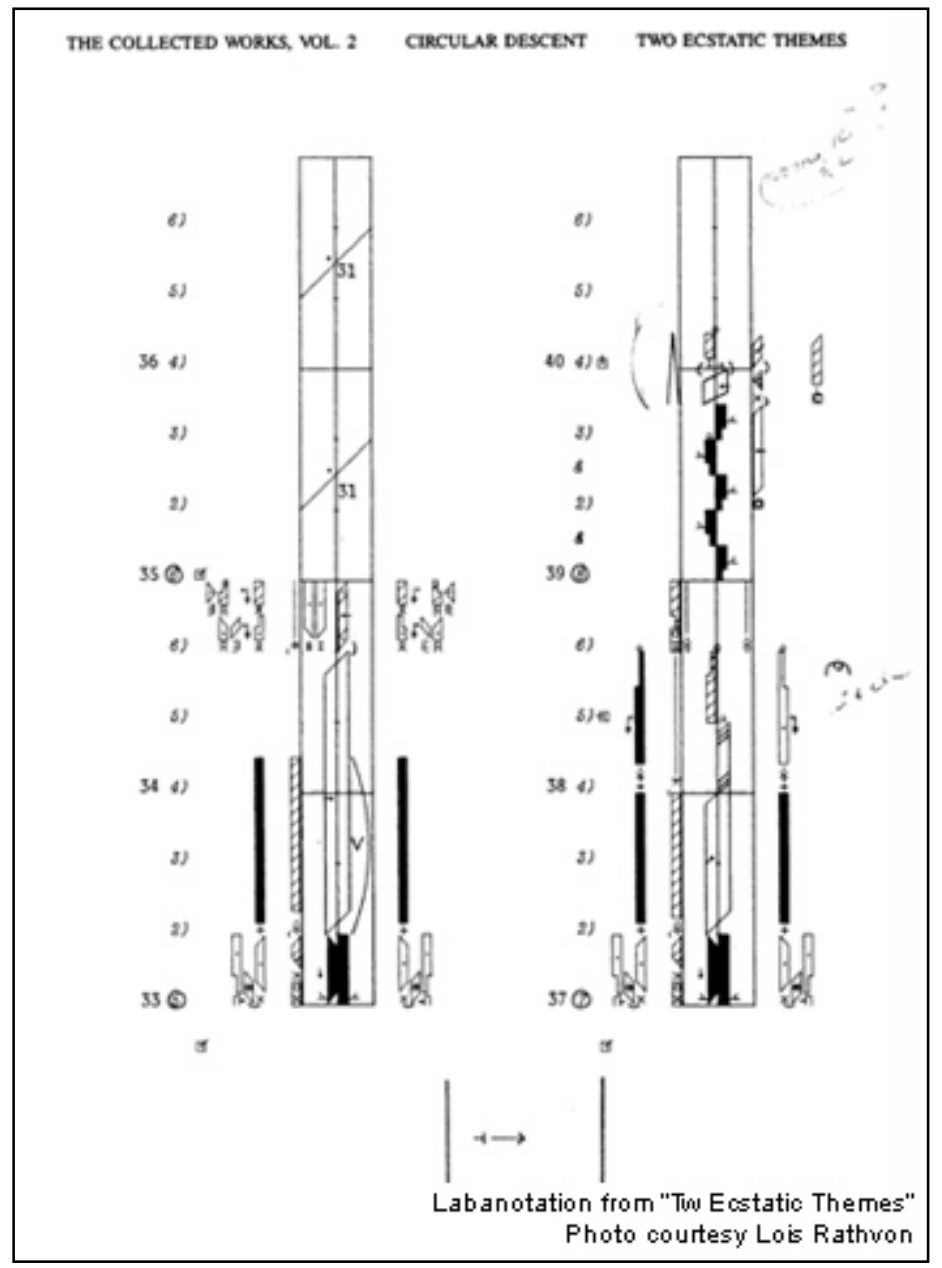

Fig 20: Part of the Labanotation for Doris Humphrey's work "Two Ecstatic Themes".

Dance notation can also be helpful for recording theatrical dance. Hanya Holm was the first person to have a full theatrical work notated in Labanotation when her choreography for the 1948 Tony-Award winning musical Kiss Me, Kate was notated. This choreography was copyrighted in 1952, and as such, was the first 
choreography to be granted this title in the United States of America (Randall 2012, $3)$.

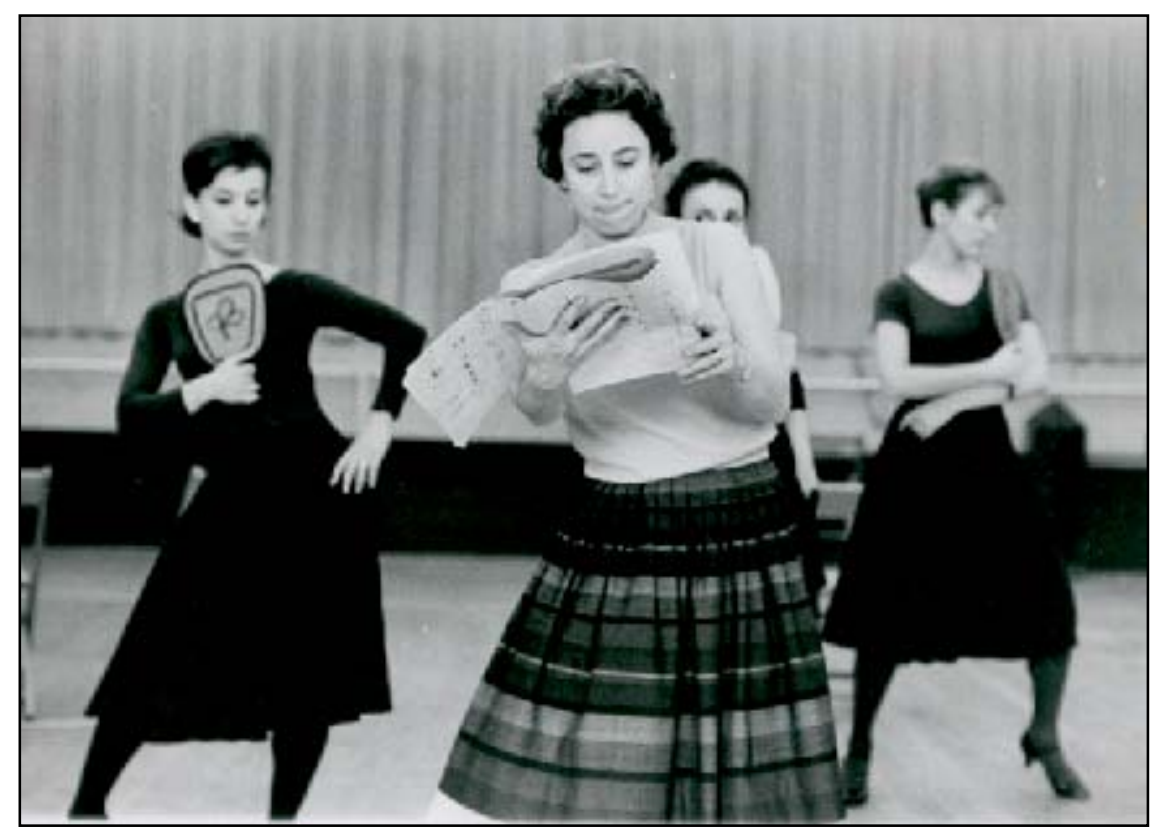

Fig 21: A photograph of a rehearsal of Broadway show Kiss Me, Kate. The dancer in front reads from the Labanotation score.

Guest writes of the four main requirements a good dance notation system must address:

a) Unusual timing (abnormally slow or fast) for common, familiar actions;

b) isolated movement of a part of the body (hand, foot, knee, etc.), which normally does not move in isolation, or special emphasis placed on a part (elbow, shoulder, hip, etc.);

c) variation in spatial pattern: a design or pathway which is 'larger (or smaller) than life', or body shapes related to known poses but performed with sufficient modification to cause them to depart from the norm;

d) Unusual quality of movement: exaggerated strength, smoothness, limpness, heightened tenseness, etc. (Guest 1984, 20).

Any of these aspects can be described through the use of words, but to varying degrees of difficulty. If a step is unusual, complex or long it can result in a lengthy and possibly ambiguous description. As I discovered through reconstructing Domenico's work, the more specific the instructions are, the clearer they are to 
follow. However, to write down all the specific details of an unusual movement may result in a long description for a very short/small movement.

Although dance notation in any of its forms is a great idea, it is important to remember that dance is something that cannot be studied from a book only. Anyone can try and understand a style of dance, or try and recreate choreographies from text whether it is a sequence of words or a series of symbols, but it is not really dance until it is physically performed. Nordera points out that for dancers “non si impara a danzare dalla scrittura, ma dall'osservazione attiva e imitativa di un corpo danzante, sia esso di un maestro o di qualcuno che già conosce quella forma di danza" (Nordera 2007, 25). Although De arte saltandi et choreas ducendi was probably created as a teaching tool, it was not intended to be the only instruction available to a dancer. The presence of a teacher who could show steps and movements in the first instance was also essential, as it still is today. This is true of other arts such as music and drama too, but to a lesser extent. A music teacher is necessary to teach a student music theory and how to actually play the instrument, but after this is established any music student can pick up some sheet music and teach themselves a particular song. Drama can be self-taught, as actors are generally capable of picking up a script and learning their lines from it. A director or an acting coach may be used though to make a character more believable, to suggest blocking or to help with accents or general articulation of words. Thus it seems the more established and accessible a writing system is, and the more reliant on it an art is, the less the presence of a teacher is necessary. As dance notation is traditionally the least developed, or the least practised, it is the art that most needs a teacher's presence to be fully understood.

Dance notation, in particular Domenico's style of word description, is therefore most effective as a memory-jogging tool. It is a way for dancers to remember routines and exercises after having been taught them in person, or a way for choreographers to preserve their pieces, claim their authorship. Domenico's manual was the perfect companion to lessons in person with him: his pupils could 
use it to remind themselves of routines, or brush up on the theory behind the style of dance by reading the sixteen chapters on technique.

This is not to say that Domenico's manual cannot be used by anyone today as they cannot be taught in person by a Renaissance dance master. Anyone that does research into the style of dance can attempt to recreate his choreographies, as I have done myself. My efforts can be viewed by watching the DVD attached in the appendix. It is not an easy process: it takes time, determination and the use of other sources. The first action in trying to reconstruct any given dance is the knowledge of how to perform the steps involved in the choreography. As Domenico does not describe in detail how to perform any of the steps, it was necessary for me to look into the manuals of his disciples Guglielmo and Cornazano for hints, and then into the secondary research done by D.R. Wilson and Madeleine Inglehearn on how they thought the Renaissance steps should be performed. As I have mentioned earlier, the presence of a teacher helps immensely in learning any steps or choreography and I am grateful to Jennifer Shennan for the background she has given me in Renaissance dance through teaching me some choreography of Domenico and his followers in her Dances in History paper at Victoria University in 2007 and in additional community classes since then. This meant that I had previous knowledge of some of Domenico's steps and had danced the Anello routine before, which was extremely helpful in my reconstruction of not only that dance, but also of the Lioncello Novo and the Gelosia, neither of which I had danced before.

There were still a few steps such as the posa that I had no idea how to perform. As I mentioned in Chapter Four, Inglehearn does not talk about it at all and Wilson writes that the posa is a mystery to him as Domenico seems to be the only dance writer to mention it and does so without explaining what it is. As a minor step which is not used very often, it did not hinder my reconstructions to a great degree.

Once I had determined how to perform the steps I had to figure out what Domenico intended the floor pattern to be and therefore where each step should be travelled. 
This is difficult for one person to do trying to figure out where three or four or six dancers should be, as one cannot be in all places at once. Drawing the diagrams that I discussed in Chapter Four helped me with this part of the reconstruction as it became a visual way for me to work out where each dancer should be without having to physically dance through each individual's part.

After drawing my diagrams and confirming the floor pattern for the routines, it was necessary to dance through the steps in Domenico's given order to the music to make sure they all fit. This meant I had to find music to dance to. As I do not have access to musicians who can read and play Renaissance music on the relevant instruments, I had to find recorded versions of each tune. Fortunately, this did not prove as difficult as I had imagined, as I found a recording of each tune on iTunes. Because Domenico and his followers also included music notation with their dances, as I discussed in Chapter Two, dance history has been an interest of musicians and musicologists as much as it has dance historians. Therefore, all of the tunes in Domenico's manual have been recorded by musicians and are now easily accessible.

Once I felt sure I had the steps right and confirmed they fit with the music, the next step was to find other dancers who would help me recreate Domenico's choreographies by playing out the floor patterns, particularly as Inglehearn had interpreted Domenico's instructions so differently to myself and to Wilson. I therefore wanted to dance through her interpretation of the dance as well as my own, in order to have a visual representation of the differences and decide which version seemed more likely to be the one that Domenico had intended. One of the many ways that society is very different today from fifteenth-century Italy is the fact that dance is not a part of everyday life for the majority of people, so I had to be careful who I chose. I wanted people who had a background in dance already, so they would pick up the choreography quickly and who would not get confused by dancing through two different versions of the same dance. As a dance teacher, the easiest way for me to do this was by asking some of my senior dancers to help me out. As I have no senior male students in my class I asked female dancers to play the male roles in Domenico's choreographies. 
The next challenge was trying to fit the dance into the hall where I teach my classes. The ballrooms of Renaissance Italy were much bigger, particularly in length, than any hall I could find to use, so some steps had to be danced quite small in order to fit the entire sequence in the space available. There was a further issue with this when it came to filming the dances, as the floor pattern had to be made more compact in order to fit everybody on camera. This was particularly a problem in the Lioncello Novo when the lady moves in a different direction to the men: the video could not capture both ends of the room at once so we had to make sure there was less distance between us than Domenico had intended in order for all parties to be caught on camera.

Although I did run into some challenges in the reconstruction process, the fact that I was able to do it at all is a tribute to Domenico, his initiative to write down dance, and his skill in doing so. It is definitely possible to recreate his choreographies and those of his fellow dance masters. By reading their manuals and doing some additional research into how the steps were performed, anyone with a keen interest in Renaissance dance should be able to dance through Domenico's choreography.

It is indeed fortunate that Domenico decided to write down his routines and inspired others to do so too, because now we have access to styles of dance, fashions, trends and numerous routines popular throughout history that would have otherwise been lost. It is extraordinary to think that we can still attempt to reconstruct Domenico's choreography five and a half centuries after he wrote it down. If more dance teachers had thought to write down their thoughts on technique and their choreographies then we may not have lost so many great works of art, such as the moresche performances of the professional Renaissance dancers, or the legendary ballets choreographed by stars such as Vaslav Nijinsky. 


\section{Bibliography}

Adshead-Landsdale, Janet and June Layson. Dance History, an Introduction. London: Routledge, 1994.

Anderson, Jack. Dance. New York: Newsweek Books, 1974.

Brainard, Ingrid. "Bassedanse." Cohen, Selma Jeanne. The International Encyclopedia of Dance. New York and Oxford: Oxford University Press, 2004a. Vol. 1. 378-382.

Brainard, Ingrid. "Dancing Master." Cohen, Selma Jeanne. The International Encyclopedia of Dance. New York and Oxford: Oxford University Press, 2004b. Vol. 2. 336-341.

Brainard, Ingrid. "Domenico da Piacenza." Cohen, Selma Jeanne. The International Encyclopedia of Dance. New York and Oxford: Oxford University Press, 2004c. Vol. 2. 427-429.

Brinson, Peter and Peggy Van Bragh. The Choreographic Art - An Outline of its Principles \& Craft. London: A\&C Black Ltd, 1963.

Carter, Curtis L. "Aesthetics: Western Dance Aesthetics." Cohen, Selma Jeanne. The International Encyclopedia of Dance. New York and Oxford: Oxford University Press, 2004. Vol. 1. 19-26.

Caroso, Fabritio. Nobiltà di dame (1600). A Treatise on Courtly Dance Translated and Edited by Julia Sutton. Oxford, New York: Oxford University Press, 1986.

Castiglione, Baldesar, ed. Giulio Preti. Il libro del cortegiano. Torino: Giulio Einaudi, 1960.

Celi, Claudia. "Dance Research and Publication." Cohen, Selma Jeanne. The International Encyclopedia of Dance. New York and Oxford: Oxford University Press, 2004a. Vol. 3. 553-558.

Celi, Claudia. "Dance Traditions before 1800." Cohen, Selma Jeanne. The International Encyclopedia of Dance. New York and Oxford: Oxford University Press, 2004b. Vol 3. 540-547.

Crisp, Clement and Mary Clarke. The History of Dance. New York: Crown Publishers, Inc., 1981.

Fermor, Sharon. "On the Question of Pictorial 'Evidence' for Fifteenth-Century Dance Technique. Dance Reasearch: The Journal of the Society for Dance Research, Vol. 5, No. 2, (1987): 18-32. 
Franko, Mark. "Writing for the Body". Common Knowledge, Vol.17, No. 2 (2011): 321-334.

Gombosi, Otto. "About Dance and Dance Music in the Late Middle Ages". The Musical Quarterly, Vol.27, No.3 (1941): 289-305.

Guest, Ann Hutchinson. Dance Notation - The Process of Recording Movement on Paper. London: Dance Books Ltd, 1984.

Guest, Ann Hutchinson. "Dance Notation." Perspecta. Theater, Theatricality, and Architecture, Vol.26 (1990): 203-214.

Guest, Ann Hutchinson. "Labanotation". Cohen, Selma Jeanne. The International Encyclopedia of Dance. New York and Oxford: Oxford University Press, 2004. Vol. 4. 95-98.

Herbison-Evans. "Dance, Video, Notation and Computers". Leonardo, Vol. 21, No.1 (1988): 45-50.

Inglehearn, Madeleine. 15th Century Dances from Burgandy and Italy. Essex: The Companie of Dansers, 1981.

Lockwood, Lewis. Music in Renaissance Ferrara 1400-1505. Oxford: Clarendon Press, 1984.

Nevile, Jennifer. The Eloquent Body - Dance and Humanist Culture in FifteenthCentury Italy. Bloomington: Indiana University Press, 2004.

Nordera, Marina. "Modelli e processi di trasmissione del sapere coreutico: i manuali quattrocenteschi tra oralità e scrittura". Danza, cultura e società nel Rinascimento italiano. A cura di Eugenia Casini Ropa e Francesca Bortoletti. Macerata: Ephemeria Editrice, 2007. 23-32.

Pontremoli, Alessandro. La Storia della Danza. Firenze: Casa Editrice Le Lettere, 2009.

Pontremoli, Alessandro and Patrizia La Rocca. I/ ballare lombardo. Milano: Vita e Pensiero, 1987.

Randall, Tresa. "Hanya Holm (1893-1992)". Dance Heritage Coalition, (2012): 1-3. http://www.danceheritage.org/treasures/holm_essay_randall.pdf (last accessed on $30 / 10 / 12$ ).

Siegel, Marcia B. "Doris Humphrey". Cohen, Selma Jeanne. The International Encyclopedia of Dance. New York and Oxford: Oxford University Press, 2004. Vol 3. 397-405. 
Smith, A. William. Fifteenth Century Dance and Music Vol.1. New York: Pendragon Press, 1995.

Smith, A. William. Fifteenth Century Dance and Music Vol.2. New York: Pendragon Press, 1995.

Sorrell, Walter. Dance in its Time - The Emergence of an Art Form. New York: Anchor Press/Doubleday, 1981.

Sparti, Barbara. "15th Century Balli Tunes." Early Music, Vol. 14, No. 3 (1986): 346357.

Sparti, Barbara. "Antiquity as Inspiration in the Renaissance of Dance: The Classical Connection and Fifteenth-Century Italian Dance." Dance Chronicle, Vol.16, No. 3 (1993): 373-390.

Sparti, Barbara. "Breaking Down Barriers." Dance Chronicle, Vol. 19, No.3 (1996a): 255-276.

Sparti, Barbara. "The Function and Status of Dance in the Fifteenth-Century Italian Courts." Dance Research: The Journal of the Society for Dance Research, Vol. 14, No. 1 (1996b): 42-61.

Sparti, Barbara. "La danza come politica al tempo di Machiavelli". Lingua e le lingue di Machiavelli. Atti del Convegno internazionale di studi, Torino, 2-4 dicembre 1999: Firenze: L. S. Olschki, 2001. 295-313.

Sparti, Barbara and Janet Adshead-Lansdale. "Dance History: Current Methodologies". Dance Research Journal, Vol. 28, No. 1 (1996): 3-6.

Sutton, Julia. "Ballo and Balletto." Cohen, Selma Jeanne. The International Encyclopedia of Dance. New York and Oxford: Oxford University Press, 2004. Vol. 1. 351-355.

Tembeck, Iro. "The Written Language of Dance or Preserving Dance on Paper". SubStance, Issue 33-34 (1981/1982): 66-83.

Veroli, Patrizia and Barbara Sparti. "Dance Research in Italy." Dance Research Journal, Vol. 27, No. 2 (1995): 73-77.

Wilson, D. R. Sources for Early Dance - 1. Domenico da Piacenza. Revised Ed. Cambridge: Victoire Press Ltd, 2006.

Wilson, D.R. The Steps Used in Court Dancing in Fifteenth-Century Italy. Cambridge: Published by the Author, 2003. 
Wilson, David. 101 Italian Dances (c.1450-c.1510). A critical translation. Cambridge: Victoire Press Ltd, 1999.

\section{Websites Used for Illustrations:}

Avaxhome. Thoinot Arbeau - L'Orchesographie

http://avaxhome.ws/ebooks/others/thoinot_arbeau_-_orchesographie.html; (last acessed 2/4/12).

Ballet Dance Magazine. http://www.ballet-

dance.com/200607/articles/Rathvon20060324.html; (Last accessed 24/4/12).

Ballet Wonderland. "Caroso: The Rose Pattern".

http://teresaleedesign.com/balletwonderland/floorplans_1.html; (last accessed 2/4/12).

Balletto.net. "grand maestri: Ebreo".

http://www.balletto.net/giornale.php?articolo=1034; (last accessed 26/6/11).

Bibliore. "Basse danse with Attitude I". http://bibliolore.org/2010/07/04/bassedanse-with-attitude/; (last accessed 26/6/11].

Britannica Mobile Edition. http://m.eb.com/assembly/71979; (last accessed 2/4/12].

Compagnia.http://www.compagniadeiviandanti.it/images/Approfondimenti/De\%2 0arte\%20saltandi\%20et\%20choreas\%20ducendi.png; (last accessed 28/8/11).

Dance Magazine. "Kiss Me Kate on Broadway Made Copyright History." http://www.dancemagazine.com/blogs/admin-admin/4463; (last accessed 26/10/12).

Early Dance Circle. http://www.earlydancecircle.co.uk/three.html; (last accessed 9/9/11).

J. Willard Marriott Library. The University of Utah. "Dramatis Personae". http://www.lib.utah.edu/collections/rarebooks/exhibits/past/dramatispersonae.php; (last accessed 17/11/12).

Labanotation - basic Symbols. http://ajijo.co.uk/labanot.html; (last accessed 2/4/12).

My Daily Art Display. "The Effect of Good Government on City and Country. Ambrogio Lorenzetti." http://mydailyartdisplay.wordpress.com/2011/02/13/effectof-good-government-on-city-and-count; (last accessed 26/6/11). 
The National Library of Russia. Facsmile Reprints.

http://www.nlr.ru/eng/coll/music/facs.html?print=1; (last accessed 27/3/12).

Onensemble. "Book reviews: Dance Notation".

http://onensemble.org/2010/08/book-reviews-dance-notation/; (last accessed 2/4/12].

Proceedings of the Known World Dance Symposium 2007. "Survey of European Dance Sources 1400-1700. Peter and Janelle Durham.

http://www.peterdur.us/kwds2007/proceedings/Survey-of-European-DanceSources.htm; (last accessed 2/4/12).

Wikipedia. "Labanotation."

http://en.wikipedia.org/wiki/Laban_Movement_Analysis; (last accessed 2/4/12]. 
Appendix: DVD of balli in performance 